\title{
Application of WRF/Chem-MADRID and WRF/Polyphemus in Europe - Part 1: Model description, evaluation of meteorological predictions, and aerosol-meteorology interactions
}

\author{
Y. Zhang ${ }^{1}$, K. Sartelet ${ }^{2}$, S.-Y. Wu ${ }^{3}$, and C. Seigneur ${ }^{2}$ \\ ${ }^{1}$ Department of Marine, Earth, and Atmospheric Sciences, North Carolina State University, Raleigh, NC 27695, USA \\ ${ }^{2}$ CEREA (Atmospheric Environment Center), Joint Laboratory École des Ponts ParisTech and EDF R\&D, Université \\ Paris-Est, 77455 Marne-la-Vallée, France \\ ${ }^{3}$ Department of Air Quality and Environmental Management, Clark County, NV, USA
}

Correspondence to: Y. Zhang (yang_zhang@ @ ncsu.edu)

Received: 12 December 2012 - Published in Atmos. Chem. Phys. Discuss.: 14 February 2013

Revised: 15 May 2013 - Accepted: 21 May 2013 - Published: 22 July 2013

\begin{abstract}
Comprehensive model evaluation and comparison of two 3-D air quality modeling systems (i.e., the Weather Research and Forecast model (WRF)/Polyphemus and WRF with chemistry and the Model of Aerosol Dynamics, Reaction, Ionization, and Dissolution (MADRID) (WRF/ChemMADRID)) are conducted over Western Europe. Part 1 describes the background information for the model comparison and simulation design, the application of WRF for January and July 2001 over triple-nested domains in Western Europe at three horizontal grid resolutions: $0.5^{\circ}, 0.125^{\circ}$, and $0.025^{\circ}$, and the effect of aerosol/meteorology interactions on meteorological predictions. Nine simulated meteorological variables (i.e., downward shortwave and longwave radiation fluxes (SWDOWN and LWDOWN), outgoing longwave radiation flux (OLR), temperature at $2 \mathrm{~m}$ (T2), specific humidity at $2 \mathrm{~m}(\mathrm{Q} 2)$, relative humidity at $2 \mathrm{~m}(\mathrm{RH} 2)$, wind speed at $10 \mathrm{~m}$ (WS10), wind direction at $10 \mathrm{~m}$ (WD10), and precipitation (Precip)) are evaluated using available observations in terms of spatial distribution, domainwide daily and site-specific hourly variations, and domainwide performance statistics. The vertical profiles of temperature, dew points, and wind speed/direction are also evaluated using sounding data. WRF demonstrates its capability in capturing diurnal/seasonal variations and spatial gradients and vertical profiles of major meteorological variables. While the domainwide performance of LWDOWN, OLR, T2, Q2, and RH2 at all three grid resolutions is satisfactory overall, large positive or negative biases occur in SWDOWN, WS10, and Precip
\end{abstract}

even at $0.125^{\circ}$ or $0.025^{\circ}$ in both months and in WD10 in January. In addition, discrepancies between simulations and observations exist in T2, Q2, WS10, and Precip at mountain/high altitude sites and large urban center sites in both months, in particular, during snow events or thunderstorms. These results indicate the model's difficulty in capturing meteorological variables in complex terrain and subgrid-scale meteorological phenomena, due to inaccuracies in model initialization parameterization (e.g., lack of soil temperature and moisture nudging), limitations in the physical parameterizations (e.g., shortwave radiation, cloud microphysics, cumulus parameterizations, and ice nucleation treatments) as well as limitations in surface heat and moisture budget parameterizations (e.g., snow-related processes, subgridscale surface roughness elements, and urban canopy/heat island treatments and $\mathrm{CO}_{2}$ domes). While the use of finer grid resolutions of $0.125^{\circ}$ and $0.025^{\circ}$ shows some improvements for WS10, WD10, Precip, and some mesoscale events (e.g., strong forced convection and heavy precipitation), it does not significantly improve the overall statistical performance for all meteorological variables except for Precip. The WRF/Chem simulations with and without aerosols show that aerosols lead to reduced net shortwave radiation fluxes, $2 \mathrm{~m}$ temperature, $10 \mathrm{~m}$ wind speed, planetary boundary layer (PBL) height, and precipitation and increase aerosol optical depth, cloud condensation nuclei, cloud optical depth, and cloud droplet number concentrations over most of the domain. These results indicate a need to further improve the 
model representations of the above parameterizations as well as aerosol-meteorology interactions at all scales.

\section{Introduction}

Significant progress in Europe has been made in recent years in reducing air pollution and its harmful impact on public health through monitoring air pollutants, tightening air quality standards, controlling emissions of air pollutants, and communicating with various stakeholders and the general public on the preventive measures of reducing air pollution and exposure. Several studies showed a strong association between adverse effects on human health (e.g., daily mortality, lung and heart diseases, and diabetes) and elevated $\mathrm{PM}_{2.5}$ levels in European cities (e.g., Helsinki and Stockholm) (e.g., Timonen et al., 2004; Rosenthal et al., 2011; Aphekom, 2011; Meister et al., 2012). Coarse particles are also associated with increased morbidity and hospital admissions of people with respiratory diseases (Brunekreef and Forsberg, 2005; Pope and Dockery, 2006), despite their less detrimental health effects. Regulations for air quality in Europe focus on gaseous pollutants (e.g., $\mathrm{O}_{3}, \mathrm{NO}_{2}, \mathrm{SO}_{2}$ ) and particulate matter with aerodynamic diameters less than or equal to 2.5 and $10 \mu \mathrm{m}\left(\mathrm{PM}_{2.5}\right.$ and $\left.\mathrm{PM}_{10}\right)$ (European Commission, 2008). Anthropogenic sources such as traffic, energy consumption, industry, domestic combustion and agriculture are the major sources of these pollutants in continental Europe (EMEP, 2006a, b; WHO, 2006), although longrange transport also plays an important role in some regions (e.g., southern Europe where $\mathrm{PM}_{10}$ concentrations may be enhanced by mineral dust particles transported from the Sahara desert) (Escudero et al., 2007; Stohl et al., 2007; Kallos et al., 2007, 2009; Jiménez-Guerrero et al., 2008; Spyrou et al., 2010). Air quality models (AQMs) are used to understand why high concentrations are sometimes observed and to assess the effects of proposed emission reductions on air quality standards in Europe. To establish confidence in these models, they are validated by comparison of model results with observations from ground networks, ground-based lidars, and satellites. For example, over Europe, different AQMs such as Polyphemus, CHIMERE, the European Monitoring and Evaluation Programme model (EMEP), the LOng Term Ozone Simulation (LOTOS), and the Community Multiscale Air Quality (CMAQ) modeling system have often been used to simulate past episodes or forecast European air quality (see references for each model in Solazzo, 2012a). Most of these models were intercompared during the Air Quality Model Evaluation International Initiative (AQMEII) project (Galmarini et al., 2010; Rao et al., 2011; Solazzo, 2012a, b). Regional AQMs have also been used in conjunction with urban/local traffic and/or dispersion models to assess the impact of European emission control on urban/local air quality (e.g., Giannouli et al., 2011).
Depending on the coupling between a meteorological model (MetM) and a chemical transport model (CTM), current three-dimensional (3-D) AQMs can be grouped into two types: offline and online. In the offline-coupled AQMs, a MetM is used first to generate the meteorological fields; a CTM is then used to generate chemical concentrations using outputs from the MetM. The chemical concentrations from the CTM are not fed back to the MetM. In the online-coupled AQMs, simulations using the MetM and CTM are performed in parallel, exchanging predicted meteorological and chemical fields at every time step. Such an online-coupled AQM may include two models with an interactive interface in between such as two-way coupled WRF/CMAQ (Yu et al., 2011; Wong et al., 2012) (which is also referred to as an online access model) or one unified model system in which meteorology and air quality variables are simulated together in one time step without an interface between the two models such as the Weather Research and Forecast model with Chemistry (WRF/Chem) (which is also referred to as an online integration model) (Grell et al., 2005; Fast et al., 2006; Zhang, 2008; Zhang et al., 2010a; Kukkonen et al., 2011; Baklanov et al., 2013). The model treatments of atmospheric processes for both chemical and meteorological variables are consistent in the online integration models but may be different in the online access models. These online models can therefore simulate not only pollutant concentrations but also the meteorology-chemistry feedbacks through various direct, semi-direct, and indirect feedback mechanisms. Both offline and online models have their own merits and are commonly used in current regional and global models. Offline AQMs are frequently used in ensembles and operational forecasting, inverse/adjoint modeling, and sensitivity simulations, whereas online-coupled AQMs are increasingly used worldwide for cases with important chemistrymeteorology feedbacks (e.g., climate change investigations) and fast changes in the local-scale wind and circulation system (Zhang, 2008). The online-coupled AQMs have been applied over many regions including North America (Jacobson et al., 1996, 1997; Grell et al., 2005; Zhang, 2008; Zhang et al., 2010a, b, 2012a), Asia (Tie et al., 2009; Wang et al., 2010; Zhang et al., 2012b; Jiang et al., 2012), and Europe (Baklanov et al., 2007, 2008; Zhang et al., 2011a; Forkel et al., 2012; Tuccella et al., 2012), as well as on a global scale (Roeckner et al., 2006), and global through urban scales (Jacobson, 2001; Zhang et al., 2012c). The strengths and limitations of offline- and online-coupled models are summarized in several reviews (e.g., Grell et al., 2004; Zhang, 2008; Baklanov, 2010; Baklanov et al., 2011, 2013; Kukkonen et al., 2011), among which Zhang (2008) reviewed several onlinecoupled models used over North America and Kukkonen et al. (2011) and Baklanov et al. (2013) provided a comprehensive review of online-coupled models used over Europe. A comprehensive review of offline- and online-coupled AQMs for real-time air quality forecasting models can be found in Zhang et al. (2012d, e). 
The performances of offline- and online-coupled AQMs have been compared in several studies. For example, San José et al. (2009) compared offline-coupled Fifth-Generation Penn State/NCAR Mesoscale Model (MM5)/CMAQ and online-coupled WRF/Chem for a high particulate matter (PM) episode over Germany in winter and found that WRF/Chem gave better agreement with PM observations. Matsui et al. (2009) compared WRF/CMAQ v4.6 and WRF/Chem v2.2 over Beijing, China, and found that WRF/Chem systematically gave higher overpredictions of the surface concentrations of primary species such as carbon monoxide $(\mathrm{CO})$, nitrogen oxides $\left(\mathrm{NO}_{\mathrm{x}}\right)$, and elemental carbon (EC) due to different treatments of mixing processes. Yu et al. (2011) and Wong et al. (2012) compared offline- and online-coupled WRF/CMAQ and reported improved model performance in surface shortwave and longwave radiation, $2 \mathrm{~m}$ temperatures, the shortwave and longwave cloud forcing, surface ozone $\left(\mathrm{O}_{3}\right)$ and $\mathrm{PM}_{2.5}$.

This study aims at comparing two AQMs: an offlinecoupled model (i.e., WRF/Polyphemus), and an onlinecoupled model (i.e., the WRF with chemistry and the Model of Aerosol Dynamics, Reaction, Ionization, and Dissolution (MADRID), referred to as WRF/Chem-MADRID) to assess their capabilities in simulating pollutant concentrations over Europe, and the importance of including the feedbacks between aerosols and meteorology for air quality simulations. Compared with a previous application of Polyphemus over Europe in 2001 that used MM5 as the MetM (Sartelet et al., 2007), this study uses WRF as the MetM and an updated version of Polyphemus, includes a much more comprehensive model evaluation with a number of surface networks and satellites, and intercompares the predictions of WRF/Polyphemus and WRF/Chem-MADRID at different grid resolutions. Compared with recent applications of WRF/Chem over Europe, the aerosol module MADRID used in this work includes secondary organic aerosol (SOA) formation that was not included in the study of San José et al. (2009) and that differs from the simpler SOA model SORGAM used by Tuccella et al. (2012) and Forkel et al. (2012). It also includes the aerosol-cloud-precipitation feedbacks that were not included in San José et al. (2009) and Tuccella et al. (2012). In addition, this work examines the sensitivity of predictions to horizontal grid resolution and biogenic emissions that were not addressed in previous WRF/Chem applications over Europe.

The results from this study will be presented as a sequence of two parts. Part 1 describes the two modeling systems: WRF/Polyphemus and WRF/Chem-MADRID, their configurations and the simulation setup, evaluation protocols and observational databases used, the evaluation of meteorological predictions and sensitivity to horizontal grid resolutions using WRF, and the effect of aerosol/meteorology interactions on meteorological fields using WRF/Chem-MADRID. Part 2 (Zhang et al., 2013) describes the evaluation for chemical concentrations and intercomparisons between chemical predictions from the two models, sensitivity of the model predictions to horizontal grid resolutions, and the effect of interactions between meteorology and aerosols predicted with WRF/Chem-MADRID on air pollutant concentrations.

\section{Model descriptions and simulation design}

\subsection{WRF/Chem-MADRID and WRF/Polyphemus}

Table 1 summarizes inputs and treatments of major atmospheric processes in the two AQMs used in this study. WRF/Chem-MADRID is based on publicly released WRF/Chem version 3.0 and offers two additional gas-phase mechanisms (i.e., CB05 and SAPRC99) and one additional aerosol module (MADRID) that are alternatives to default gas-phase mechanisms and aerosol modules. A detailed description can be found in Zhang et al. (2010a, 2012a). WRF/Chem-MADRID has been applied to eastern Texas in the US to simulate PM and its interactions with meteorology with different gas/particle mass transfer approaches (Zhang et al., 2010a), to the eastern US to forecast realtime air quality (Chuang et al., 2011), and to the continental US (CONUS) to simulate surface $\mathrm{O}_{3}$ and PM concentrations and aerosol feedbacks using different gas-phase mechanisms (Zhang et al., 2012a) and different aerosol modules (Zhu et al., 2011). The air quality modeling platform Polyphemus with the CTM Polair3D has been widely used for modeling pollution buildup and transport on urban to continental scales (e.g., Sartelet et al., 2008, 2012; Royer et al., 2011), and specifically to simulate the year 2001 over Europe (Sartelet et al., 2007). A detailed model description setup of Polair3d/Polyphemus is given by Sartelet et al. (2007). Compared with the study of Sartelet et al. (2007), major updates in the model treatments include the gas-phase chemistry, the calculation of photolysis rates, the treatment of organic aerosols, the number of vertical levels and the land use cover.

To minimize differences in model predictions, the same or similar modules are chosen for both model simulations whenever possible. For example, both models use the same gas-phase chemical mechanism (CB05) (Yarwood et al., 2005), the same photolysis scheme (Fast-J) (Wild et al., 2000), and the same aqueous-phase chemical mechanism that is based on the Carnegie Mellon University (CMU) aqueous-phase chemistry of Fahey and Pandis (2001). Although Polyphemus/Polair3D is an offline CTM, photolysis rates are computed online, and thus the influence of particles on photolysis rates is taken into account (Real and Sartelet, 2011). The major differences between the two AQMs lie in heterogeneous chemistry, dry and wet deposition of gaseous and aerosol species, aerosol treatments, and aerosol-cloud interactions. While the version of WRF/Chem-MADRID used in this study does not treat heterogeneous chemistry, Polyphemus includes heterogeneous reactions of $\mathrm{HO}_{2}, \mathrm{NO}_{3}$ 
and $\mathrm{N}_{2} \mathrm{O}_{5}$ on the surface of aqueous particles and cloud droplets based on Jacob (2000). Polyphemus uses the SIze REsolved Aerosol Model (SIREAM)-SuperSorgam aerosol module (Kim et al., 2011), and WRF/Chem-MADRID uses the MADRID aerosol module of Zhang et al. (2010a, 2012a). Although both aerosol models use a sectional size representation with 8 sections between 0.0215 and $10 \mu \mathrm{m}$ and simulate aerosol thermodynamics using ISORROPIA (Nenes et al., 1998) for inorganic species, dynamic processes (nucleation, coagulation and condensation/evaporation) and organic aerosol thermodynamics, they differ in several aspects. Both models include similar sets of SOA precursors (e.g., aromatics, long-chain alkanes, long-chain alkenes, isoprene, and terpenes), and use an absorptive approach for hydrophobic SOA (Super-Sorgam of Kim et al. (2011) for Polyphemus - an updated version of the MADRID 1 SOA module for WRF/Chem-MADRID). However, the Super-Sorgam SOA module in Polyphemus accounts for the $\mathrm{NO}_{\mathrm{x}}$ dependency for SOA formation from biogenic substances and aromatic compounds based on $\mathrm{Ng}$ et al. (2007) that is not treated in the MADRID SOA module. WRF/Chem-MADRID simulates the homogeneous binary nucleation of sulfuric acid $\left(\mathrm{H}_{2} \mathrm{SO}_{4}\right)$ and water vapor $\left(\mathrm{H}_{2} \mathrm{O}\right)$ based on the approach of McMurry and Friedlander (1979) that accounts for the competition between nucleation and condensation. Although SIREAM in Polyphemus may be used with two different parameterizations for nucleation, nucleation is not taken into account in this work. For gas/particle mass transfer, both models use the bulk equilibrium approach in this work. In Polyphemus, for inorganic compounds, the weighting scheme used to redistribute the total particle equilibrium concentrations between the particles of different sizes (sections) depends on the condensation/evaporation kernel of the condensation/evaporation rate (Debry et al., 2007). In WRF-Chem, the redistribution of transferred mass also depends on the condensational growth law (Zhang et al., 2004). A further difference between the two models lies in the sea-salt components (sodium and chloride), which are included in WRF/ChemMADRID but not included in the equilibrium calculation in Polyphemus despite their inclusion in the PM composition.

The dry and wet deposition treatments used in the two models are different. WRF/Chem-MADRID calculates the dry deposition fluxes of gases based on the surface resistance of Wesely (1989), whereas Polyphemus uses a surface resistance parameterization that is similar to that of Wesely (1989) but with updated treatments of Zhang et al. (2003) that consider non-stomatal resistance for all depositing gases. Zhang et al. (2003) compared observed dry deposition velocities of $\mathrm{O}_{3}$ and $\mathrm{SO}_{2}$ calculated with and without considering nonstomatal resistance (e.g., in-canopy aerodynamic, soil and cuticle resistances) and found that the calculated dry deposition velocities with non-stomatal resistance over wet canopy are much higher by about a factor of two than those without non-stomatal resistance, and the former agreed better with observations and thus provided a more realistic treat- ment of cuticle and ground resistance. For dry deposition of PM, the modules used in both models calculate particle dry deposition velocities as a function of particle size and density and relevant meteorological variables, but using different modules. WRF/Chem-MADRID uses the parameterization of Venkatram and Pleim (1999). Compared to the traditional approach that is based on electrical analogy, this parameterization conserves mass because it accounts for the fact that the resistance component depends on a concentration gradient, whereas the sedimentation term does not. Polyphemus uses the parameterization of Zhang et al. (2001) that treats dry deposition processes, such as turbulent transfer, Brownian diffusion, impaction, interception, gravitational settling, and particle rebound. Despite the use of different modules (Easter et al. (2004) for WRF/ChemMADRID and Sportisse and Dubois (2002) for Polyphemus), both models include similar treatments for belowcloud scavenging of gases and use effective Henry's law constant for major water-soluble gases. WRF/Chem-MADRID considers additional in-cloud scavenging of gases that is not treated in Polyphemus. WRF/Chem-MADRID treats in- and below-cloud wet removal of PM based on the parameterization of Easter et al. (2004). Polyphemus only treats in-cloud scavenging parameterization of PM based on the parameterization of Roselle and Binkowski (1999). For aerosol-cloud interactions, WRF/Chem-MADRID includes an aerosol activation parameterization of Abdul-Razzak and Ghan (A-R \& G) (2002) and simulates aerosol direct, semi-direct, and indirect effects. Polyphemus allows the activation of particles if they exceed a critical diameter of $0.7 \mu \mathrm{m}$ (Strader et al., 1998) but does not simulate aerosol direct, semi-direct, and indirect effects (other than the aerosol feedbacks into photolysis rates). These differences in model treatments together with other differences (e.g., advection and chemical boundary conditions) will affect chemical concentrations simulated with both models.

\subsection{Simulation design}

Both models use the meteorological fields produced by WRF with an online coupling for WRF/Chem but an offline coupling for Polyphemus. The physics options selected for the WRF simulations are summarized in Table 2 . Figure 1 shows the triple-nested simulation domains. The level 1 domain (D01) covers Western Europe $\left(35^{\circ} \mathrm{N}-\right.$ $\left.70^{\circ} \mathrm{N}, 15^{\circ} \mathrm{W}-35^{\circ} \mathrm{E}\right)$ with a horizontal grid resolution of $0.5^{\circ} \times 0.5^{\circ}$. The level-2 domain (D02) covers France, Germany, the Netherlands, Belgium, Switzerland, Luxembourg, Slovenia, most of Austria, and parts of the UK, Italy, the Czech Republic, Spain, Croatia, and Poland $\left(41.8125^{\circ} \mathrm{N}-\right.$ $\left.54.8125^{\circ} \mathrm{N}, 6.1875^{\circ} \mathrm{W}-15.7825^{\circ} \mathrm{E}\right)$ with a horizontal grid resolution of $0.125^{\circ} \times 0.125^{\circ}$. The level-3 domain (D03) covers the greater Paris region in France $\left(48.1375^{\circ} \mathrm{N}-49.5125\right.$ ${ }^{\circ} \mathrm{N}, 1.3875^{\circ} \mathrm{E}-4.1375^{\circ} \mathrm{E}$ ) with a horizontal grid resolution of $0.025^{\circ} \times 0.025^{\circ}$. The WRF simulations are performed 
Table 1. Model configurations and major atmospheric process treatments in WRF/Chem and Polyphemus.

\begin{tabular}{|c|c|c|}
\hline Attribute & WRF/Chem-MADRID & Polyphemus \\
\hline Horizontal resolution & $\begin{array}{l}0.5^{\circ} \text { over D01 }(100 \times 70), 0.125^{\circ} \text { over D02 }(176 \times 104) \text {, } \\
\text { and } 0.025^{\circ} \text { over D03 }(90 \times 50)\end{array}$ & Same as WRF/Chem-MADRID \\
\hline Vertical resolution & $\begin{array}{l}23 \text { layers from } 1000 \text { to } 100 \mathrm{mb} \text {, with } 12 \text { layers in PBL, } \\
\text { with the height of first model layer of } 27.3-43.9 \mathrm{~m}\end{array}$ & $\begin{array}{l}22 \text { layers from } 0 \text { to } 12 \mathrm{~km} \text {, with } 12 \text { layers in PBL, with } \\
\text { the height of first model layer of } 38.6 \mathrm{~m}\end{array}$ \\
\hline $\begin{array}{l}\text { Chemical initial and boundary condi- } \\
\text { tions (ICs and BCs) }\end{array}$ & $\begin{array}{l}\text { Global-through-urban WRF/Chem } \\
\text { (GU_WRF/Chem) of Zhang et al. (2012d) }\end{array}$ & $\begin{array}{l}\text { The output of the global chemistry transport model } \\
\text { Mozart } 2 \text { simulation over a typical year for gas, and } \\
\text { the outputs of the Goddard Chemistry Aerosol Radia- } \\
\text { tion and Transport (GOCART, Chin et al., 2000) for PM } \\
\text { species }\end{array}$ \\
\hline Anthropogenic emissions & 2001 EMEP (http://www.emep.int/) & Same as WRF/Chem-MADRID \\
\hline Dust emissions & Online module of modified Shaw (2008) & None \\
\hline $\begin{array}{l}\text { Sea-salt emissions } \\
\text { Biogenic }\end{array}$ & $\begin{array}{l}\text { Online module of Gong et al. (2002) } \\
\text { Offline emissions of Simpson et al. (1999) in the base- } \\
\text { line simulations; online emission modules, i.e., modi- } \\
\text { fied Guenther (Guenther et al.,1995) and MEGAN } 2.04 \\
\text { (Guenther et al., 2006) used in sensitivity simulations } \\
\text { over D01 }\end{array}$ & $\begin{array}{l}\text { Monahan et al. (1986) } \\
\text { Offline emissions of Simpson et al. (1999) }\end{array}$ \\
\hline Gas-phase chemistry & CB05 (Yarwood et al., 2005) & Same as WRF/Chem-MADRID \\
\hline Photolysis & Fast-J (Wild et al., 2000) & $\begin{array}{l}\text { Fast-J (Wild et al., 2000), calculated every hour depend- } \\
\text { ing on the simulated aerosol concentration }\end{array}$ \\
\hline Aqueous-phase chemistry & $\begin{array}{l}\text { Carnegie Mellon University (CMU) mechanism of Fa- } \\
\text { hey and Pandis (2001) }\end{array}$ & Same as WRF/Chem-MADRID \\
\hline Heterogeneous chemistry & None & $\begin{array}{l}\text { Heterogeneous reactions of } \mathrm{HO}_{2}, \mathrm{NO}_{3} \text { and } \mathrm{N}_{2} \mathrm{O}_{5} \text { based } \\
\text { on Jacob (2000) }\end{array}$ \\
\hline Aerosol module & $\begin{array}{l}\text { Model of Aerosol, Dynamics, Reaction, Ionization, and } \\
\text { Dissolution (MADRID) (Zhang et al., 2004, 2010a) }\end{array}$ & $\begin{array}{l}\text { SIREAM-SuperSorgam (Debry et al., 2007; Kim et al., } \\
\text { 2011) }\end{array}$ \\
\hline Dry deposition for gases & Surface resistance of Wesely (1989) & $\begin{array}{l}\text { Zhang et al. (2003) with surface resistance of We- } \\
\text { sely (1989) }\end{array}$ \\
\hline Dry deposition for aerosol & Venkatram and Pleim (1999) & Zhang et al. (2001) \\
\hline Wet deposition for gases & $\begin{array}{l}\text { In- and below-cloud scavenging parameterization of } \\
\text { Easter et al. (2004), with the effective Henry's law con- } \\
\text { stant of } \mathrm{SO}_{2}, \mathrm{NH}_{3}, \mathrm{HNO}_{3}, \mathrm{HNO}_{2} \text {, and } \mathrm{HCl}\end{array}$ & $\begin{array}{l}\text { Below-cloud scavenging parameterization of Sportisse } \\
\text { and Dubois (2002) with the effective Henry's law con- } \\
\text { stant of } \mathrm{SO}_{2}, \mathrm{NH}_{3}, \mathrm{HNO}_{3}, \mathrm{HNO}_{2} \text {, and } \mathrm{HCl}\end{array}$ \\
\hline Wet deposition for aerosol & $\begin{array}{l}\text { In- and below-cloud wet removal of particulates (Easter } \\
\text { et al., 2004) }\end{array}$ & $\begin{array}{l}\text { In-cloud scavenging parameterization of Roselle and } \\
\text { Binkowski (1999) }\end{array}$ \\
\hline Aerosol activation & $\begin{array}{l}\text { Abdul-Razzak and Ghan (A-R\&G) (Abdul-Razzak and } \\
\text { Ghan, 2002) }\end{array}$ & $\begin{array}{l}\text { Particles are activated if they exceed a critical diameter } \\
\text { of } 0.7 \mathrm{~m} \text { (Strader et al., 1998) }\end{array}$ \\
\hline Aerosol direct effect & $\begin{array}{l}\text { Goddard shortwave radiative transfer model of Chou et } \\
\text { al. (1998) }\end{array}$ & None \\
\hline Aerosol indirect effect & $\begin{array}{l}\text { Aerosol-cloud-radiation-precipitation interactions as } \\
\text { described in Chapman et al. (2009) }\end{array}$ & None \\
\hline
\end{tabular}

over D01, D02, and D03 at the three different grid resolutions for January and July 2001. These simulations are designed to evaluate the capability of WRF in capturing seasonal variations of major meteorological variables and the sensitivity of the model predictions to different horizontal grid resolutions. The simulations with both Polyphemus and WRF/Chem-MADRID are performed over D01 and D02 for July 2001 to study the sensitivity of chemical concentrations from both models to horizontal grid resolutions in summer when biogenic emissions and $\mathrm{O}_{3}$ concentrations are the highest throughout a year. The vertical resolution consists of 22 layers from the ground to $12 \mathrm{~km}$ altitude in all Polyphemus simulations and 23 layers from the ground to
$100 \mathrm{mb}(\sim 16 \mathrm{~km})$ in all WRF/Chem-MADRID simulations. The height of the first model layer is constant $(38.6 \mathrm{~m})$ in Polyphemus but varies between 27.3 and $43.9 \mathrm{~m}$ in WRF. The thickness of each layer is a constant in Polyphemus but varies in WRF. The Global Land Cover 2000 (GLC2000) map with 23 categories is used for land use coverage in Polyphemus, and the USGS 24-category land use data are used in WRF/Chem. Meteorological initial and boundary conditions (ICs and BCs, respectively) are based on the National Centers for Environmental Prediction Final Analysis (NCEP-FNL) reanalysis data.

As shown in Table 1, in WRF/Chem, the chemical ICs and BCs are based on the July 2001 simulation using the global- 


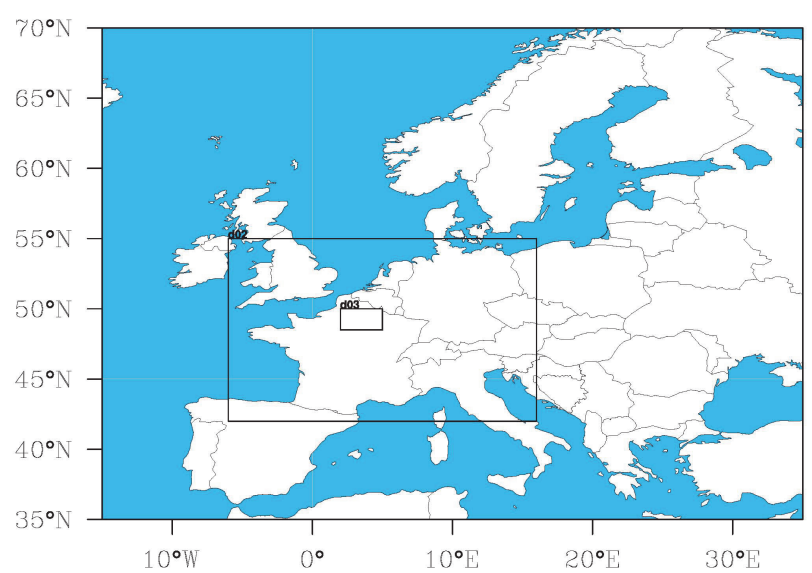

Fig. 1. Simulation domains: D01 over Western Europe, D02 over France, Germany, Netherlands, Belgium, Switzerland, Luxembourg, Slovenia, most of Austria, and parts of UK, Italy, Czech Republic, Spain, Croatia, and Poland, and D03 over the greater Paris region in France.

through-urban WRF/Chem (GU_WRF/Chem) of Zhang et al. (2012c). In Polyphemus, initial and boundary conditions are extracted from outputs of the global chemistry transport model Mozart 2 run over a typical year for gases, and outputs of the Goddard Chemistry Aerosol Radiation and Transport (GOCART, Chin et al., 2000) for the year 2001 for particulate sulfate, dust, black and organic carbon (Sartelet et al., 2007). Anthropogenic emissions are based on the 2001 EMEP expert inventory (http://www.emep.int) for both models. However, as indicated in Mallet and Sportisse (2006), large uncertainty exists in the vertical distribution of the EMEP emissions. In Polyphemus, the surface and elevated sources are assumed to be released in the first model layer and several upper layers, respectively, at the median height of each layer defined in WRF. They are distributed following a vertical profile in WRF/Chem. Given differences in the first model layer height and the thickness of each model layer between the two models, the vertical distributions of emissions are different, which will affect model predictions of chemical concentrations. Sea-salt emissions are simulated online based on Gong et al. (2002) in WRF/Chem-MADRID and offline based on Monahan et al. (1986) in Polyphemus. While Polyphemus does not simulate mineral dust emissions, WRF/Chem-MADRID uses a modified Shaw (2008) online module that generates emissions from soil surfaces (note that road dust emissions are not simulated) as described in Zhang et al. (2012c). The land types that can generate dust include grassland, shrubland, mixed shrubland/grassland, savanna, and barren or sparsely vegetated land. The biogenic emissions of Simpson et al. (1999) are used in the baseline simulations over D01 and D02 for both models. Sartelet et al. (2012) reported that the formations of $\mathrm{O}_{3}$ and SOA are sensitive to biogenic volatile organic compounds (BVOCs).

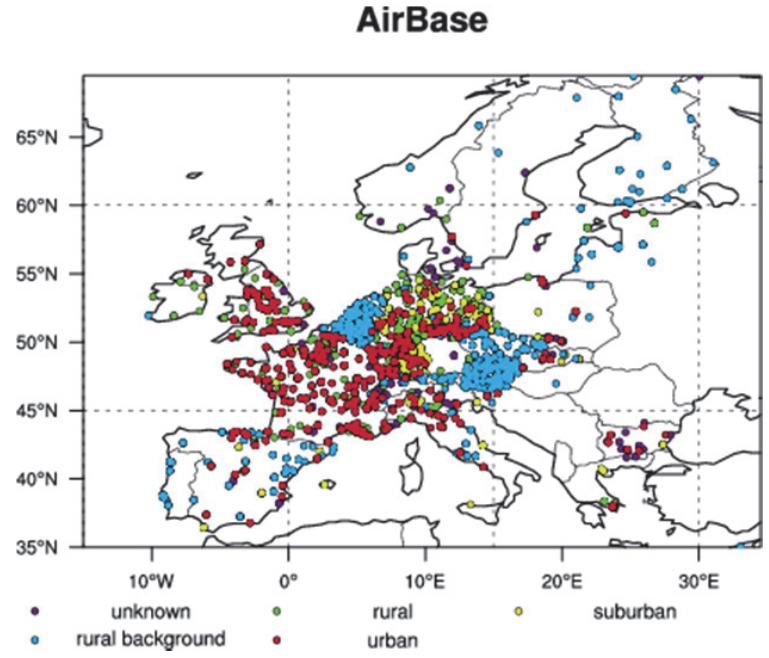

BDQA
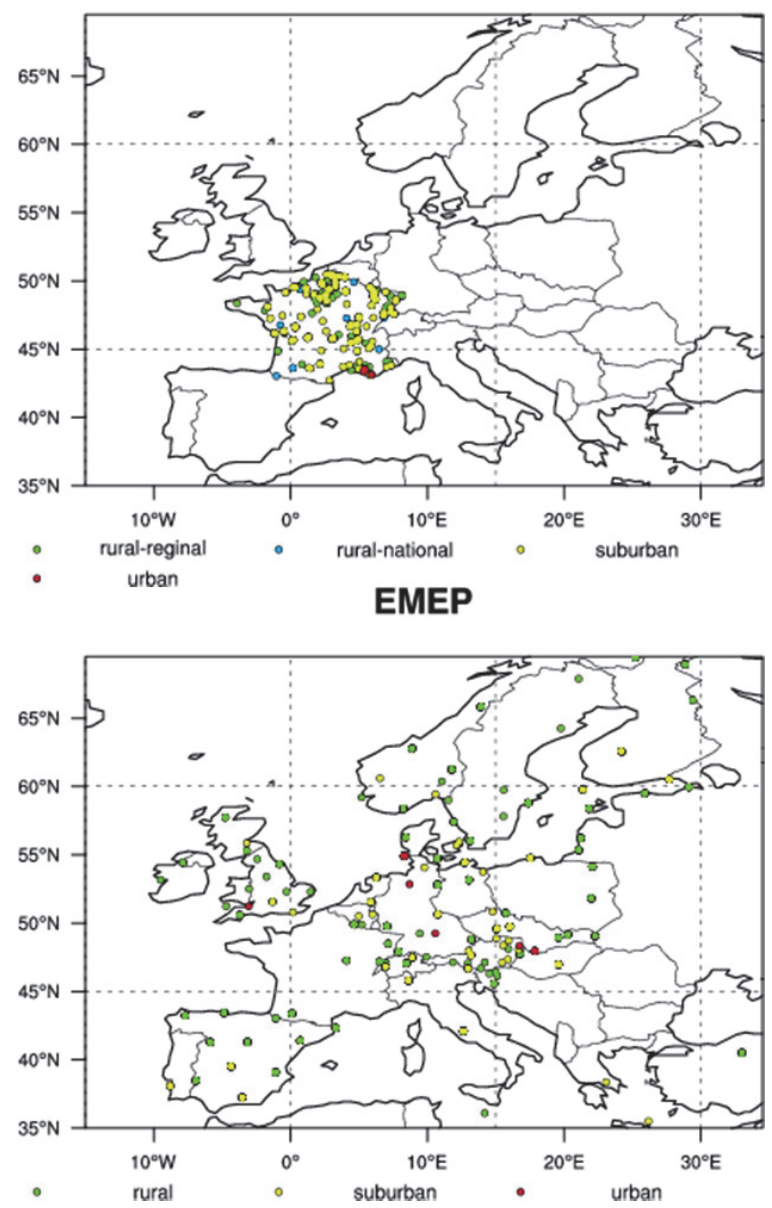

Fig. 2. Observational data from three networks: AirBase, BDQA, and EMEP used in model evaluation. 
To examine this sensitivity, two additional online biogenic emission inventories are used in the sensitivity simulations using WRF/Chem-MADRID: the Biogenic Emissions Inventory System Version 3.13 (BEIS3.13) based on Guenther et al. (1993, 1999) and updates in Schwede et al. (2005), which was further modified to map terpene emissions with terpenes treated in CB05 as described in Zhang et al. (2012c) and the Model of Emissions of Gases and Aerosols from Nature version 2.04 (MEGAN 2.04) of Guenther et al. (2006). BEIS3.13 and the Simpson emission scheme use leaf-scale emission factors, and MEGAN uses the canopy-scale emission factors (Pouliot and Pierce, 2009; Sartelet et al., 2012). MEGAN was developed to replace BEIS3, although the canopy-scale emission factors in MEGAN are still primarily based on leaf- and branch-scale emission measurements that are extrapolated to the canopy scale using a canopy environment model (Guenther et al., 2006). Although terpene emissions are distributed among pinene, limonene, and sesquiterpenes with constant factors in the Simpson and MEGAN schemes, different emission factors are used for several species in MEGAN (Sartelet et al., 2012). Differences among these emission schemes are discussed in several studies (e.g., Pouliot and Pierce, 2009; Steinbrecher et al., 2009; Sartelet et al., 2012).

To estimate the effects of aerosols on model predictions through various feedback mechanisms, an additional simulation is performed using the online-coupled WRF/ChemMADRID with the MEGAN2 BVOC module by turning off primary aerosol emissions and secondary aerosol formation. The differences in the model predictions between this simulation and the simulation using WRF/Chem-MADRID with the MEGAN2 BVOC module that include all primary aerosol emissions and secondary aerosol formation represent the effects of aerosols via various feedback mechanisms.

\section{Observational data and evaluation protocol}

Table 3 summarizes the surface and satellite datasets and variables used in the evaluation. The surface meteorological datasets include observations from the Baseline Surface Radiation Network (BSRN) and European Climate Assessment \& Dataset (ECA \& D), reanalysis data from NCEP, and a combination of observations and interpolated data from the National Oceanic and Atmospheric Administration Climate Diagnostics Center (NOAA/CDC). The meteorological variables evaluated include downward shortwave and longwave radiation fluxes (SWDOWN and LWDOWN, respectively), outgoing longwave radiation fluxes (OLR), temperature, specific humidity, and relative humidity at $2 \mathrm{~m}(\mathrm{~T} 2, \mathrm{Q} 2$, and RH2, respectively), wind speed at $10 \mathrm{~m}$ (WS10), wind direction at $10 \mathrm{~m}$ (WD10), and total daily precipitation (Precip). Simulated vertical profiles of temperature $(T)$, dew point (Td), as well as wind speed (WS) and wind direction (WD) are also evaluated using sounding observations from the
NCAR DS353.4 ADP. The chemical surface datasets include EMEP, the European air quality database (AirBase), and the Base de Données de la Qualité de l'Air (BDQA). Chemical variables evaluated include hourly and daily average $\mathrm{NH}_{3}, \mathrm{SO}_{2}, \mathrm{NO}_{2}$, daily average $\mathrm{HNO}_{3}$, hourly, maximum $1 \mathrm{~h}$ and maximum $8 \mathrm{~h}$ average $\mathrm{O}_{3}$, and hourly and daily average $\mathrm{PM}_{2.5}, \mathrm{PM}_{10}$, and $\mathrm{PM}_{10}$ composition (i.e., sulfate $\left(\mathrm{SO}_{4}^{2-}\right)$, nitrate $\left(\mathrm{NO}_{3}^{-}\right)$, ammonium $\left(\mathrm{NH}_{4}^{+}\right)$, sodium $\left(\mathrm{Na}^{+}\right)$, and chloride $\left.\left(\mathrm{Cl}^{-}\right)\right)$. EC and organic matter (OM) are not evaluated because of a lack of observations. EMEP contains data from the Convention on Long-Range Transboundary Air Pollution and represents hourly $\mathrm{O}_{3}$ data and daily data for other species at regional background sites mostly at farmland, rural, and lightly forested areas (Torseth and Hov, 2003). The AirBase database contains observations from the European Air Quality monitoring network (EuroAirnet) provided by European Union Member States, European Environment Agency member countries, and cooperating countries. It contains hourly data for all species and additional daily data for $\mathrm{PM}_{2.5}, \mathrm{PM}_{10}$, and $\mathrm{PM}_{10}$ composition at various types of sites such as rural background, rural, suburban, urban, traffic, and industrial sites. BDQA is the French database for air quality that covers France with hourly measurements at various types of sites. Because the grid resolution used in this work is not commensurate with urban, traffic and industrial sites, those sites from the AirBase and the BDQA are excluded from the model evaluation, except for urban background sites in AirBase. Large uncertainties exist in these observational data due to artifacts in the measurements and the impacts of local geographical conditions on the measurements (Schaap et al., 2004; Sartelet et al., 2007). The satellite datasets include the Total Ozone Mapping Spectrometer/the Solar Backscatter UltraViolet (TOMS/SBUV), the Measurements Of Pollution In The Troposphere (MOPITT), the Global Ozone Monitoring Experiment (GOME), and the Moderate Resolution Imaging Spectroradiometer (MODIS). The variables evaluated column concentrations of tropospheric $\mathrm{CO}$ and $\mathrm{NO}_{2}$, tropospheric $\mathrm{O}_{3}$ residual (TOR), and aerosol optical depth (AOD). To evaluate all observations related to MODIS, the monthly-mean AOD predictions are calculated as an average of column-integrated values during 15:00-20:00 UTC when the Terra satellite passes over Europe, following Roy et al. (2007).

The protocols for performance evaluation follow those used in Zhang et al. (2009, 2012a), including spatial distributions, temporal variation including daily values over the whole domain and hourly values at specific sites, and domainwide statistics. Statistics includes the mean bias (MB), mean gross error (MGE), the root mean squared error (RMSE), the normalized mean bias (NMB), the normalized mean error (NME), correlation coefficient (Corr), and index of agreement (IOA). The model performance is evaluated over the D01/D02/D03 domains for WRF simulations, over the D01/D02 domains for the WRF/Polyphemus 
Table 2. Domain, configurations, and physical options used in WRF.

\begin{tabular}{ll}
\hline Simulation period & Jan and Jul 2001 \\
\hline Domain & Western Europe (WE, D01) and a portion of WE (D02) \\
\hline Horizontal resolution & $\begin{array}{l}\left.0.5^{\circ} \text { over D01 }(100 \times 70), 0.125^{\circ} \text { over D02 (176 } \times 104\right), \text { and } \\
0.025^{\circ} \text { over D03 }(90 \times 50)\end{array}$ \\
\hline Vertical resolution* & 23 layers from 1000-100 mb, with 12 layers in PBL \\
\hline Meteorological IC & The National Centers for Environmental Prediction Final \\
and BC & Analysis (NCEP-FNL) reanalysis data \\
\hline Shortwave radiation & Goddard shortwave radiation scheme (Chou et al., 1998) \\
\hline Longwave radiation & $\begin{array}{l}\text { The rapid radiative transfer model (RRTM) (Mlawer et al., } \\
1997)\end{array}$ \\
\hline Land surface & Community National Centers for Environmental Prediction \\
& RCEP), Oregon State University, Air Force, and Hydrologic \\
& Desearch Lab-NWS Land Surface Model (NOAH) (Chen and \\
\hline Surface layer & Monin-Obukhov (Monin and Obukhov, 1954; Janjic, 2002) \\
\hline PBL & YonSei University Scheme (YSU) (Hong et al., 2006) \\
\hline Cumulus & Grell-Devenyi ensemble (Grell and Devenyi, 2002) \\
\hline Microphysics & Purdue Lin (Lin et al., 1983; Chen and Sun, 2002) \\
\hline 22 layers from the ground to 12 km are used in all Polyphemus simulations.
\end{tabular}

and WRF/Chem-MADRID simulations using offline BVOC emissions, and over the D01 domain for the sensitivity simulations using WRF/Chem-MADRID with two online BVOC emission modules. In addition to domainwide statistics, performance statistics is also calculated at individual sites. Since WD10 is a vector, a difference between $0^{\circ}$ and $360^{\circ}$ in the wind rose plot actually indicates a zero bias (rather than a difference of $360^{\circ}$ ); treating it as a numerical value in the traditional statistics calculation may give misleading results (Zhang et al., 2006). Therefore, for situations in which the differences between observed and simulated WD10 are greater than $180^{\circ}$, the simulated WD10 is adjusted to account for the actual differences between it and observed WD10 in the wind rose plot in the statistical calculations and plotting.

\section{Evaluation of meteorological predictions}

\subsection{Spatial distribution and domainwide performance statistics}

Table 4a shows domainwide performance statistics over D01 for the nine meteorological variables evaluated. Figures 3 and 4 show simulated spatial distributions of $\mathrm{T} 2, \mathrm{RH} 2$, WSP10, WD10, and Precip overlaid with observations over D01 and their associated MBs in January and July, respectively. In January, SWDOWN is largely overpredicted by the simulation at a horizontal grid resolution of $0.5^{\circ}$ with an NMB of $66.3 \%$, whereas LWDOWN is slightly underpredicted with an NMB of $-1.8 \%$. The overpredictions of SWDOWN are mainly attributed to the overestimation of the heating rates resulting from the underestimation of the cloud optical thickness (COT) by the Goddard shortwave radiation scheme, because the scheme in this version of WRF did not account for the contributions of snow, rain, and graupel to COT and thin cloud radiative forcing (Shi et al., 2007; Zhang et al., 2012a). Uncertainties may also exist in the observations as data are only available at six sites from BSRN. OLR is overpredicted with an NMB of $13.2 \%$, likely because the RRTM longwave radiation scheme coupled with the Goddard shortwave radiation scheme tends to overpredict radiation heating (Shi et al., 2007). WRF reproduces the observed spatial gradients with the coldest temperature in the northwest and the hottest in the south. The largest cold biases $(-5$ to $-2{ }^{\circ} \mathrm{C}$ ) occur in the Alps area, one of the great mountain range systems in Europe, which stretches about $1200 \mathrm{~km}$ across seven countries from Austria and Slovenia in the east, Switzerland, Liechtenstein, Germany, France to the west and Italy and Monaco to the south, indicating the model's difficulty in capturing the temperature variations in mountainous regions. The cold biases are also large $\left(-3\right.$ to $\left.-1{ }^{\circ} \mathrm{C}\right)$ in the eastern portion of the domain where the temperatures are low, likely due to too cold soil temperature, too much soil moisture, too many daytime clouds, and poor treatment of snow-related processes as reported in several mesoscale 


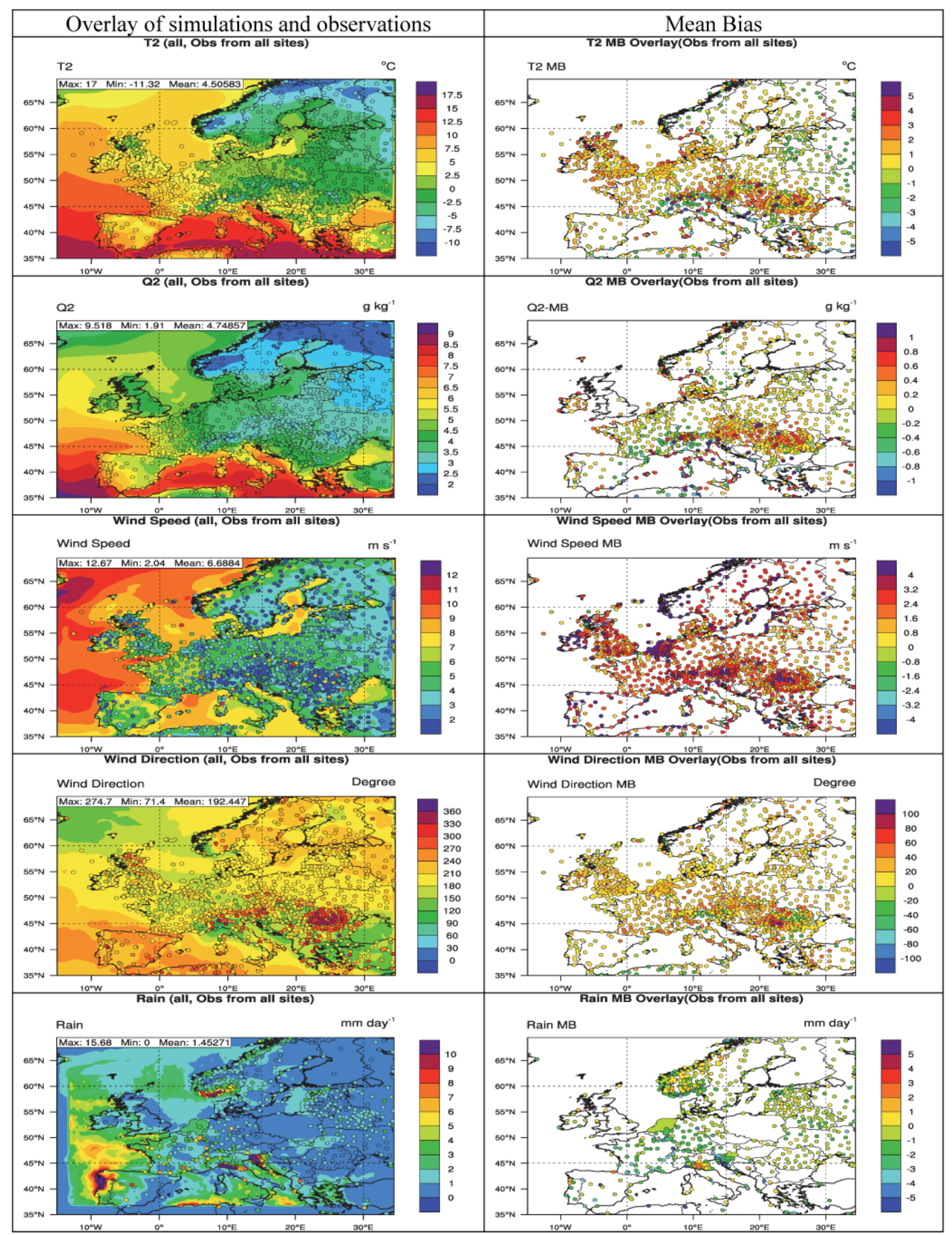

Fig. 3. Simulated T2, RH2, WSP10, WD10, and precipitation by WRF overlaid with observations in January 2001 (left column) and their associated mean biases (right column). Note that for WD10, 0 degree is equivalent to 360 degrees in the wind rose plot.

meteorology modeling studies using MM5 (e.g., Olerud and Sims, 2004; Zhang et al., 2011b) and WRF (Zhang et al., 2010b). Those cold biases are compensated by the warm biases over the rest of areas, particularly over the UK, Ireland, Denmark, the Netherlands, and eastern Austria, leading to a net domainwide $\mathrm{MB}$ of $0.5^{\circ} \mathrm{C}$ and an NMB of $19.2 \%$. The simulation also captures spatial variation of $\mathrm{Q} 2$, with the dri- est values in the northwest and the wettest in the south. The largest dry biases occur in the south where Q2 is high ( -1 to $-0.2 \mathrm{~g} \mathrm{~kg}^{-1}$ ) with a high density of large underpredictions in the Alps. The largest wet biases $\left(0.2-1 \mathrm{~g} \mathrm{~kg}^{-1}\right)$ occur over eastern Austria, Hungary, Romania and Ireland, which compensate the dry biases, leaving to a nearly perfect agreement with observations domainwide (with an $\mathrm{MB}$ of $0.1 \mathrm{~g} \mathrm{~kg}^{-1}$ 


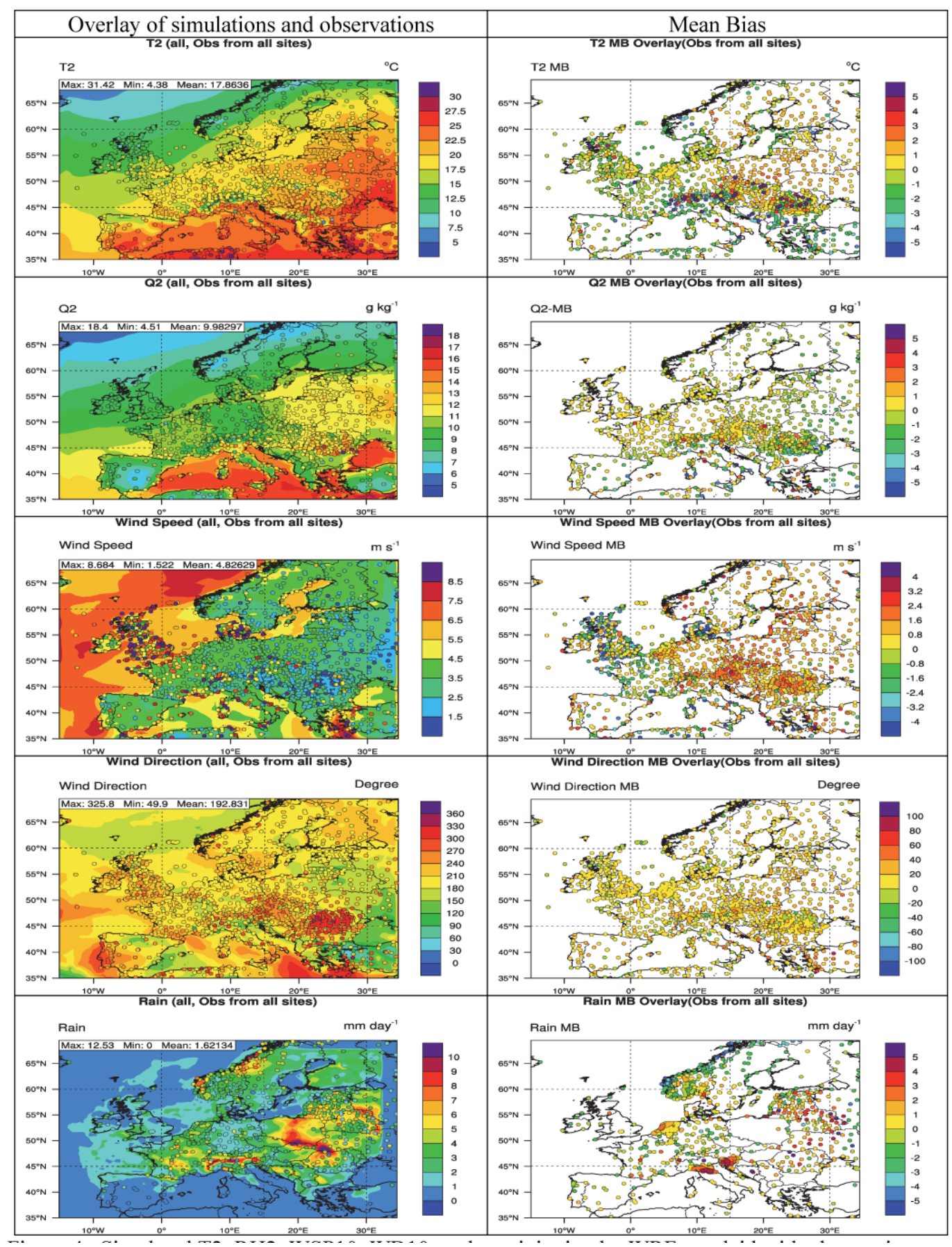

Fig. 4. Simulated T2, RH2, WSP10, WD10, and precipitation by WRF overlaid with observations in January 2001 (left column) and their associated mean biases (right column). Note that for WD10, 0 degree is equivalent to 360 degrees in the wind rose plot.

and an NMB of $3.0 \%)$. WS10 is grossly overpredicted at almost all sites (MB of $2.1 \mathrm{~m} \mathrm{~s}^{-1}$ and NMB of $59.2 \%$ ), with the worst performance (MBs $>1.6 \mathrm{~m} \mathrm{~s}^{-1}$ ) over several countries in low-lying coastal areas (e.g., Ireland, the Netherlands, Finland, Estonia, Lithuania, and the eastern coastal region of Sweden) and several countries in the Alps (e.g., Switzerland, Liechtenstein, Austria) and the Carpathian Mountains (e.g.,
Romania). These results indicate the model's difficulty in simulating wind patterns and mesoscale circulation systems such as sea breeze and bay breeze and their interactions with land over complex terrain. The high WS10 bias is mainly attributed to a poor representation of surface drag exerted by the unresolved topography such as hills and valleys and other smaller scale terrain features in WRF (Mass and Ovens, 
Table 3. Parameters and associated observational database included in the model evaluation.

\begin{tabular}{|c|c|c|c|}
\hline Database $^{1}$ & Parameter & $\begin{array}{l}\text { Data Frequency (number of sites) or } \\
\text { spatial/temporal resolutions for level } \\
3 \text { satellite data }\end{array}$ & Data Source \\
\hline BSRN & SWDOWN, LWDOWN & $\begin{array}{l}\text { Every minute ( } 6 \text { sites for SWDOWN, } \\
5 \text { sites for LWDOWN) }\end{array}$ & $\begin{array}{l}\text { http://www.bsrn.awi.de/en/data/ } \\
\text { data_retrieval_via_pangaea/ }\end{array}$ \\
\hline NOAA-CDC & OLR & $\begin{array}{l}\text { Monthly (global coverage), } 2.5^{\circ} \\
\times 2.5^{\circ}\end{array}$ & $\begin{array}{l}\text { http://www.cdc.noaa.gov/cdc/data. } \\
\text { interp_OLR.html; Liebmann and } \\
\text { Smith (1996) }\end{array}$ \\
\hline $\mathrm{NCEP}^{2}$ & T2, Q2, RH2, WS10, WD10 & Hourly (1677) & http://rda.ucar.edu/datasets/ds464.0/ \\
\hline ECA\&D & Precip & Daily (1999) & http://eca.knmi.nl, Klein et al. (2002) \\
\hline $\begin{array}{l}\text { NOAA/ESRL } \\
\text { Radiosonde Database }\end{array}$ & $\begin{array}{l}\text { Altitude, vertical profiles of pressure, } \\
\text { temperature, the dew point tempera- } \\
\text { ture, wind speed, wind direction }\end{array}$ & $\begin{array}{l}\text { Twice a day }(00: 00 \text { and } \\
\text { 12:00 GMT })(151 \text { sites })\end{array}$ & http://www.esrl.noaa.gov/raobs/ \\
\hline AirBase & $\begin{array}{l}\mathrm{O}_{3}, \mathrm{SO}_{2}, \mathrm{NO}_{2}, \mathrm{NH}_{3}, \mathrm{PM}_{2.5}, \mathrm{PM}_{10} \text {, } \\
\text { and } \mathrm{PM}_{10} \text { composition }\left(\mathrm{SO}_{4}^{2-}, \mathrm{NO}_{3}^{-} \text {, }\right. \\
\left.\mathrm{NH}_{4}^{+} \text {, and } \mathrm{Cl}^{-}\right)\end{array}$ & $\begin{array}{l}\text { Hourly }\left(1113 \text { for } \mathrm{O}_{3}, 975 \text { for } \mathrm{SO}_{2} \text {, }\right. \\
1093 \text { for } \mathrm{NO}_{2}, 12 \text { for } \mathrm{NH}_{3}, 4 \text { for } \\
\left.\mathrm{PM}_{2.5}, 309 \text { for } \mathrm{PM}_{10}\right) \text {; daily (20 for } \\
\mathrm{SO}_{4}^{2-}, 9 \text { for } \mathrm{NO}_{3}^{-}, 9 \text { for } \mathrm{NH}_{4}^{+} \text {, and } \\
\left.7 \text { for } \mathrm{Cl}^{-}\right) \text {; stations in both } \mathrm{EU} \text { and } \\
\text { non-EU countries }\end{array}$ & $\begin{array}{l}\text { http://acm.eionet.europa.eu/databases/ } \\
\text { airbase }\end{array}$ \\
\hline EMEP & $\begin{array}{l}\mathrm{O}_{3}, \mathrm{SO}_{2}, \mathrm{NO}_{2}, \mathrm{HNO}_{3}, \mathrm{NH}_{3}, \mathrm{PM}_{10} \text {, } \\
\mathrm{PM}_{2.5}, \mathrm{PM}_{10} \text {, and } \mathrm{PM}_{10} \text { composition } \\
\left(\mathrm{SO}_{4}^{2-}, \mathrm{NO}_{3}^{-}, \mathrm{NH}_{4}^{+}, \mathrm{Na}^{+} \text {, and } \mathrm{Cl}^{-}\right)\end{array}$ & $\begin{array}{l}\text { Hourly } \mathrm{O}_{3}-\mathrm{H}(122) \text {; daily }(75 \text { for } \\
\mathrm{SO}_{2}, 59 \text { for } \mathrm{NO}_{2}, 26 \text { for } \mathrm{HNO}_{3}, 28 \\
\text { for } \mathrm{NH}_{3}, 26 \text { for } \mathrm{PM}_{2.5}, 37 \text { for } \mathrm{PM}_{10} \text {, } \\
73 \text { for } \mathrm{SO}_{4}^{2-}, 46 \text { for } \mathrm{NO}_{3}^{-}, 48 \text { for } \\
\mathrm{NH}_{4}^{+}, 21 \text { for } \mathrm{Na}^{+}, 18 \text { for } \mathrm{Cl}^{-} \text {); sta- } \\
\text { tions separated in nearly } 30 \text { countries }\end{array}$ & http://www.emep.int/ \\
\hline BDQA & $\mathrm{O}_{3}, \mathrm{SO}_{2}, \mathrm{NO}_{2}, \mathrm{PM}_{2.5}, \mathrm{PM}_{10}$ & $\begin{array}{l}\text { Hourly }\left(138 \text { for } \mathrm{O}_{3}, 64 \text { for } \mathrm{SO}_{2}, 81\right. \\
\text { for } \mathrm{NO}_{2}, 21 \text { for } \mathrm{PM}_{2.5} \text {, and } 35 \text { for } \\
\left.\mathrm{PM}_{10}\right)\end{array}$ & http://www.buldair.org/ \\
\hline MOPITT & $\mathrm{CO}$ & $1^{\circ} \times 1^{\circ}$, every $0.4 \mathrm{~s}$, compiled as daily & http://www.acd.ucar.edu/mopitt/ \\
\hline GOME & $\begin{array}{l}\mathrm{NO}_{2} \\
\text { Tropospheric column ozone (TCO) }\end{array}$ & $0.5^{\circ} \times 0.5^{\circ}, 10: 30$ a.m. local time & $\begin{array}{l}\text { https://earth.esa.int/web/guest/missions/ } \\
\text { esa-operational-eo-missions/ers/ } \\
\text { instruments/gomel }\end{array}$ \\
\hline TOMS/SBUV & Tropospheric ozone residual (TOR) & $1.25^{\circ} \times 1^{\circ}, 3$ or 4 times per day & $\begin{array}{l}\text { http://asd-www.larc.nasa.gov/TOR/data. } \\
\text { html }\end{array}$ \\
\hline MODIS & Aerosol optical depth (AOD) & $1^{\circ} \times 1^{\circ}, 10: 30$ a.m. local time & http://modis.gsfc.nasa.gov/ \\
\hline
\end{tabular}

${ }^{1}$ AirBase: European air quality database, the information of number of sites based on 2003; BDQA: Base de Données de la Qualité de l'Air, a French database for air quality.

${ }^{2}$ NCEP contains pressure, height, T2, dew point, WS10, and WD10. Q2 and RH2 were calculated using T2, dew point, and pressure.

2010, 2011). Similar large positive biases in WS10 are found for the applications of WRF in both winter and summer in the US (Yahya et al., 2012) and East Asia (Zhang and Zhang, 2012). WD10 predictions agree reasonably well with observations. The MBs for WD10 at most sites in January are within $30^{\circ}$, with larger MBs occurring in complex terrains such as the Alps and the Carpathian Mountains. The domain average MB, NMB, and IOA are $14.4^{\circ}, 7.1 \%$, and 0.7 , respectively. Precip is underpredicted at many sites with an MB of $-1.7 \mathrm{~mm} \mathrm{day}^{-1}$ and an NMB of $-54.8 \%$, particularly in the Alps and coastal areas in Norway and Estonia where the precipitation levels vary greatly (e.g., $1-10 \mathrm{~mm} \mathrm{day}^{-1}$ over the Alps), making an accurate prediction at this grid resolution very challenging.

Similar to January, SWDOWN in July is largely overpredicted with an NMB of $69.3 \%$ over D01, and LW-
DOWN is slightly underpredicted with an NMB of $-3.8 \%$. In addition to possible underpredictions in COT associated with the above limitations in the Goddard shortwave radiation scheme, the overpredictions of SWDOWN in summer are partly attributed to the fact that the effect of cumulus clouds on radiation and the contribution of convective clouds to cloud water content are not accounted for in this version of WRF (Zhang et al., 2012a, b). The overpredictions in SWDOWN in this work are consistent with those reported by Zhang et al. (2012a) from the July 2001 application of WRF/Chem over continental US and the evaluation of SWDOWN against observations from the US networks (i.e., CASTNET and SEARCH) and those reported by Zhang et al. (2012b) from the January and July 2001 application of the global-through-urban WRF/Chem over global and nested domains, and the evaluation of SWDOWN against 


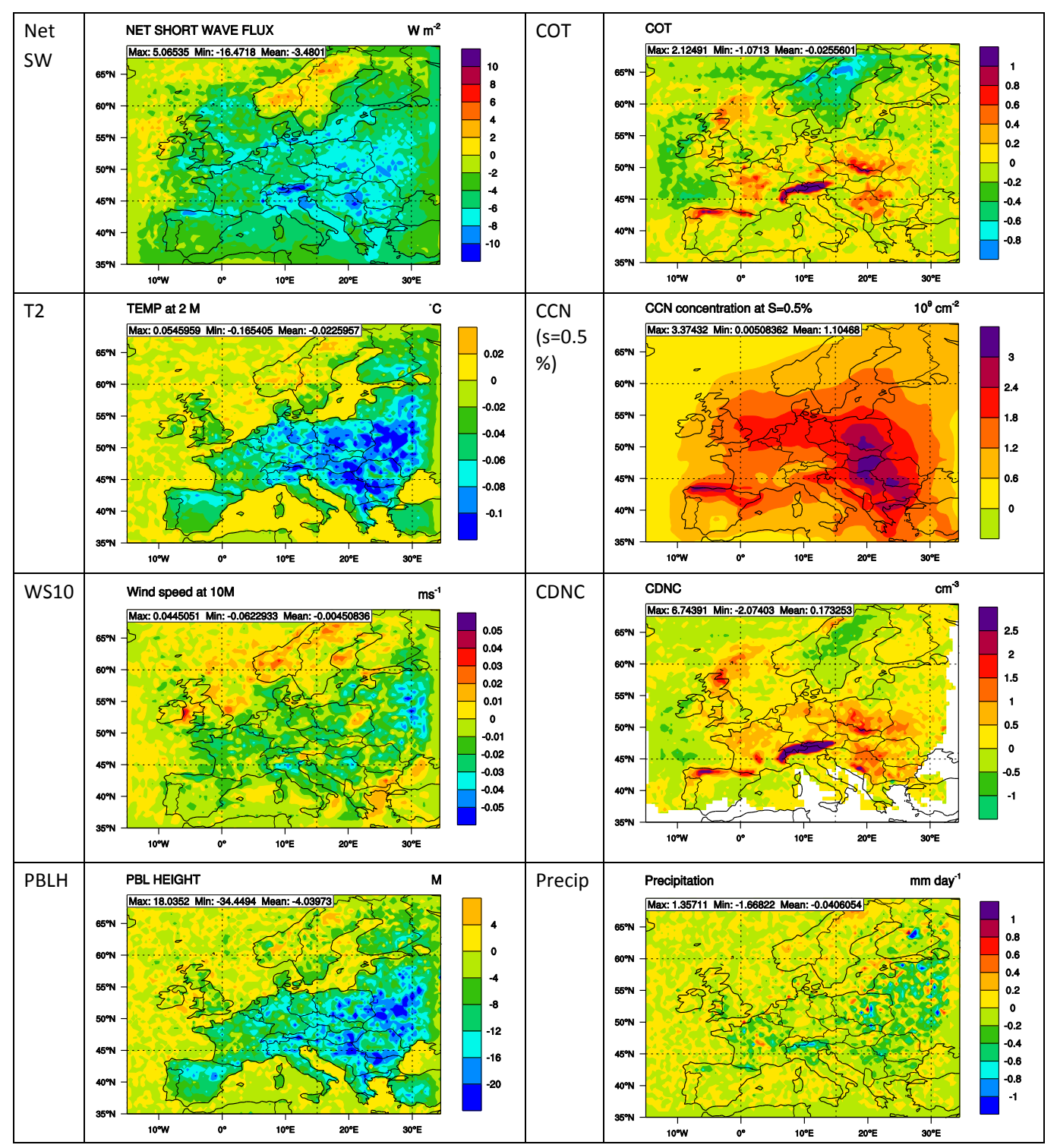

Fig. 5. Simulated changes in meteorological variables due to the direct, semi-direct, and indirect effects of aerosols by WRF/Chem-MADRID in July 2001 over D01.

observations from BSRN, CASTNET, and SEARCH. OLR performs slightly better in July than in January, with an NMB of $6.9 \%$. Similar to January, $0.5^{\circ}$ in July captures well the spatial gradients of T2 and Q2 with the coldest/driest values in the northwest portion of the domain and the hottest/wettest in the southeast. The largest cold biases in T2 occur in the southern Alps, the Balkan and Rhodope mountains in Bulgaria and the Pontic and Taurus mountains in Turkey, and the largest warm biases in T2 occur on the northern edge of the Alps, eastern Austria, and central Romania. These biases compensate each other, resulting in an overall good agreement with the observed $\mathrm{T} 2$ with an $\mathrm{MB}$ of $-0.3^{\circ} \mathrm{C}$ and an $\mathrm{NMB}$ of $-1.5 \%$. Inaccurate predictions of clouds and land surface heat fluxes may explain largely the biases in $\mathrm{T} 2$ predictions. The driest biases in Q2 occur in the south where Q2 is the highest, and the wettest biases occur over the northern edge of the Alps and Austria. The compensation of dry and wet biases results in a domainwide $\mathrm{MB}$ of $-0.1{ }^{\circ} \mathrm{C}$ and an NMB of $-1.2 \%$. Compared with the results in January, WS10 is overpredicted at most sites but to a lesser extent and even becomes underpredicted at many sites in the UK, Denmark, and France with MBs of -4 to $-0.8 \mathrm{~m} \mathrm{~s}^{-1}$; their compensation leads to a very good agreement with a domainwide MB $\left(-0.1 \mathrm{~m} \mathrm{~s}^{-1}\right)$ and NMB $(-2.3 \%)$. Simulated WD10 predictions in July agree better with observations than in January. The MBs for WD10 predictions at most sites in 


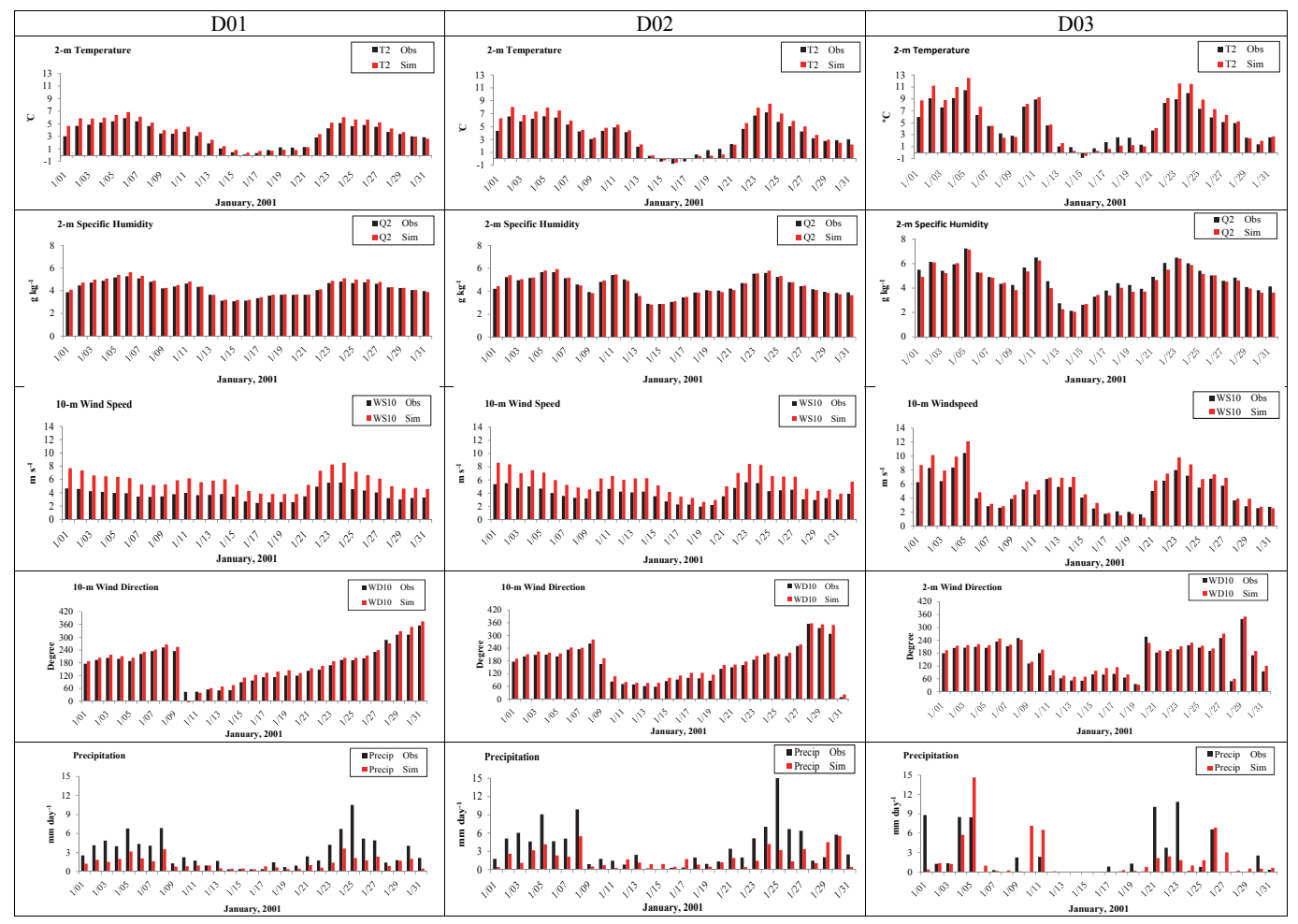

Fig. 6. Simulated and observed daily mean T2, QV2, WS10, WD10, and precipitation by WRF in January 2001 over D01 (left column), D02 (middle column), and D03 (right column).

July are also within $20^{\circ}$, and larger MBs only occur at a few monitoring sites. The domain average MB, NMB, and IOA are $9.2^{\circ}, 4.2 \%$, and 0.6 , respectively. Differently from January, Precip is moderately overpredicted at most sites, but largely underpredicted at some sites, mostly in several regions (e.g., Norway, Estonia, Latvia, and Belarus) in the northern portion of the domain. The compensation of overpredictions and underpredictions leads to a domainwide $\mathrm{MB}$ of $0.3 \mathrm{~mm} \mathrm{day}^{-1}$ and an NMB of $9.9 \%$. The underprediction in winter but overprediction in summer in Precip is consistent with other WRF and WRF/Chem applications (Yahya et al., 2012). The underprediction in winter is likely due to underpredictions in ice clouds that contribute to most precipitation in winter, resulting from a lack of ice nucleation treatment in WRF. As reported by Zhang et al. (2010b), the overprediction in summer is most likely due to too frequent afternoon convective rainfall and/or an overestimation in the intensity of the rainfall predicted by Grell-Devenyi ensemble cumulus parameterization, as well as a bug in the Purdue Lin cloud microphysics that causes the overprediction of cloud ice, graupel, as well as surface rainfall (http: //www.mmm.ucar.edu/wrf/users/wrfv3/known-prob.html) in WRF/Chem v3.0 and older.

Several studies developed mesoscale model evaluation benchmarks for T2, Q2, WS10, and WD10 (e.g., Emery et al., 2001; Tesche et al., 2002). The benchmarks recom- mended by Emery et al. (2001) are MGE $\leq 2 \mathrm{~K}$, MB within $\pm 0.5 \mathrm{~K}$, and IOA $\geq 0.7$ for $\mathrm{T} 2$; $\mathrm{MGE} \leq 2 \mathrm{~g} \mathrm{~kg}^{-1}, \mathrm{MB}$ within $\pm 1 \mathrm{~g} \mathrm{~kg}^{-1}$, and IOA $\geq 0.7$ for Q2; RMSE $\leq 2 \mathrm{~m} \mathrm{~s}^{-1}$ and IOA $\geq 0.6$ for WS10; and MGE $\leq 20^{\circ}$ for WD10. The benchmarks recommended by Tesche et al. (2002) are slightly different: MGE $\leq 2 \mathrm{~K}, \mathrm{MB}$ within $\pm 0.5 \mathrm{~K}$, and IOA $\geq 0.8$ for $\mathrm{T} 2$; MGE $\leq 2 \mathrm{~g} \mathrm{~kg}^{-1}$, MB within $\pm 1 \mathrm{~g} \mathrm{~kg}^{-1}$, and IOA $\geq 0.6$ for Q2; RMSE $\leq 2 \mathrm{~m} \mathrm{~s}^{-1}$, MB within $\pm 0.5 \mathrm{~m} \mathrm{~s}^{-1}$ and IOA $\geq 0.6$ for WS10; and MGE $\leq 30^{\circ}$ and $\mathrm{MB}$ within $\pm 10^{\circ}$ for WD10. WRF simulations give MGE of $2.1 \mathrm{~K}$ and IOA of 0.9 for both months, and MB of $0.5 \mathrm{~K}$ in January and $-0.3 \mathrm{~K}$ in July, indicating an overall good performance for T2. For simulated Q2, MGE is $0.5 \mathrm{~g} \mathrm{~kg}^{-1}$, MB is $0.1 \mathrm{~g} \mathrm{~kg}^{-1}$, and IOA is 0.9 in January, and MGE is $1.2 \mathrm{~g} \mathrm{~kg}^{-1}$, MB is $-0.1 \mathrm{~g} \mathrm{~kg}^{-1}$, and IOA is 0.8 in July, indicating a very good performance in both months. For simulated WS10, RMSE is $3.5 \mathrm{~m} \mathrm{~s}^{-1}$ in January and $3.3 \mathrm{~m} \mathrm{~s}^{-1}$ in July, MB is $2.1 \mathrm{~m} \mathrm{~s}^{-1}$ in January and $-0.1 \mathrm{~m} \mathrm{~s}^{-1}$ in July, and IOA is 0.7 in both months, indicating an overall good performance in July but poor performance in January. For simulated WD10, MGE is $45.3^{\circ}$ in January and $44.2^{\circ}$ in July, and MB is $14.4^{\circ}$ in January and $9.2^{\circ}$ in July, indicating a relatively poor performance in both months, despite of an IOA of 0.7 for both months.

The meteorological fields generated from online-coupled WRF/Chem-MADRID are somewhat different from those generated by WRF because of the feedbacks between 


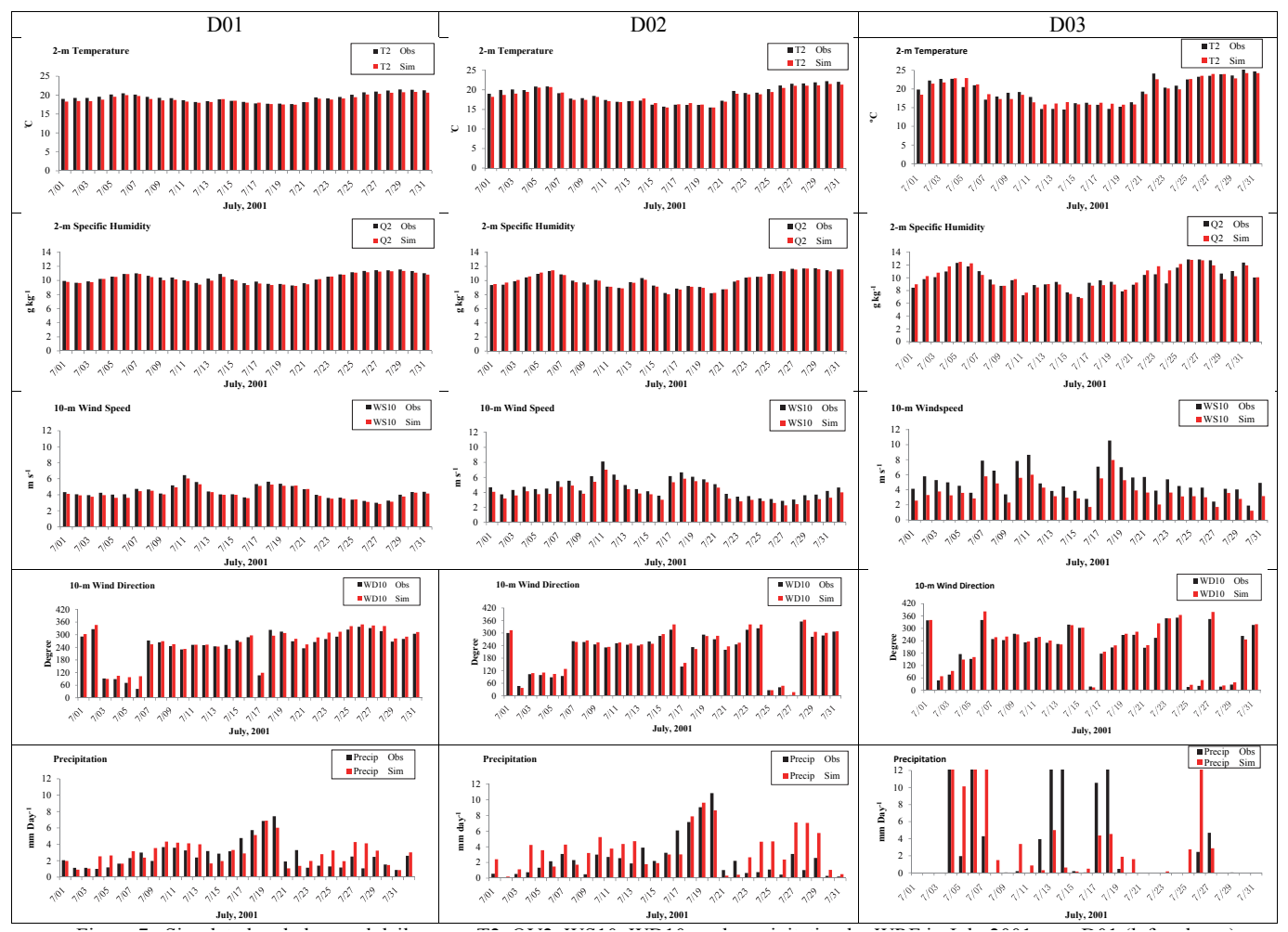

Fig. 7. Simulated and observed daily mean T2, QV2, WS10, WD10, and precipitation by WRF in July 2001 over D01 (left column), D02 (middle column), and D03 (right column).

meteorology and chemistry. For areas with high PM concentrations, aerosols tend to decrease SWDOWN and net shortwave radiation fluxes, near-surface temperature, latent heat fluxes, planetary boundary layer (PBL) height, and precipitation, but increase longwave radiation fluxes, COT, cloud liquid water content, cloud condensation nuclei $(\mathrm{CCN})$, cloud droplet number concentrations (CDNCs), and cloud fraction, which are consistent with the feedbacks to meteorology reported in WRF/Chem applications over the continental US and global-through-urban nested domains (Zhang et al., 2010b; 2012 b). Figure 5 shows simulated direct, semidirect, and indirect effects of aerosols on several meteorological variables. Aerosols lead to reduced net shortwave radiation fluxes, $2 \mathrm{~m}$ temperature, $10 \mathrm{~m}$ wind speed, PBL height, and precipitation in most areas, with domain-average values of $-3.5 \mathrm{~W} \mathrm{~m}^{-2},-0.02{ }^{\circ} \mathrm{C},-0.004 \mathrm{~m} \mathrm{~s}^{-1},-4.0 \mathrm{~m}$, and $-0.04 \mathrm{~mm} \mathrm{day}^{-1}$, respectively. It increases AOD (figure not shown) and CCN over the whole domain and COT and CDNC over most of the domain. Opposite changes in several variables (e.g., increased net shortwave radiation fluxes and wind speed but decreased COT and CDNC) are found in some areas such as Norway and Sweden where the level of PM concentrations are low. In these areas, the presence of PM causes higher latent heat flux from the earth's surface to the atmosphere, higher Q2 but lower CDNC, liquid water paths, and COT. Using a different CTM (i.e., CHIMERE) offline coupled with WRF, Péré et al. (2011) found that the direct radiative effect of aerosols can reduce both the PBL height by up to $30 \%$ and the horizontal wind speed by up to $6 \%$, which would enhance the PM pollution during the heat wave of summer 2003. Compared with the PM effects over East Asia and North America reported by several studies (e.g., Zhang et al., 2010b; Zhang and Zhang, 2012) using mesoscale WRF/Chem, those over Europe are consistent in sign but smaller in terms of magnitudes. However, due to limitation in the WRF/Chem model representations of aerosol feedbacks (e.g., the version of WRF/Chem used in this work does not include aerosol activated by convective clouds) (Zhang et al., 2012b), the estimates of aerosol feedbacks represent a low bound of the effect. While the domainwide performance statistics for major meteorological variables predicted by WRF/Chem-MADRID is overall similar to that of WRF, noticeable changes occur for several variables. For example, WRF/Chem-MADRID at a grid resolution of $0.125^{\circ} \mathrm{C}$ over D02 gives domainwide $\mathrm{T} 2$ of $18.5^{\circ} \mathrm{C}$ and Precip of $4.2 \mathrm{~mm} \mathrm{day}^{-1}$ in July 2001, which are lower than $19.0^{\circ} \mathrm{C}$ and $4.5 \mathrm{~mm} \mathrm{day}^{-1}$ as shown in Table $4 \mathrm{~b}$, changing NMBs from $-2.6 \%$ to $-5.6 \%$ for T2 (slight deterioration) and from $80.2 \%$ to $68.6 \%$ (moderate improvement) for Precip. These results indicate a need to further improve the model's representations of aerosol-meteorology interactions in online-coupled models. 
Table 4a. Comparison of performance statistics of WRF in January and July 2001 ${ }^{1,2}$.

\begin{tabular}{|c|c|c|c|c|c|c|c|c|c|c|c|}
\hline \multicolumn{12}{|c|}{ Simulations over D01 at a horizontal grid resolution of $0.5^{\circ}$ against observations over D01. } \\
\hline Variable $^{3}$ & Month & $\begin{array}{l}\text { Data } \\
\text { pair }\end{array}$ & $\begin{array}{l}\text { Mean } \\
\text { Obs }\end{array}$ & $\begin{array}{l}\text { Mean } \\
\text { Sim }\end{array}$ & Corr & MB & Gross Error & RMSE & $\begin{array}{l}\text { NMB } \\
\%\end{array}$ & $\begin{array}{l}\text { NME } \\
\%\end{array}$ & IOA \\
\hline \multirow{2}{*}{ SWDOWN } & January & 3834 & 35.2 & 58.5 & 0.7 & 23.3 & 36.4 & 81.0 & 66.3 & 103.5 & 0.8 \\
\hline & July & 4005 & 196.1 & 288.4 & 0.7 & 92.3 & 145.1 & 252.1 & 47.0 & 74.0 & 0.8 \\
\hline \multirow{2}{*}{ LWDOWN } & January & 3703 & 296.3 & 291.0 & 0.5 & -5.3 & 33.9 & 44.0 & -1.8 & 11.4 & 0.7 \\
\hline & July & 3532 & 335.9 & 353.9 & 0.3 & 18.0 & 35.4 & 48.8 & 5.4 & 10.5 & 0.6 \\
\hline \multirow{2}{*}{ OLR } & January & 5400 & 203.2 & 229.9 & 0.8 & 26.7 & 26.7 & 27.7 & 13.2 & 13.2 & 0.5 \\
\hline & July & 5400 & 244.9 & 261.7 & 1.0 & 16.8 & 16.9 & 17.7 & 6.9 & 6.9 & 0.8 \\
\hline \multirow{2}{*}{$\mathrm{T} 2$} & January & 781756 & 2.7 & 3.3 & 0.9 & 0.5 & 2.1 & 2.9 & 19.2 & 76.6 & 0.9 \\
\hline & July & 776307 & 19.3 & 19.0 & 0.9 & -0.3 & 2.1 & 2.9 & -1.5 & 10.8 & 0.9 \\
\hline \multirow{2}{*}{ Q2 } & January & 357535 & 4.1 & 4.2 & 0.9 & 0.1 & 0.5 & 0.7 & 3.0 & 12.4 & 0.9 \\
\hline & July & 385772 & 10.3 & 10.2 & 0.6 & -0.1 & 1.2 & 2.1 & -1.2 & 11.7 & 0.8 \\
\hline \multirow{2}{*}{ RH2 } & January & 781756 & 85.6 & 84.1 & 0.5 & -1.4 & 9.4 & 12.8 & -1.7 & 11.0 & 0.7 \\
\hline & July & 776307 & 73.3 & 73 & 0.7 & -0.2 & 10.4 & 13.8 & -0.3 & 14.2 & 0.8 \\
\hline \multirow{2}{*}{ WS10 } & January & 792740 & 3.5 & 5.6 & 0.6 & 2.1 & 2.7 & 3.5 & 59.2 & 75.7 & 0.7 \\
\hline & July & 787870 & 4.2 & 4.1 & 0.5 & -0.1 & 2.2 & 3.3 & -2.3 & 51.3 & 0.7 \\
\hline \multirow{2}{*}{ WD10 } & January & 783862 & 200.9 & 215.3 & 0.8 & 14.4 & 45.3 & 64.1 & 7.1 & 22.6 & 0.7 \\
\hline & July & 776755 & 220.3 & 229.5 & 0.9 & 9.2 & 44.2 & 62.5 & 4.2 & 20.1 & 0.6 \\
\hline \multirow{2}{*}{ Precip } & January & 43015 & 3.1 & 1.3 & 0.5 & -1.7 & 2.6 & 7.2 & -54.8 & 86.0 & 0.5 \\
\hline & July & 43020 & 2.6 & 2.9 & 0.4 & 0.3 & 3.3 & 6.9 & 9.9 & 125.1 & 0.6 \\
\hline
\end{tabular}

Table 4b. Comparison of performance statistics of WRF in January and July 2001 1,2.

\begin{tabular}{|c|c|c|c|c|c|c|c|c|c|c|c|c|c|c|c|c|c|c|c|}
\hline \multirow[t]{2}{*}{ Variable } & \multirow[t]{2}{*}{ Month } & \multirow[t]{2}{*}{ Data pair } & \multirow[t]{2}{*}{ Mean Obs } & \multicolumn{2}{|c|}{ Mean Sim } & \multicolumn{2}{|c|}{ Corr } & \multicolumn{2}{|c|}{ MB } & \multicolumn{2}{|c|}{ Gross Error } & \multicolumn{2}{|c|}{ RMSE } & \multicolumn{2}{|c|}{ NMB, $\%$} & \multicolumn{2}{|c|}{ NME, $\%$} & \multicolumn{2}{|c|}{ IOA } \\
\hline & & & & D01 & D02 & D01 & D02 & D01 & D02 & D01 & D02 & D01 & D02 & D01 & D02 & D01 & D02 & D01 & D02 \\
\hline \multirow[b]{2}{*}{ SWDOWN } & Jan & 2513 & 46.6 & 79.0 & 84.5 & 0.7 & 0.8 & 32.3 & 37.8 & 48.8 & 50.2 & 97.2 & 98.4 & 69.3 & 81.2 & 104.8 & 107.7 & 0.8 & 0.8 \\
\hline & Jul & 2715 & 185.7 & 304.6 & 334.9 & 0.6 & 0.7 & 118.9 & 149.2 & 171.6 & 178.1 & 288.2 & 297.7 & 64.0 & 80.4 & 92.4 & 95.9 & 0.7 & 0.8 \\
\hline \multirow{2}{*}{ LWDOWN } & Jan & 2960 & 295.2 & 283.9 & 276.0 & 0.5 & 0.6 & -11.3 & -19.1 & 35.4 & 33.0 & 44.9 & 42.5 & -3.8 & -6.5 & 12.0 & 11.1 & 0.7 & 0.7 \\
\hline & Jul & 2957 & 335.1 & 354.5 & 353.5 & 0.3 & 0.2 & 19.4 & 18.4 & 37.8 & 36.5 & 51.4 & 52.1 & 5.8 & 5.5 & 11.3 & 10.9 & 0.5 & 0.5 \\
\hline \multirow{2}{*}{$\mathrm{OLR}^{4}$} & Jan & $560 / 15604$ & $196.9 / 199.5$ & 231.1 & 233.5 & 0.7 & 0.7 & 34.2 & 34.0 & 34.2 & 34.0 & 34.6 & 34.5 & 17.4 & 17.0 & 17.4 & 17.0 & 0.2 & 0.3 \\
\hline & Jul & $560 / 15604$ & $243.1 / 244.2$ & 261.0 & 262.8 & 0.5 & 0.7 & 17.9 & 18.5 & 18.2 & 19.0 & 19.4 & 20.1 & 7.3 & 7.6 & 7.5 & 7.8 & 0.4 & 0.5 \\
\hline \multirow{2}{*}{$\mathrm{T} 2$} & Jan & 172005 & 3.7 & 3.7 & 3.8 & 0.8 & 0.9 & 0.0 & 0.1 & 2.6 & 2.4 & 3.5 & 3.2 & 0.0 & 3.2 & 71.3 & 64.9 & 0.9 & 0.9 \\
\hline & Jul & 168743 & 19.5 & 18.5 & 19.0 & 0.8 & 0.9 & -1.0 & -0.5 & 2.6 & 2.3 & 3.6 & 3.2 & -5.0 & -2.6 & 13.5 & 11.9 & 0.9 & 0.9 \\
\hline \multirow{2}{*}{ Q2 } & Jan & 121195 & 4.4 & 4.5 & 4.4 & 0.9 & 0.9 & 0.0 & -0.0 & 0.6 & 0.6 & 0.8 & 0.7 & 0.8 & -0.3 & 13.1 & 12.7 & 0.9 & 1.0 \\
\hline & Jul & 117020 & 10.1 & 10.1 & 10.1 & 0.7 & 0.7 & 0.0 & 0.0 & 1.3 & 1.2 & 1.7 & 1.6 & 0.2 & -0.05 & 12.4 & 12.2 & 0.8 & 0.9 \\
\hline \multirow[b]{2}{*}{ RH2 } & Jan & 172005 & 83.1 & 81.9 & 81.0 & 0.4 & 0.4 & -1.2 & -2.1 & 12.1 & 11.8 & 16.3 & 15.8 & -1.4 & -2.6 & 14.5 & 14.2 & 0.6 & 0.7 \\
\hline & Jul & 168734 & 71.3 & 73.5 & 71.7 & 0.7 & 0.7 & 2.1 & 0.4 & 11.0 & 10.8 & 14.2 & 13.1 & 3.0 & 0.5 & 15.4 & 15.2 & 0.8 & 0.8 \\
\hline \multirow{2}{*}{ WS 10} & Jan & 171539 & 3.3 & 5.5 & 5.1 & 0.6 & 0.6 & 2.1 & 1.8 & 2.8 & 2.5 & 3.6 & 3.3 & 63.1 & 52.5 & 83.9 & 74.7 & 0.7 & 0.7 \\
\hline & Jul & 168293 & 4.1 & 3.7 & 3.5 & 0.5 & 0.5 & -0.4 & -0.5 & 2.3 & 2.3 & 3.4 & 3.3 & -10.0 & -13.3 & 57.1 & 54.9 & 0.6 & 0.6 \\
\hline \multirow[b]{2}{*}{ WD10 } & Jan & 167707 & 197.5 & 210.4 & 208.8 & 0.8 & 0.8 & 12.9 & 11.3 & 57.0 & 53.7 & 75.8 & 72.8 & 6.5 & 5.7 & 28.9 & 27.1 & 0.6 & 0.6 \\
\hline & Jul & 164357 & 211.2 & 218.6 & 217.3 & 0.8 & 0.8 & 7.3 & 6.0 & 53.9 & 50.9 & 72.2 & 69.3 & 3.5 & 2.9 & 25.5 & 24.0 & 0.6 & 0.6 \\
\hline \multirow[b]{2}{*}{ Precip } & Jan & 13310 & 5.2 & 1.7 & 2.6 & 0.4 & 0.4 & -3.4 & -2.6 & 4.8 & 5.0 & 11.7 & 11.6 & -66.3 & -50.0 & 92.1 & 96.1 & 0.4 & 0.5 \\
\hline & Jul & 13340 & 2.5 & 3.7 & 4.5 & 0.4 & 0.3 & 1.3 & 2.0 & 4.0 & 4.8 & 8.2 & 9.7 & 52.5 & 82.3 & 163.9 & 196.0 & 0.6 & 0.5 \\
\hline
\end{tabular}

\subsection{Domainwide daily variation trends and sensitivity to horizontal grid resolution}

Domainwide mean daily meteorological predictions of $\mathrm{T} 2$, Q2, WS10, WD10, and Precip and observations from NCEP and ECA\&D over D01, D02, and D03 for both months are shown in Figs. 6 and 7. The performance statistics over D01, D02, and D03 at a horizontal grid resolution of $0.5^{\circ}, 0.125^{\circ}$, and $0.025^{\circ}$, respectively, are given in Tables $4 \mathrm{a}, \mathrm{b}$, and c, respectively. For a fair evaluation of the sensitivity of the model predictions to different grid resolutions, the perfor- mance statistics is also calculated over D02 using model predictions from D01 at a horizontal grid resolution of $0.5^{\circ}$ (see Table $4 \mathrm{~b}$ ) and over D03 using model predictions from D01 and D02 at horizontal grid resolutions of $0.5^{\circ}$ and $0.125^{\circ}$, respectively (see Table 4c).

In January, the simulated daily-mean T2 and Q2 agree reasonably well with observations at the three grid resolutions. Compared to the simulations at a horizontal grid resolution of $0.5^{\circ}$ over D02, the domainwide statistical performance at $0.125^{\circ}$ is slightly improved for Q2 but is slightly worse for $\mathrm{T} 2$ and $\mathrm{RH} 2$. Compared to the simulations at $0.5^{\circ}$ and 
Table 4c. Comparison of performance statistics of WRF in January and July 2001 1,2.

\begin{tabular}{|c|c|c|c|c|c|c|c|c|c|c|c|c|c|c|c|c|c|c|c|c|c|c|c|c|c|c|c|}
\hline \multicolumn{28}{|c|}{ Simulations over D01 and D02 at horizontal grid resolutions of $0.5^{\circ}$ and $0.125^{\circ}$, respectively, against observations over D02. } \\
\hline \multirow[t]{2}{*}{ Variable } & & \multirow{2}{*}{$\begin{array}{l}\text { Data } \\
\text { pair }\end{array}$} & \multirow{2}{*}{$\begin{array}{l}\text { Mean } \\
\text { Obs }\end{array}$} & \multicolumn{3}{|c|}{ Mean Sim } & \multicolumn{3}{|c|}{ Corr } & \multicolumn{3}{|c|}{ MB } & \multicolumn{3}{|c|}{ Gross Error } & \multicolumn{3}{|c|}{ RMSE } & \multicolumn{3}{|c|}{ NMB, $\%$} & \multicolumn{3}{|c|}{ NME, $\%$} & \multicolumn{3}{|c|}{ IOA } \\
\hline & & & & D01 & D02 & D03 & | D01 & D02 & D03 & | D01 & D02 & D03 & | D01 & $\mathrm{D} 02$ & D03 & | D01 & D02 & D03 & D01 & D02 & D03 & | D01 & D02 & D03 & | D01 & D02 & $\mathrm{D} 03$ \\
\hline \multirow[t]{2}{*}{$\mathrm{T} 2$} & Jan & 5736 & 4.8 & 5.6 & 5.6 & 5.5 & 0.9 & 0.9 & 0.9 & \begin{tabular}{|l|}
0.7 \\
\end{tabular} & 0.8 & 0.6 & $\begin{array}{ll}1.54 \\
\end{array}$ & 1.5 & 1.4 & \begin{tabular}{|l|l}
1.9 \\
\end{tabular} & 1.8 & 1.7 & \begin{tabular}{|l|l|} 
& 15.0
\end{tabular} & 15.8 & 13.2 & \begin{tabular}{|l|l|}
31.8 \\
\end{tabular} & 31.7 & 29.6 & \begin{tabular}{|l|l|}
0.9 \\
\end{tabular} & 1.0 & 1.0 \\
\hline & Jul & 5682 & 19.4 & 19.0 & 19.7 & 19.2 & \begin{tabular}{|l|}
0.9 \\
\end{tabular} & 0.9 & 0.9 & \begin{tabular}{|l|l|} 
& -0.4
\end{tabular} & 0.3 & -0.2 & \begin{tabular}{|l|l} 
& 1.52
\end{tabular} & 1.5 & 1.4 & \begin{tabular}{|l|}
1.9 \\
|
\end{tabular} & 1.9 & 1.8 & -2.1 & 1.6 & -0.8 & \begin{tabular}{|l|l} 
& 7.8
\end{tabular} & 7.7 & 7.3 & 1.0 & 1.0 & 1.0 \\
\hline Q2 & $\begin{array}{l}\text { Jan } \\
\text { Jul }\end{array}$ & $\begin{array}{l}4323 \\
4200\end{array}$ & $\begin{array}{l}4.8 \\
10.0\end{array}$ & \begin{tabular}{|l|}
4.8 \\
10.5
\end{tabular} & $\begin{array}{l}4.6 \\
10.1\end{array}$ & $\begin{array}{l}4.7 \\
10.2\end{array}$ & \begin{tabular}{|l|}
0.9 \\
0.8
\end{tabular} & $\begin{array}{l}0.9 \\
0.8\end{array}$ & $\begin{array}{l}1.0 \\
0.8\end{array}$ & \begin{tabular}{|l|}
-0.1 \\
0.5
\end{tabular} & $\begin{array}{l}-0.2 \\
0.1\end{array}$ & $\begin{array}{l}-0.2 \\
0.2\end{array}$ & \begin{tabular}{|l|}
0.34 \\
0.9
\end{tabular} & $\begin{array}{l}0.4 \\
0.9\end{array}$ & $\begin{array}{l}0.3 \\
0.9\end{array}$ & \begin{tabular}{|l|}
0.4 \\
1.2
\end{tabular} & $\begin{array}{l}0.5 \\
1.1\end{array}$ & $\begin{array}{l}0.4 \\
1.1\end{array}$ & \begin{tabular}{|l|}
-1.6 \\
5.0
\end{tabular} & $\begin{array}{l}-4.6 \\
1.4\end{array}$ & $\begin{array}{l}-3.8 \\
2.1\end{array}$ & \begin{tabular}{|l|}
7.0 \\
9.1
\end{tabular} & $\begin{array}{l}7.7 \\
8.7\end{array}$ & $\begin{array}{l}7.1 \\
8.6\end{array}$ & \begin{tabular}{|l|}
1.0 \\
0.9
\end{tabular} & $\begin{array}{l}1.0 \\
0.9\end{array}$ & $\begin{array}{l}1.0 \\
0.9\end{array}$ \\
\hline \multirow[t]{2}{*}{ RH2 } & Jan & 5 & 86 & 80.7 & 78 & 79 & \begin{tabular}{|l|l|}
0.7 \\
\end{tabular} & 0. & 0.7 & \begin{tabular}{|l|l} 
& -5.9
\end{tabular} & -8.4 & -6.9 & \begin{tabular}{|l|l} 
& 8.7
\end{tabular} & 10.4 & 9.3 & \begin{tabular}{|l|l}
10.8 \\
\end{tabular} & 21 & 11.7 & -6.8 & -9.6 & -8.0 & \begin{tabular}{l|l}
10.0 \\
\end{tabular} & 12.0 & 10.8 & \begin{tabular}{|l|l|} 
& 0.8
\end{tabular} & 0.7 & 0.8 \\
\hline & Jul & 5682 & 71.8 & 71.8 & 70.4 & 72.7 & 0.8 & 0.8 & 0.8 & \begin{tabular}{|l|l} 
&
\end{tabular} & -1.4 & 1.0 & \begin{tabular}{|l|}
8.1 \\
\end{tabular} & 9.3 & 8.8 & \begin{tabular}{|l|l}
11.5 \\
\end{tabular} & 11.7 & 10.9 & \begin{tabular}{|l|} 
\\
\end{tabular} & -2.0 & 1.3 & \begin{tabular}{|l}
12.9 \\
\end{tabular} & 12.9 & 12.3 & \begin{tabular}{|l|l}
.0 .0 \\
0.9
\end{tabular} & 0.9 & 0.9 \\
\hline \multirow[t]{2}{*}{ wS10 } & Jan & 5719 & 5.1 & 6.7 & 5.6 & 6.0 & \begin{tabular}{|l|}
0.9 \\
\end{tabular} & 0.4 & 0.9 & 1.5 & 0.5 & 0.9 & \begin{tabular}{|l|l}
1.8 \\
\end{tabular} & 1.3 & 1.4 & 2.3 & 1.8 & 1.9 & \begin{tabular}{|l|l}
29.7 \\
\end{tabular} & 9.9 & 16.6 & \begin{tabular}{|l|l}
34.9 \\
\end{tabular} & 25.6 & 27.8 & \begin{tabular}{|l|} 
\\
\end{tabular} & 0.9 & 0.9 \\
\hline & Jul & 5679 & 5.0 & 5.0 & 3.5 & 3.7 & \begin{tabular}{|l|l|} 
& 0.6
\end{tabular} & 0.6 & 0.6 & $\mid-1.2$ & -1.5 & -1.3 & \begin{tabular}{|l|l|} 
& 2.0
\end{tabular} & 2.2 & 2.1 & \begin{tabular}{|l|} 
\\
$\mid$
\end{tabular} & 3.1 & 3.0 & $\mid-24.0$ & -30.8 & -25.5 & \begin{tabular}{|l|l|} 
& 40.7
\end{tabular} & 43.4 & 41.8 & \begin{tabular}{|l|l|} 
& 0.7
\end{tabular} & 0.7 & 0.7 \\
\hline \multirow[t]{2}{*}{ WD10 } & Jan & 5716 & 166.5 & 183.8 & 181.5 & 180.5 & $\mid 0.9$ & 0.9 & 0.9 & \begin{tabular}{|l|l|} 
& 17.4
\end{tabular} & 15.0 & 14.0 & $\mid 25.0$ & 23.9 & 25. & \begin{tabular}{|l}
34.8 \\
\end{tabular} & 33.6 & 36.0 & \begin{tabular}{|l|l}
10.4 \\
\end{tabular} & 9.0 & 8.4 & \begin{tabular}{|l|l}
$\mid 15.0$ \\
\end{tabular} & 14.3 & 15.0 & 0.8 & 0.8 & 0.8 \\
\hline & Jul & 5668 & 199.2 & 207.0 & 207.8 & 20 & 0. & 0.9 & 0.9 & \begin{tabular}{|l|l|} 
&
\end{tabular} .8 & 8.6 & 9.4 & \begin{tabular}{|l|l} 
& 35.1
\end{tabular} & 35.1 & 35.9 & \begin{tabular}{|l|l} 
& 53.2
\end{tabular} & 52.8 & 54.1 & \begin{tabular}{|l|}
3.9 \\
\end{tabular} & 4.3 & 4.7 & \begin{tabular}{|l|l}
17.6 \\
\end{tabular} & 17.6 & 18.0 & \begin{tabular}{|l|l|} 
& 0.7
\end{tabular} & 0.7 & 0.7 \\
\hline \multirow[t]{2}{*}{ Precip } & Jan & 124 & 2. & 1.1 & 1. & 2.0 & \begin{tabular}{|l|}
0.6 \\
\end{tabular} & 0.5 & 0.4 & -1 & & - & \begin{tabular}{|l|l}
1.8 \\
\end{tabular} & 1.9 & 2.2 & 3 & & 3 & -4 & -4 & & 15 & & , & \begin{tabular}{|l|l|} 
& 0.7
\end{tabular} & 0.6 & 0.6 \\
\hline & Jul & 124 & 5.6 & 3.0 & 2.9 & 3.7 & \begin{tabular}{|l|}
0.7 \\
\end{tabular} & 0.7 & 0.5 & -2.6 & -2.7 & -1.9 & \begin{tabular}{|l|}
5.1 \\
\end{tabular} & 5.1 & 5.2 & 12.5 & 12.0 & 12.7 & -47.0 & -47.4 & -33.7 & \begin{tabular}{|l|l} 
& 91.1
\end{tabular} & 91.2 & 93.2 & 0.6 & 0.6 & 0.7 \\
\hline
\end{tabular}

${ }^{1}$ D01 in Table 4a, D02 in Table 4b, and D03 in Table 4c denote the statistics using observations over these domains. D01 in Table 4b denotes the statistics calculated over D02 using

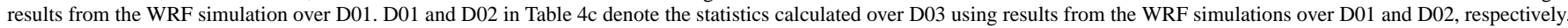

2 Obs - observation, Sim - simulation, $R$ - correlation coefficient, RMSE - root mean square error, NMB - normalized mean bias, NME - normalized mean error.

$3 \mathrm{~T} 2-2 \mathrm{~m}$ temperature, Q2 - $2 \mathrm{~m}$ specific humidity, RH2 - $2 \mathrm{~m}$ relative humidity, WS10 - $10 \mathrm{~m}$ wind speed, WD10 - $10 \mathrm{~m}$ wind direction, Precip - precipitation, SWDOWN downward shortwave radiation flux, LWDOWN - downward longwave radiation flux, OLR - outgoing radiation flux

${ }^{4}$ D03 contains no BSRN sites for shortwave and longwave radiation and also not enough data points for outgoing longwave radiation in D03. For OLR, the original reanalysis data are gridded with $2.5^{\circ} \times 1.5^{\circ}$. They have to be regridded at the $0.5^{\circ} \times 0.5^{\circ}$ over D01 and $0.125^{\circ} \times 0.125^{\circ}$ over D02 before the statistical calculation, resulting in different total numbers

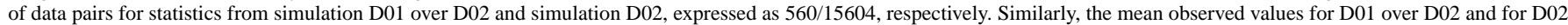
are different, with $196.9 / 199.5$ in January and 243.1/244.2 in July 2001, respectively.

$0.125^{\circ}$ over D03, the domainwide statistical performance at $0.025^{\circ}$ is slightly improved for T2. For Q2 and RH2, it is slightly worse than at $0.5^{\circ}$ but better than at $0.125^{\circ}$. WS10 is overpredicted on all days, with the smallest NMB over D03 among the three simulations at different grid resolutions over D01-D03 (i.e., $59.2 \%$ vs. $52.5 \%$ vs. $16.6 \%$ ). Using the same set of observations over D02, a moderate improvement in performance statistics is found at $0.125^{\circ}$ compared to $0.5^{\circ}$ (i.e., an NMB of $52.5 \%$ vs. $63.1 \%$ ). Using the same set of observations over D03, a slight deterioration in model performance statistics is found at $0.025^{\circ}$ as compared to model results at $0.125^{\circ}$ (i.e., an NMB of $16.6 \%$ vs. 9.9\%), but a moderate improvement is found as compared to that at $0.5^{\circ}$ (i.e., an NMB of $16.6 \%$ vs. $29.7 \%$ ). Similar overpredictions in WS10 have also been reported by Vautard et al. (2012), who intercompared several meteorological models during AQMEII. The high WS10 bias in the model simulations at all resolutions, in particular, $0.5^{\circ}$ over D01 and $0.125^{\circ}$ over D02, is due to the fact that WRF does not resolve subgrid-scale roughness elements (e.g., the surface roughness length or the friction velocity at the surface) even at the grid resolutions of $0.125^{\circ}$ and $0.025^{\circ}$. Using a corrected drag parameterization that accounts for the topographic effects, Mass and Ovens (2011) showed large and consistent improvements in the low and moderate low-level winds, and Jiménez and Dudhia (2011) showed reduced overpredictions in wind speeds over plains/valleys. The domainwide NMB is slightly better (NMB changes from $7.1 \%$ over D01 to $5.7 \%$ over D02). The model biases in daily WD10 predictions from D01 and D02 simulations are similar. The NMBs of WD10 predictions are similar at $0.5^{\circ}$ and $0.125^{\circ}$ over D02 with slightly better performance over D02, and at all three grid resolutions over D03 with slightly better performance over D03. Daily mean Precip is significantly underpredicted in the D01 and D02 simulations in the first and last weeks in January. Both underpredictions and overpredictions occur on some days over D03, especially on days with observed intensive precipitations (e.g., 1, 4, 5, 21, 23, and 27 January). For domainwide statistical performance, the NMBs of Precip are $-54.8 \%,-50.0 \%$, and $-13.2 \%$ over D01, D02, and D03, respectively. Compared to the simulations at $0.5^{\circ}$ over D02, the underprediction of Precip at $0.125^{\circ}$ is greatly reduced (NMB changes from $-66.3 \%$ to $-50.0 \%$ ). Compared to the simulations at $0.5^{\circ}$ and $0.125^{\circ}$ over D03, the underprediction in Precip at $0.025^{\circ}$ is also largely reduced, with NMBs changing from $-47.6 \%$ at $0.5^{\circ}$ and $-49.7 \%$ at $0.125^{\circ}$ to $-13.2 \%$ at $0.025^{\circ}$. The improvement in the Precip predictions over progressively nested domains demonstrates the benefits of using a fine grid resolution in simulating mesoscale events.

Compared with January, WRF performs much better for T2, Q2, WS10, WD10, and Precip over D01 in July in terms of both daily mean and performance statistics. Compared with WRF performance at $0.5^{\circ}$ over D02, the WRF simulation at $0.125^{\circ}$ over D02 slightly improves model performance in predicted T2, Q2, RH2, and WD10 in terms of both daily predictions and domainwide performance statics. Compared with the simulations at $0.5^{\circ}$ over D01 and at $0.125^{\circ}$ over D02, the simulation at $0.025^{\circ}$ over D03 gives slightly higher $\mathrm{T} 2, \mathrm{Q} 2$, and $\mathrm{RH} 2$ on most days, resulting in an improved performance, with NMBs of $-0.8 \%, 2.1 \%$, and $1.3 \%$, respectively. Compared with the performance at $0.5^{\circ}$ over D01, WS10 predictions are slightly worse on most days at $0.125^{\circ}$ over D02 and moderately worse at $0.025^{\circ}$ over D03, which is also reflected in the domainwide performance statistics (NMBs of $-2.3 \%,-13.3 \%$, and $-25.5 \%$, respectively). Compared with model predictions at $0.5^{\circ}$ over D02, the model performance of WS10 is slightly worse at $0.125^{\circ}$ over D02 with NMBs of $-10.0 \%$ and $-13.3 \%$, respectively. Compared with model predictions at $0.5^{\circ}$ and 
$0.125^{\circ}$ over D03, The model performance in WS10 over D03 at $0.025^{\circ}$ is slightly worse than that at $0.5^{\circ}$ (an NMB of $-25.5 \%$ vs. $-24.0 \%$ ) and better than that at $0.125^{\circ}$ (an NMB of $-25.5 \%$ vs. $-30.8 \%)$. The performance of WD10 over D02 is slightly improved for some days (e.g., July 5-8 and 18) as compared with that over D01, leading to a slight improvement at $0.125^{\circ}$ as compared to that at $0.5^{\circ}$ (the NMB changing from $4.2 \%$ to $2.9 \%$ ). The statistical performance of WD10 over D03 is slightly worse at $0.025^{\circ}$ as compared to at $0.5^{\circ}$ and $0.125^{\circ}$, with NMBs of $4.7 \%, 3.9 \%$, and $4.3 \%$, respectively. Compared with D01 results at $0.5^{\circ}$, daily mean Precip is overpredicted or underpredicted to a larger extent on more days at $0.125^{\circ}$ over D02. The overpredictions in Precip dominate, resulting in an NMB of $82.3 \%$ over D02 at $0.125^{\circ}$ (vs. $52.5 \%$ at $0.5^{\circ}$ ). Compared with D01 and D02 results, although large differences exist between simulated and observed Precip on some days (e.g., 5, 7, 10, 13, 14, 17, 18, and 26 July), the predicted Precip at $0.025^{\circ}$ over D03 is improved on 4 and 6 July because WRF can capture well some of the large convective precipitation events in France. The large positive and negative biases over D03 compensate each other, resulting in an improved performance with NMBs of $-33.7 \%$ at $0.025^{\circ}$ (compared to $-47.0 \%$ at $0.5^{\circ}$ and $-47.4 \%$ at $0.125^{\circ}$ over the same D03 domain).

As shown in Table $4 \mathrm{~b}$, compared with results at $0.5^{\circ}$ over D02, the use of a grid resolution of $0.125^{\circ}$ over D02 slightly improves the performance of Q2 and WD10 in both months, WS10 in January, and T2 and RH2 in July, and greatly reduces the large underpredictions in Precip in January. As shown in Table $4 \mathrm{c}$, compared with D03 results at $0.125^{\circ}$, the use of a grid resolution of $0.025^{\circ}$ slightly improves the performance of T2 and RH2 in both months, Q2 and WD10 in January, and WS10 in July and greatly reduces the large underpredictions in Precip in both months. Those improvements are due to better defined and more realistic representations of mesoscale topographic features and structures as well as corresponding atmospheric circulations as the horizontal grid resolution increases; they are consistent with several studies. For example, Mass et al. (2002) showed that the use of a finer grid resolution showed some improvement of WRF performance for some events (e.g., strong forced convection, diurnal circulations, and heavy precipitation events), $10 \mathrm{~m}$ wind, $2 \mathrm{~m}$ temperature, and sea-level pressure forecasts as grid spacing decreases from 36 to $12 \mathrm{~km}$. While Mass et al. (2002) showed that, despite more detailed and finer structure, further decreasing grid spacing from $12 \mathrm{~km}$ to $4 \mathrm{~km}$ has only small improvements in traditional model evaluation statistics (e.g., MB, RMSE, threat scores, etc.), Misenis and Zhang (2010) showed that, as the grid resolution increases from $12 \mathrm{~km}$ to $4 \mathrm{~km}$, the performance of WRF improves in terms of NMBs for RH2, WS10, and planetary boundary layer height. However, Table $4 \mathrm{~b}$ and $\mathrm{c}$ also showed that not all meteorological predictions are improved using finer grid resolutions. For example, comparing WRF at $0.125^{\circ}$ with WRF at $0.5^{\circ}$ over D02 (Table 4b), slight deteriorations oc- cur for a few variables such as SWDOWN in both months, LWDOWN, T2, RH2 in January, OLR and WS10 in July, and much worse performance occurs for Precip. In addition to horizontal grid resolutions, the accuracy of the meteorological predictions depends on many other factors including the accuracy of the input data such as land use, and boundary conditions, the accuracy of model algorithms for all major meteorological processes under all meteorological and topographical conditions, as well as the uncertainties in model configurations (e.g., vertical grid resolution, nesting options, and data assimilation options). The inaccuracies and limitations in those other factors at a fine grid resolution may offset the benefit of the fine grid resolution, resulting in little improvements or even worse in some meteorological variables.

\subsection{Temporal variations at specific sites}

\subsection{Description of selected sites}

The observations of precipitation and other meteorological variables such as T2, Q2, WS10, and WD10 come from different databases (i.e., ECA\&D and NCEP, respectively), and no observations of all these variables were available at the same sites. Ten sites and five co-located sites are selected for detailed temporal analysis for T2, Q2, and WS10. Eight of the ten sites are selected for evaluation of vertical profiles of $T, \mathrm{~T}_{\mathrm{d}}$, WS, and WD against sounding data. Eight sites are selected for detailed analysis for precipitation. Table 5 summarizes the major characteristics of the selected sites. Among the ten NCEP sites selected for analysis of T2, Q2, and WS10, three sites (Paris Charles de Gaulle airport, Paris Orly airport, and Melun, France) are in D03, two sites (Milan 1/Milan 2, Italy and Bilbao, Spain) are in D02 but outside D03, and five sites (Stockholm 1, Sweden; London 1/London 2, UK; Düsseldorf 1/Düsseldorf 2, Germany; Liberec, Czech Republic; and Madrid 1/Madrid 2, Spain) are in D01 but outside D02 and D03. Among the eight sites selected for a detailed analysis of Precip, three sites (Pris-14E, Brétignysur-Orge, and Chartres-Champhol, France) are in D03, two sites (Milan, Italy and San Sebastián-Igueldo, Spain) are in D02 but outside D03, and three sites (Stockholm, Sweden; Görlitz, Czech Republic; and Düsseldorf, Germany) are in D01 but outside D02 and D03. If other monitoring sites are within a $30 \mathrm{~km}$ radius of these selected sites, they are considered to be co-located with the selected sites. The observations from co-located sites are also plotted even though the simulated results at selected and co-located sites fall into the same grid cell in the respective simulation domain. Among the eight sites selected for precipitation analysis, six sites are co-located with the sites selected for analysis of T2, Q2, and WS10. Stockholm is co-located with Stockholm 1. Düsseldorf is co-located with Düsseldorf 1/Düsseldorf 2, Germany. Görlitz is co-located with Liberec, the Czech Republic. Pris-14E and Brétigny-sur-Orge are co-located with 
Paris Orly airport and Melun, France, respectively. Milan is co-located with Milan 1/Milan 2, Italy.

These sites are selected from seven countries for their geographical and topographical representations. They are classified into urban (Paris Orly/Pris-14E, Melun/Brétignysur-Orge, Chartres-Champhol, Charles de Gaulle, Milan 1/Milan 2, Bilbao/Avenida Gasteiz, Madrid 1/Madrid 2, San Sebastián-Igueldo, Liberec/Görlitz, London 1/London 2 and Stockholm/Stockholm 1) and suburban background (Düsseldorf 1/Düsseldorf 2 and Düsseldorf). Among these sites, mountain, hill, and high plain sites include Madrid 1/Madrid 2, Bilbao/Avenida Gasteiz, Liberec/Görlitz, and San Sebastián-Igueldo with above sea levels of 594, 517, 350 , and $252 \mathrm{~m}$, respectively. The altitude, location, and topography affect the climate conditions at these sites. Climatic conditions at selected sites include Western European oceanic climate (i.e., Melun/Melun/Brétigny-sur-Orge, Paris Orly/Pris-14E, Charles de Gaulle, and Chartres-Champhol, London 1/London 2, and Bilbao/Avenida Gasteiz, San Sebastián-Igueldo), continental Mediterranean climate (Madrid 1/Madrid 2), humid continental climate (Liberec/Görlitz, Stockholm/Stockholm 1), humid subtropical climate (Milan 1/Milan 2 and Milan), and warm temperate climate (e.g., Düsseldorf). In addition to the representativeness of those sites in terms of climatic, geographical, and topographical characteristics, data availabilities and completeness are also part of the consideration for site selections.

\subsection{Simulations over D01 at a horizontal grid resolution of $0.5^{\circ}$}

Figures 8-9 show simulated and observed hourly T2 at the ten sites. In January, WRF over D01 captures T2 well in terms of both magnitudes and diurnal variations at London 1/London 2, Charles de Gaulle, Paris Orly, and Melun. At Stockholm 1/Stockholm 2, Düsseldorf 1/Düsseldorf 2, and Madrid 1/Madrid 2, WRF over D01 simulates T2 well on most days with large underpredictions on a few days, e.g., January 18-21 when snow occurred at Düsseldorf 1/Düsseldorf 2 and Stockholm 1/Stockholm 2, and January $7,15,16$, and 18 when the weather was cold and dry with relatively low winds at Madrid 1/Madrid 2. At Stockholm $1 /$ Stockholm 2, snow occurred on 18 out of 31 days (1-2, 6-7, 10-12, 17-24, 27, 29, and 31 January) with the lowest observed T2 on 15 January 2001. WRF is able to simulate the decreasing trend in $\mathrm{T} 2$ from January 8 to 16 , but it fails to predict the lowest $\mathrm{T} 2$ of $-11^{\circ} \mathrm{C}$ on 15 January and the second and third lowest $\mathrm{T} 2$ of $-10.5^{\circ} \mathrm{C}$ and $-10.0^{\circ} \mathrm{C}$ on 16 and 20 January, respectively. At Düsseldorf 1/Düsseldorf 2, while WRF is able to simulate the rapid decreasing trend and gradient in T2 from January 5 to 16 and the second coldest $\mathrm{T} 2$ on January 17, it fails to predict the lowest temperature of $-8.0^{\circ} \mathrm{C}$ on 16 January (which is the coldest day of 2001 based on weather records at Düsseldorf) and low T2 on January $12,15,28$, and 29 . WRF predicts a persis- tent snow cover 17-24 January at Stockholm 1/Stockholm 2 and 18-21 January at Düsseldorf 1 and Düsseldorf 2, resulting in significantly lower $\mathrm{T} 2$ values than those observed. As described by Gilliam et al. (2007), this behavior may indicate some limitations of the snow melting treatment and surface energy balance representation in WRF that gives a slower snowmelt, resulting in higher snow cover and lower temperature and precipitation at this site. At Liberec, WRF overpredicts T2 during the first and fourth weeks of January and underpredicts T2 in the third week. At Milan 1/Milan 2, large underpredictions occur on most days in January. Snow events occurred in Milan on 2 and 17-18 January 2001, and rain/drizzle and fog occurred 14-16 days in this month, during which WRF failed to reproduce the observed temperatures. At Bilbao, WRF overpredicts T2 on most days. The poor model performance in $\mathrm{T} 2$ at the mountain sites (e.g., Bilbao and Liberec) or sites in the large urban centers (e.g., Milan 1/Milan 2) indicates the limitation of the model in simulating meteorological variables in complex terrain such as mountains where the air-surface fluxes and cloud formation are affected by special mountainous weather patterns, or urban clusters where the air-surface fluxes in the boundary layer are largely affected by urban heat island effects, as well as the snow/rain/drizzle/fog events. At most sites, MBs from the WRF simulation over D01 are within $\pm 1^{\circ} \mathrm{C}$. Larger MBs occur at Stockholm 1, London 2, Milan 1, and Bilbao for the reasons mentioned above.

Compared with January, WRF performs much better at all sites, particularly at Milan 1/Milan 2 in July, although relatively large discrepancies between predictions and observations remain at the two mountain sites: Bilbao and Liberec. Observed summer temperatures at all sites exhibit a stronger diurnal variation than winter temperatures, particularly at Madrid 1/Madrid 2 and Bilbao, due to their high altitudes and/or dry climate. Such a strong diurnal variation at all sites is well reproduced by WRF. WRF gives lower T2 on all days at Bilbao but higher T2 on some days at Liberec, likely due to inaccurate predictions in shortwave radiation, cloud formation, and air-surface heat fluxes at those sites. The nighttime temperatures at Stockholm 1/Stockholm 2 are overpredicted compared to observations at Stockholm 2 but underpredicted compared to observations at Stockholm 1. The nighttime temperatures at other urban sites such as Madrid 1/Madrid 2, Milan 1/Milan 2, and Paris Orly are generally underpredicted due to a poor representation of urban canopy and urban heat island in the default treatments of WRF. Using WRF coupled with a single-layer urban canopy model (UCM) for energy and momentum exchange between the urban surface and the atmosphere, several studies showed large improvement in simulated near-surface air temperature and relative humidity during nighttime (e.g., Chen et al., 2004; Shrestha et al., 2009; Kusaka et al., 2012; Kim et al., 2012). This is because the UCM can provide a more realistic energy balance of the urban region, via parameterizations of street canyons, building wall/roof, road surfaces, and anthropogenic heating. 
Table 5. Characteristics of sites selected for temporal analysis.

\begin{tabular}{|c|c|c|c|c|c|c|c|}
\hline Country & Site name & $\begin{array}{l}\text { Site ID } \\
\text { (network) }\end{array}$ & Site Type & Latitude & Longitude & Elevation $(\mathrm{m})$ & Characteristics \\
\hline Czech Republic & Liberec/Görlitz & $\begin{array}{l}11603 / \\
000484 \\
\text { (ECA\&D) }\end{array}$ & Urban & $50.77^{\circ} \mathrm{N} / 51.16^{\circ} \mathrm{N}$ & $\begin{array}{l}15.02^{\circ} \mathrm{E} / \\
14.95^{\circ} \mathrm{E}\end{array}$ & 350 & $\begin{array}{l}\text { Located in the fifth-largest city surrounded by the Jizera hills } \\
\text { and mountains. Historically known for its textile industry, the } \\
\text { Liberec region consists primarily of machinery industries, glass } \\
\text { and plastic. It has a humid continental climate with warm sum- } \\
\text { mers and no dry season. The temperature varies from }-6^{\circ} \mathrm{C} \text { to } \\
24^{\circ} \mathrm{C} \text { and is rarely below }-13^{\circ} \mathrm{C} \text { or above } 31^{\circ} \mathrm{C} \text {. }\end{array}$ \\
\hline \multirow[t]{4}{*}{ France } & $\begin{array}{l}\text { Melun / Melun/ } \\
\text { Brétigny-Sur-Orge }\end{array}$ & $\begin{array}{l}\text { 7153/ } \\
\text { FR04069/ } 000764 \\
\text { (NCEP/ } \\
\text { AirBase \&BDQA/ ECA\&D) }\end{array}$ & Urban & $\begin{array}{l}48.62^{\circ} \mathrm{N} / 48.54^{\circ} \mathrm{N} / \\
48.60^{\circ} \mathrm{N}\end{array}$ & $\begin{array}{l}2.68^{\circ} \mathrm{E} / \\
2.66^{\circ} \mathrm{E} / \\
2.33^{\circ} \mathrm{E}\end{array}$ & 56 & $\begin{array}{l}\text { Located in the southeastern suburbs of Paris ( } \sim 50 \mathrm{~km} \text { from } \\
\text { Paris). Paris has the typical Western European oceanic climate, } \\
\text { with mild, moderately wet, and light rainfall throughout the } \\
\text { year. Summer days are warm with average temperatures of } 15- \\
25^{\circ} \mathrm{C} \text {. Winter is cold but above freezing }\left(>7^{\circ} \mathrm{C} \text { ), with scarce }\right. \\
\text { sunshine, light night frosts, and light snow or flurries. }\end{array}$ \\
\hline & Paris Orly/Pris-14E & $\begin{array}{l}7149 / \\
000038 \\
\text { (NCEP/ECA\&D) }\end{array}$ & Urban & $48.72 \mathrm{~N} / 48.82 \mathrm{~N}$ & $\begin{array}{l}2.38 \mathrm{E} / \\
2.34 \mathrm{E}\end{array}$ & 89 & $\begin{array}{l}\text { Located in the south of Paris. It is the busiest French airport for } \\
\text { domestic traffic and the second busiest French airport overall in } \\
\text { terms of passenger traffic. }\end{array}$ \\
\hline & Chartres-Champhol & $\begin{array}{l}000768 \\
\text { (ECA\&D) }\end{array}$ & Urban & $48.46^{\circ} \mathrm{N}$ & $1.50^{\circ} \mathrm{E}$ & 155 & Located in north central France, about $90 \mathrm{~km}$ southwest of Paris \\
\hline & $\begin{array}{l}\text { Paris Charles de Gaulle/ } \\
\text { Tremblay-En-France }\end{array}$ & $\begin{array}{l}\text { 07157/FR04319 } \\
\text { (NCEP/AirBase \& BDQA) }\end{array}$ & Urban & $49.02^{\circ} \mathrm{N}$ & $2.53^{\circ} \mathrm{E}$ & 65 & $\begin{array}{l}\text { Located in the Paris Charles de Gaulle airport in northern } \\
\text { France, about } 27.3 \mathrm{~km} \text { northeast of Paris }\end{array}$ \\
\hline Germany & $\begin{array}{l}\text { Düsseldorf } 1 \text { /Düsseldorf } 2 \\
\text { Düsseldorf/ Düsseldorf-Lörick }\end{array}$ & $\begin{array}{l}\text { 10400/ } \\
\text { EDDL/ } \\
\text { 000479/ DENW071 } \\
\text { (NCEP/ } \\
\text { NCEP/ ECA\&D)/AirBase }\end{array}$ & $\begin{array}{l}\text { Suburban } \\
\text { background }\end{array}$ & $\begin{array}{l}51.28^{\circ} \mathrm{N} / 51.28^{\circ} \mathrm{N} / 51.30^{\circ} \\
51.25^{\circ} \mathrm{N}\end{array}$ & $\begin{array}{l}6 / 78^{\circ} \mathrm{E} / \\
6.78^{\circ} \mathrm{E} / \\
6.77^{\circ} \mathrm{E} / \\
6.73^{\circ} \mathrm{E}\end{array}$ & 38 & $\begin{array}{l}\text { Located in the center of the Rhine-Ruhr metropolitan region } \\
\text { in northwestern Germany. Düsseldorf has warm temperate cli- } \\
\text { mate, featuring cold winters and warm summers, with an aver- } \\
\text { age yearly temperature of } 23.5^{\circ} \mathrm{C} \text {, calm winds, and } \sim 77 \mathrm{~cm} \text { of } \\
\text { rainfall. }\end{array}$ \\
\hline Italy & $\begin{array}{l}\text { Milan1/ } \\
\text { Milan 2 } \\
\text { Milan }\end{array}$ & $\begin{array}{l}\text { 16080/ } \\
\text { LIML/000173 } \\
\text { (NCEP/ } \\
\text { NCEP/ ECA\&D) }\end{array}$ & Urban & $\begin{array}{l}45.43^{\circ} \mathrm{N} / 45.43^{\circ} \mathrm{N} / \\
45.48^{\circ} \mathrm{N}\end{array}$ & $\begin{array}{l}9.28^{\circ} \mathrm{E} / \\
9.28^{\circ} \mathrm{E} / \\
9.20^{\circ} \mathrm{E}\end{array}$ & 122 & $\begin{array}{l}\text { Located in the second-largest city in northern Italy. Milan has } \\
\text { a humid subtropical climate with sultry, humid summers (peak } \\
\left.\text { temperatures of } 34^{\circ} \mathrm{C}\right) \text { and cold, rainy, and snowy winters with } \\
\text { average temperatures below freezing }\left(-2^{\circ} \mathrm{C}\right) \text {. }\end{array}$ \\
\hline \multirow[t]{3}{*}{ Spain } & Bilbao/ Avenida Gasteiz & $\begin{array}{l}\text { LEVT/ ES1502A } \\
\text { (NCEP/ } \\
\text { AirBase) }\end{array}$ & Urban & $42.88^{\circ} \mathrm{N} / 42.85^{\circ} \mathrm{N}$ & $\begin{array}{l}2.73^{\circ} \mathrm{W} / \\
2.68^{\circ} \mathrm{W}\end{array}$ & 517 & $\begin{array}{l}\text { Located in one of the most populous metropolitan areas in } \\
\text { northern Spain. Many manufacturing companies have opera- } \\
\text { tions in this area (automobiles, tires, games, cookies, pasta, and } \\
\text { flour). Bilbao has an oceanic climate due to its proximity to the } \\
\text { Bay of Biscay, with abundant precipitation occurring through- } \\
\text { out the year. Summer and winter are mild, with summer average } \\
\text { maximum temperatures of } 25-26^{\circ} \mathrm{C} \text { and winter average mini- } \\
\text { mum temperatures of } 6-7^{\circ} \mathrm{C} \text {. Gasteiz has a mild humid temper- } \\
\text { ate climate with warm summers and no dry season. The annual } \\
\text { summer high temperature is } 26.7^{\circ} \mathrm{C} \text {, and the winter low tem- } \\
\text { perature is } 1.1^{\circ} \mathrm{C} \text {. }\end{array}$ \\
\hline & $\begin{array}{l}\text { Madrid } 1 \\
\text { /Madrid } 2\end{array}$ & $\begin{array}{l}8221 / \\
\text { LEMD } \\
\text { (NCEP) }\end{array}$ & Urban & $40.45^{\circ} \mathrm{N}$ & $3.55^{\circ} \mathrm{W}$ & 594 & $\begin{array}{l}\text { Located in the capital and the largest city in Spain. The Madrid } \\
\text { region features a continental Mediterranean climate with cold } \\
\text { winters because of its high altitude, including sporadic snow- } \\
\text { falls, minimum temperatures often below freezing, hot and dry } \\
\text { summers with temperatures above } 30^{\circ} \mathrm{C} \text { and precipitation in } \\
\text { fall and spring. }\end{array}$ \\
\hline & San Sebastian-Igueldo & $\begin{array}{l}000234 \\
\text { (ECA\&D) }\end{array}$ & Urban & $43.31^{\circ} \mathrm{N}$ & $2.04^{\circ} \mathrm{W}$ & 252 & $\begin{array}{l}\text { Located in northeastern Spain on the coast of the Bay of Biscay } \\
\text { and } 20 \mathrm{~km} \text { away from the French border. It has an oceanic cli- } \\
\text { mate with warm summers (high temperatures of } 25.2^{\circ} \mathrm{C} \text { ) and } \\
\text { winters (low temperatures of } 4.4^{\circ} \mathrm{C} \text { ), and some rainfall in all } \\
\text { months (annual total precipitation of } 1738 \mathrm{~mm} \text { ). }\end{array}$ \\
\hline Sweden & $\begin{array}{l}\text { Stockholm/ } \\
\text { Stockholm 1/ } \\
\text { Stockholm } 2 / \\
\text { Södermalm }\end{array}$ & $\begin{array}{l}000010 / \\
02484 / \\
2469 / \\
\text { SE0022A } \\
\text { (ECA\&D/ } \\
\text { NCEP/ } \\
\text { AirBase) }\end{array}$ & Urban & $\begin{array}{l}59.35^{\circ} \mathrm{N} / 59.57^{\circ} \mathrm{N} / \\
59.18^{\circ} \mathrm{N} / 59.32^{\circ} \mathrm{N}\end{array}$ & \multicolumn{2}{|c|}{$\begin{array}{l}18.05^{\circ} \mathrm{E} / 18.10 \% 2 \mathrm{E} \\
/ \\
17.92^{\circ} \mathrm{E} / \\
18.06^{\circ} \mathrm{E}\end{array}$} & $\begin{array}{l}\text { The capital and the largest city of Sweden and constitutes the } \\
\text { most populated urban area in Scandinavia. The city is situated } \\
\text { on the water in the Riddarfjärden bay, with } 30 \% \text { of the city area } \\
\text { composed of waterways. Stockholm has a hemiboreal humid } \\
\text { continental climate, having summer average daytime tempera- } \\
\text { tures of } 20-22^{\circ} \mathrm{C} \text { and snowy winters with average temperatures } \\
\text { of }-5 \text { to } 1^{\circ} \mathrm{C} \text {. Annual precipitation is } 539 \mathrm{~mm} \text { with } \sim 170 \text { wet } \\
\text { days and light to moderate rainfall throughout the year. Daytime } \\
\text { is short }(\sim 6 \mathrm{~h}) \text { in winter and long }(\sim 18 \mathrm{~h}) \text { in summer due to its } \\
\text { high latitudes. }\end{array}$ \\
\hline UK & $\begin{array}{l}\text { London } 1 / \\
\text { Landon } 2 / \\
\text { London Bloomsbury }\end{array}$ & $\begin{array}{l}3779 / \\
3781 / \\
\text { GB0566A } \\
\text { (NCEP/ } \\
\text { NCEP/ } \\
\text { AirBase) }\end{array}$ & Urban & $\begin{array}{l}51.52 \mathrm{~N} / 51.30 \mathrm{~N} / \\
51.52^{\circ} \mathrm{N}\end{array}$ & $\begin{array}{l}0.1^{\circ} \mathrm{W} / \\
0.09^{\circ} \mathrm{W} / \\
0.12^{\circ} \mathrm{W}\end{array}$ & 39 & $\begin{array}{l}\text { Located in the largest urban area in UK. London has a tem- } \\
\text { perate oceanic climate, with chilly, snowy winters with average } \\
\text { low temperatures }>-4^{\circ} \mathrm{C} \text {, warm to hot summers with average } \\
\text { temperatures of } 24^{\circ} \mathrm{C} \text {, and precipitation of } 83.4 \mathrm{~mm} \text {. }\end{array}$ \\
\hline
\end{tabular}

The $\mathrm{CO}_{2}$ domes also increase surface and near-surface temperature (Jacobson, 2010), which are not simulated in WRF. At most sites, MBs from the WRF simulation over D01 are within $\pm 1^{\circ} \mathrm{C}$. Larger MBs occur at London 2, Liberec, Milan 1 , and Bilbao for the reasons mentioned above.

Figures 10-11 show simulated and observed hourly Q2 at the ten sites. Observed Q2 is generally well reproduced at most sites in both months (note that no observations were available at Stockholm 1/Stockholm 2, London 1/London 2 , and Bilbao in January and at Stockholm 1/Stockholm 2 and Bilbao in July), with relatively poorer performance at several high altitude sites (e.g., Liberec, Madrid 1/Madrid 2) and at Milan 1/Milan 2. In particular, the underpredic- tions in Q2 at Düsseldorf 1/Düsseldorf 2 are associated with the snow events during 18-21 January 2001. In July, WRF gives relatively large underpredictions in Q2 at Milan 1/Milan 2 throughout the month, during which thunderstorms occurred on 14 days (i.e., 3, 7-10, 14-16, 18-20, 24, and 2729 July). The thunderstorms resulted in a very high humidity that could not be reproduced by the WRF simulations. These results illustrate the model's difficulty in simulating water balance under humid subtropical summer climate conditions. At most sites, MBs from the WRF simulation over D01 are within $\pm 0.6 \mathrm{~g} \mathrm{~kg}^{-1}$, which indicates a very good performance. Larger biases occur at Milan 1 in both months for the reason mentioned above. 

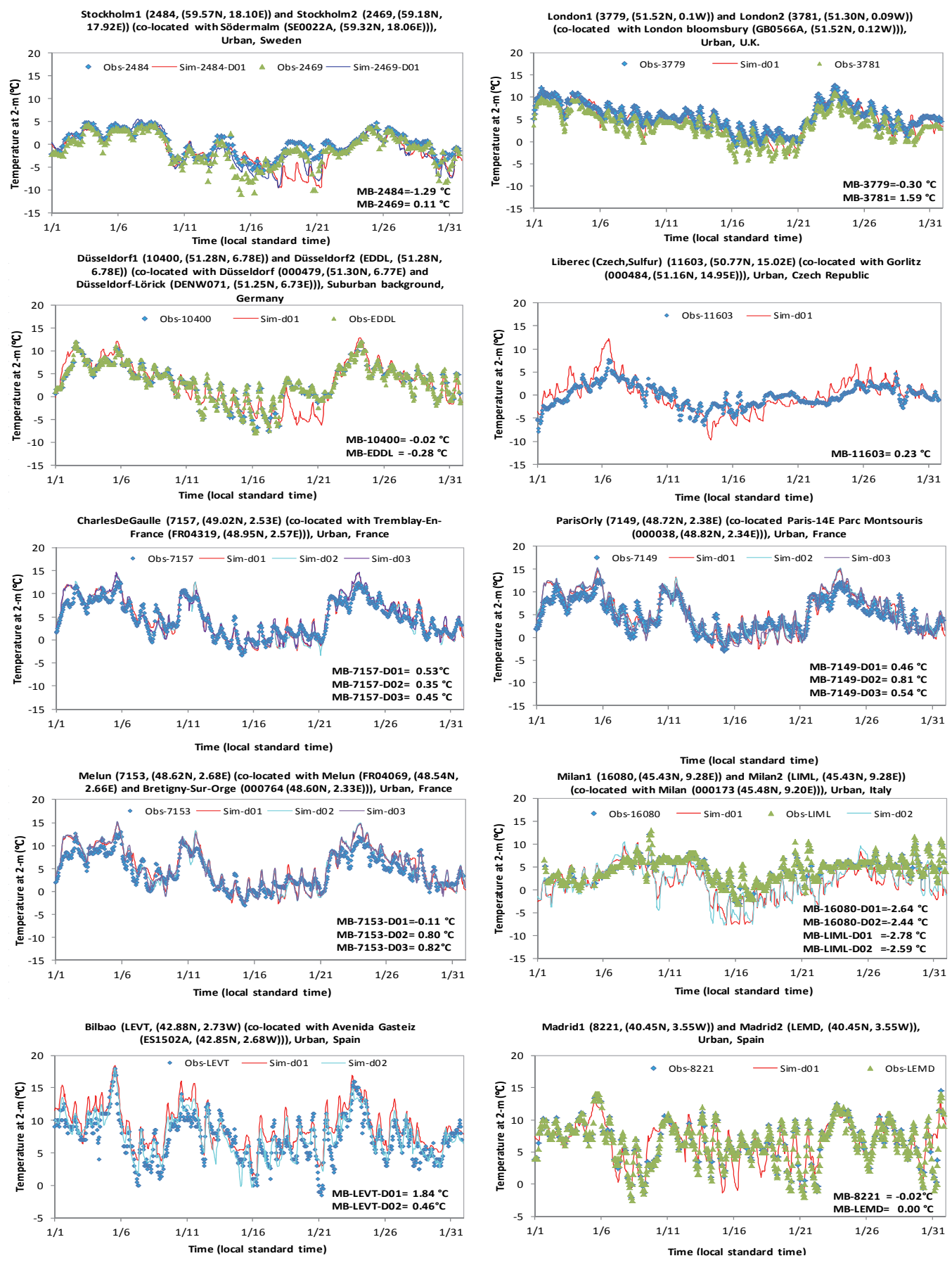

Fig. 8. Simulated and observed $2 \mathrm{~m}$ temperatures in January 2001 at selected sites.

Figures 12-13 show simulated and observed hourly WS10 at the ten sites. In January, WRF captures WS10 well in terms of both hourly variations and magnitudes at London 1/London 2, Paris Charles de Gaulle, Paris Orly, and Melun. At the remaining sites, WRF simulates well the temporal variations but tends to overpredict the magnitudes of WS10, particularly at Stockholm 1/Stockholm 2, Düsseldorf 1/Düsseldorf
2, and Milan 1/Milan 2, due mainly to WRF's incapability of resolving subgrid-scale topography at these sites and light wind conditions at Stockholm 1/Stockholm 2 and Milan 1/Milan 2. The inability of WRF to simulate the stable boundary layer has also been found by Vautard et al. (2012). In July, WRF reproduces WS10 well at Stockholm 1/Stockholm 2, Düsseldorf 1/Düsseldorf 2, Liberec, and Bilbao, 

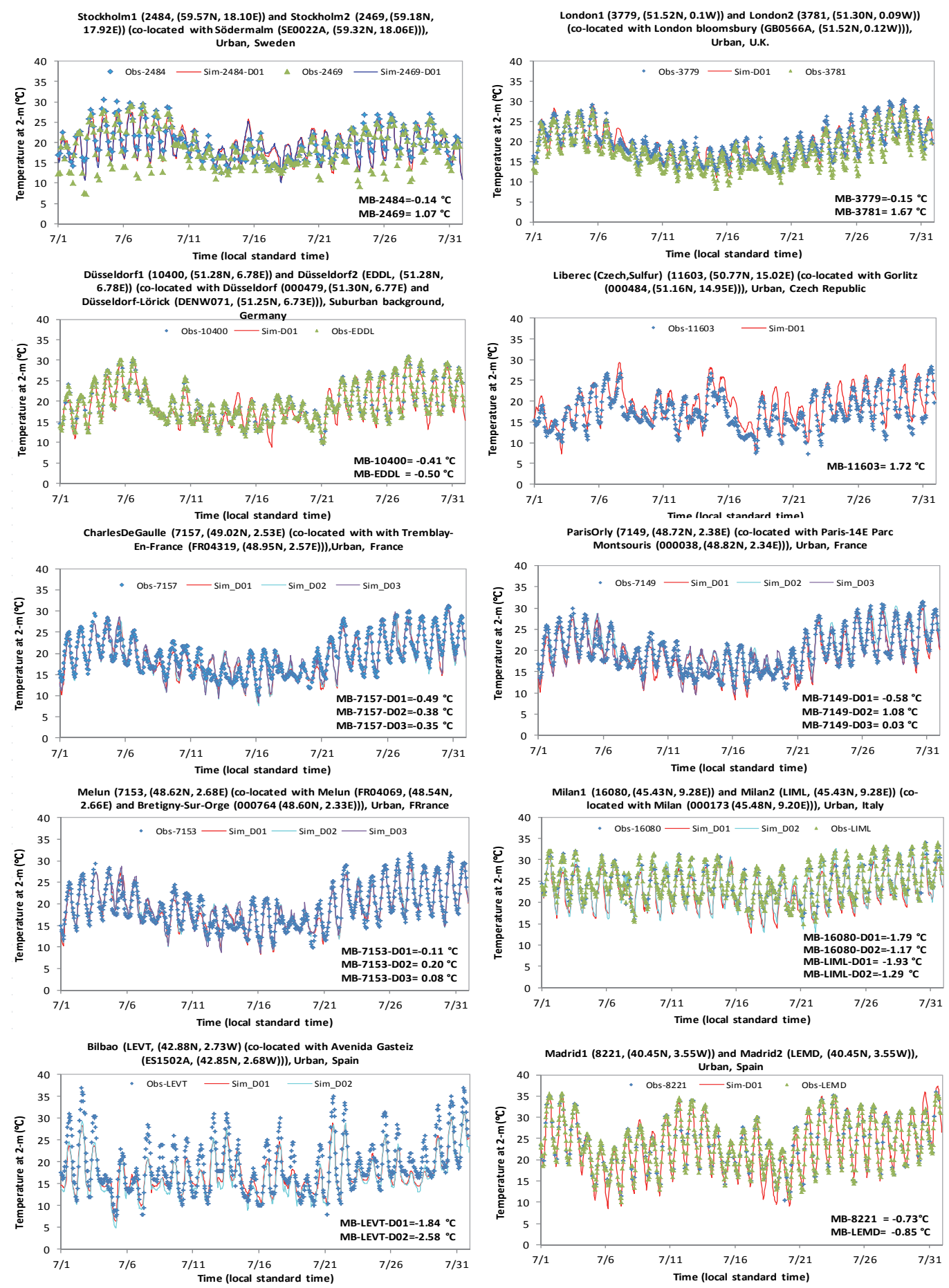

Fig. 9. Simulated and observed $2 \mathrm{~m}$ temperatures in July 2001 at selected sites.

but significantly underpredicts those at London $1 /$ London 2, Paris Charles de Gaulle, Paris Orly, and Melun, due in part to the model's limitation in capturing the wind speeds and patterns as well as heat balance in the boundary layer over large urban centers that often have a complex topography and structures and that are affected by many human- induced factors such as urban heat islands and $\mathrm{CO}_{2}$ domes. At Madrid 1/Madrid 2, the observations at the two co-located sites (Madrid 1 (or 8221) and Madrid 2 (or LEMD)) vary significantly: WRF gives better agreement with observations at Madrid 2 but significantly underpredicts observations at Madrid 1. At Milan 1/Milan 2, the observations at the two 

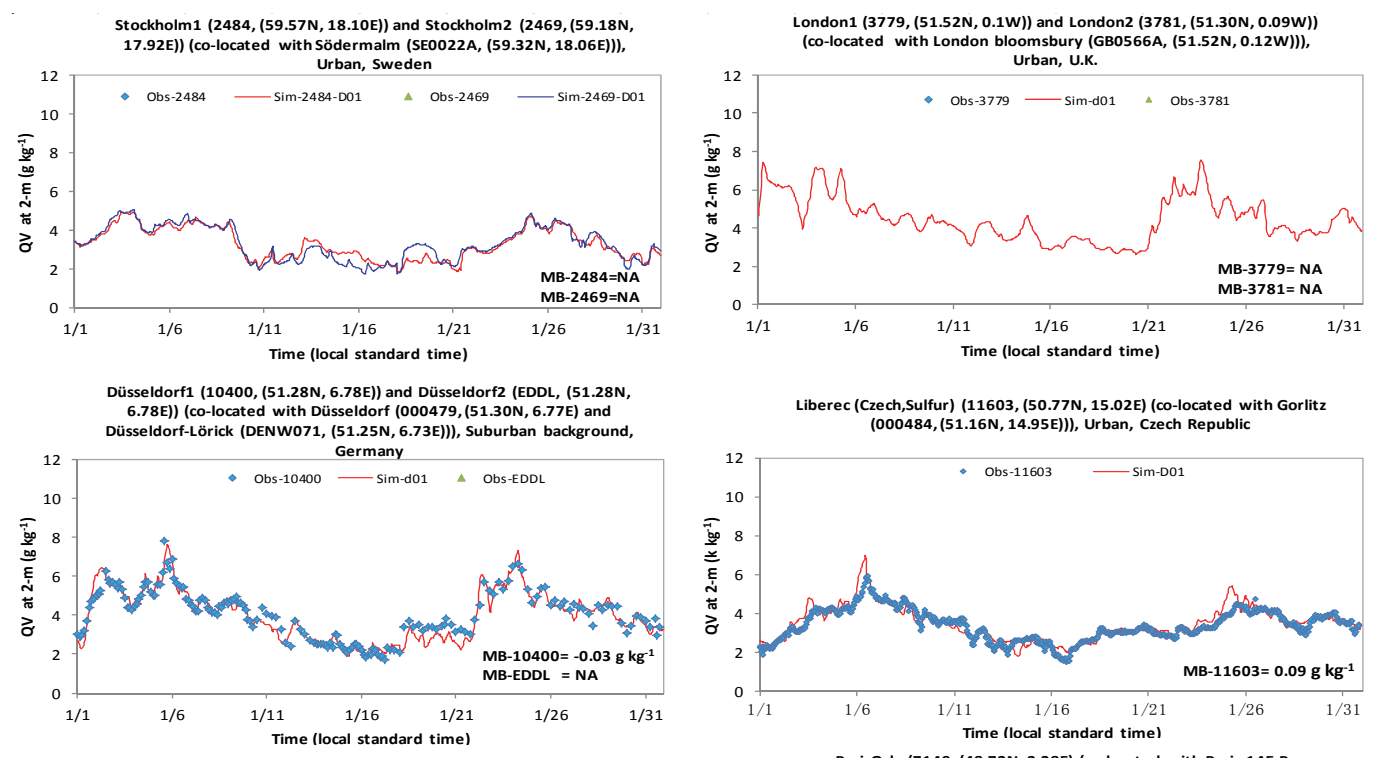

CharlesDeGaulle $(7157,(49.02 \mathrm{~N}, 2.53 \mathrm{E})$ (co-located with with TremblayEn-France (FR04319, (48.95N, 2.57E))), Urban, France
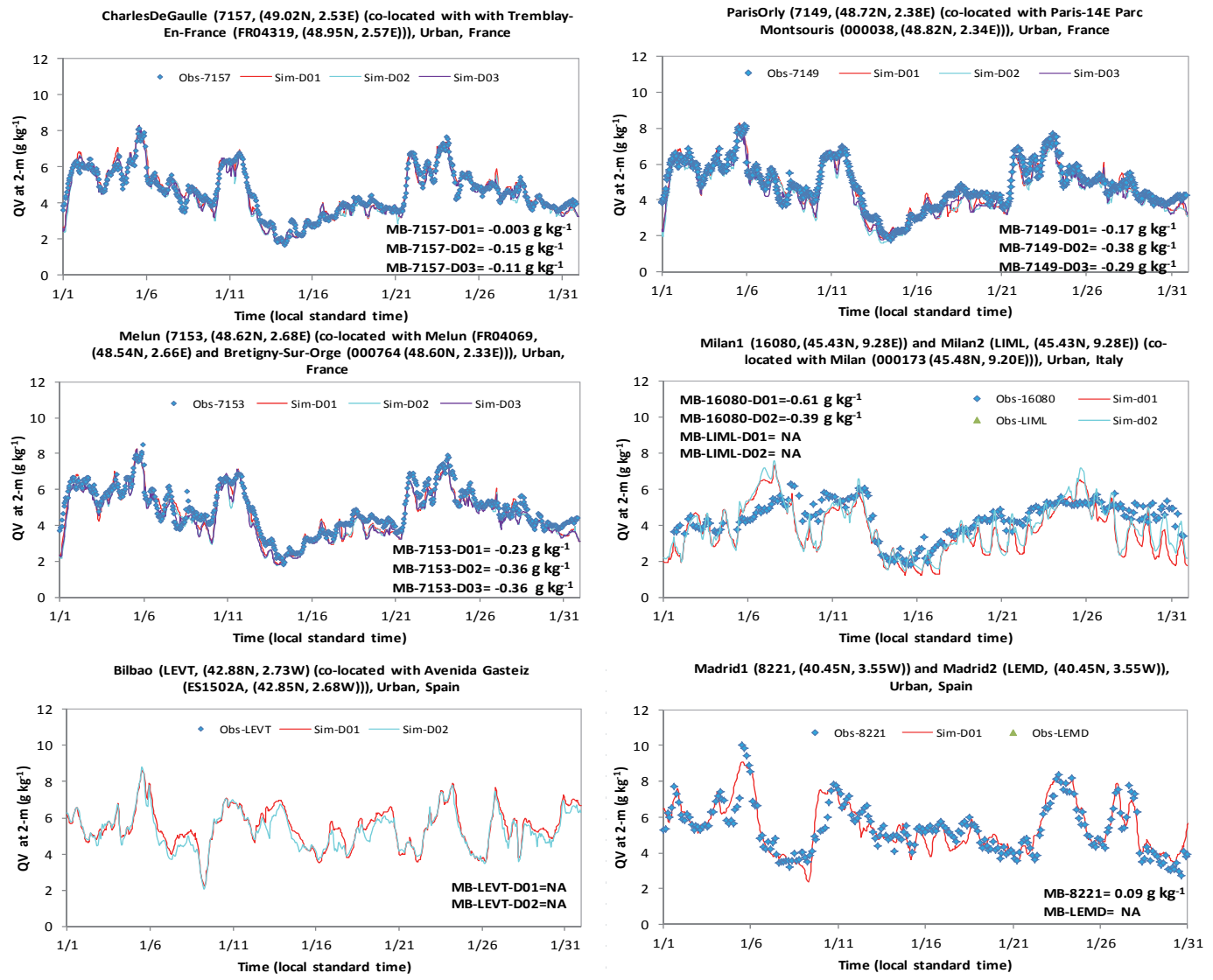

Fig. 10. Simulated and observed $2 \mathrm{~m}$ specific humidity in January 2001 at selected sites. Statistics is not available (NA) at a few sites where observations were not available.

co-located sites (Milan 1 (or 16080) and Milan 2 (or LIML)) also vary largely, with higher winds at Milan 1 . WRF gives better agreement with observations at Milan 2 but underpredicts observations at Milan 1. These comparisons indicate that the uncertainties in observations contribute to model bi- ases. MBs from the WRF simulation over D01 are larger than $1 \mathrm{~m} \mathrm{~s}^{-1}$ at most sites in January and at London 1, Liberec, Paris Charles de Gaulle, Paris Orly, Milan 2, and Madrid 1 in July, indicating a poor performance in WS10. The corresponding simulated and observed hourly WD10 at these sites 

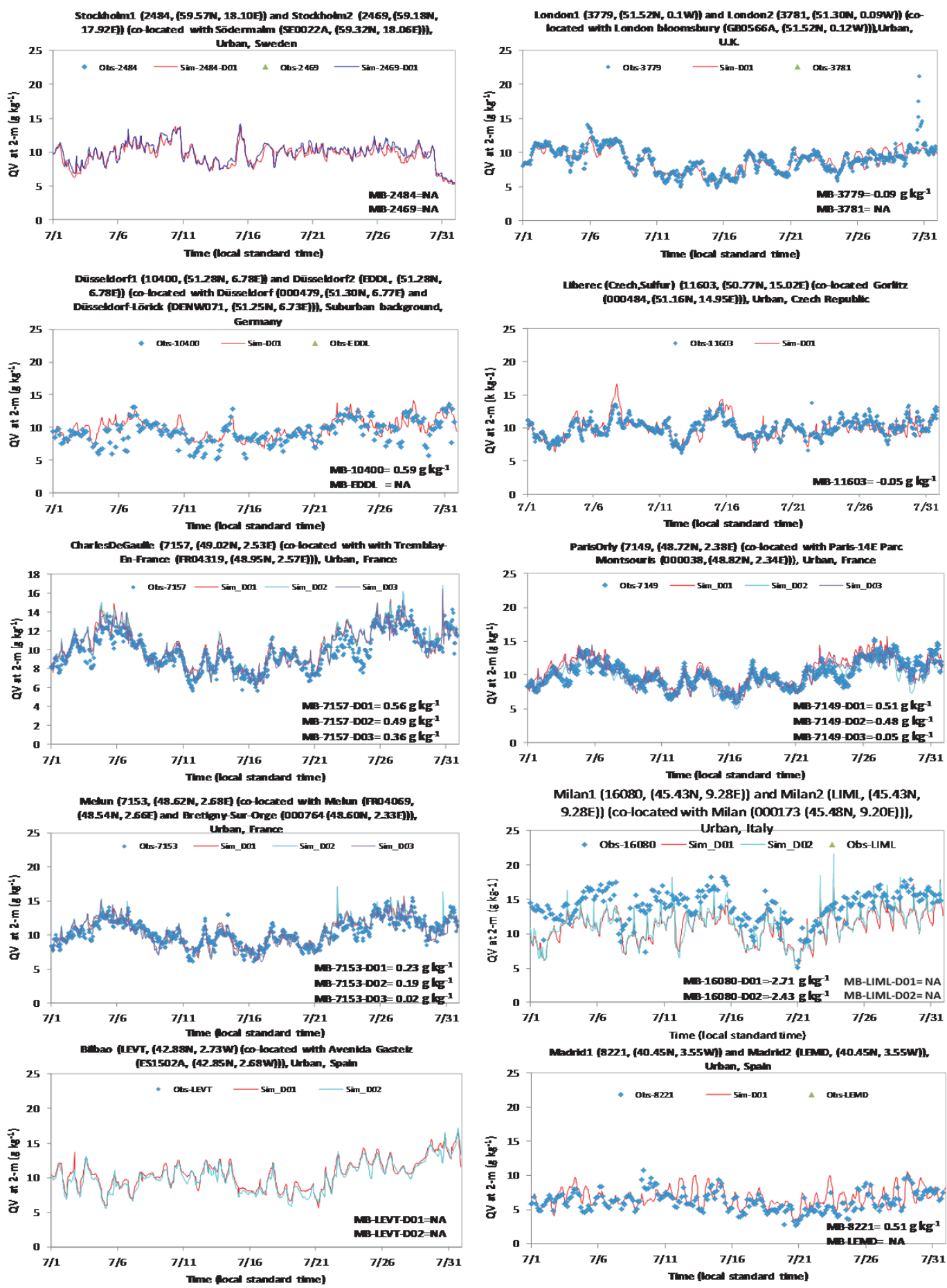

Fig. 11. Simulated and observed $2 \mathrm{~m}$ specific humidity in July 2001 at selected sites. Statistics is not available (NA) at a few sites where observations were not available.

are shown in Figs. 14-15. While simulated WD10 generally captures observations and diurnal variation at most sites in both months, large deviations occur during some hours/days (e.g., Düsseldorf 1, Melun, Milan 1, and Milan 2 in July and Liberec in both months). MBs from the WRF simulation over
D01 are larger than $\pm 10^{\circ}$ at many sites (e.g., Düsseldorf 1, Liberec, Melun, Milan 1, Milan 2, Madrid 1, and Madrid 2) in January and all sites except for Stockholm 1 and Madrid 1 in July, indicating a poor performance in WD10. 

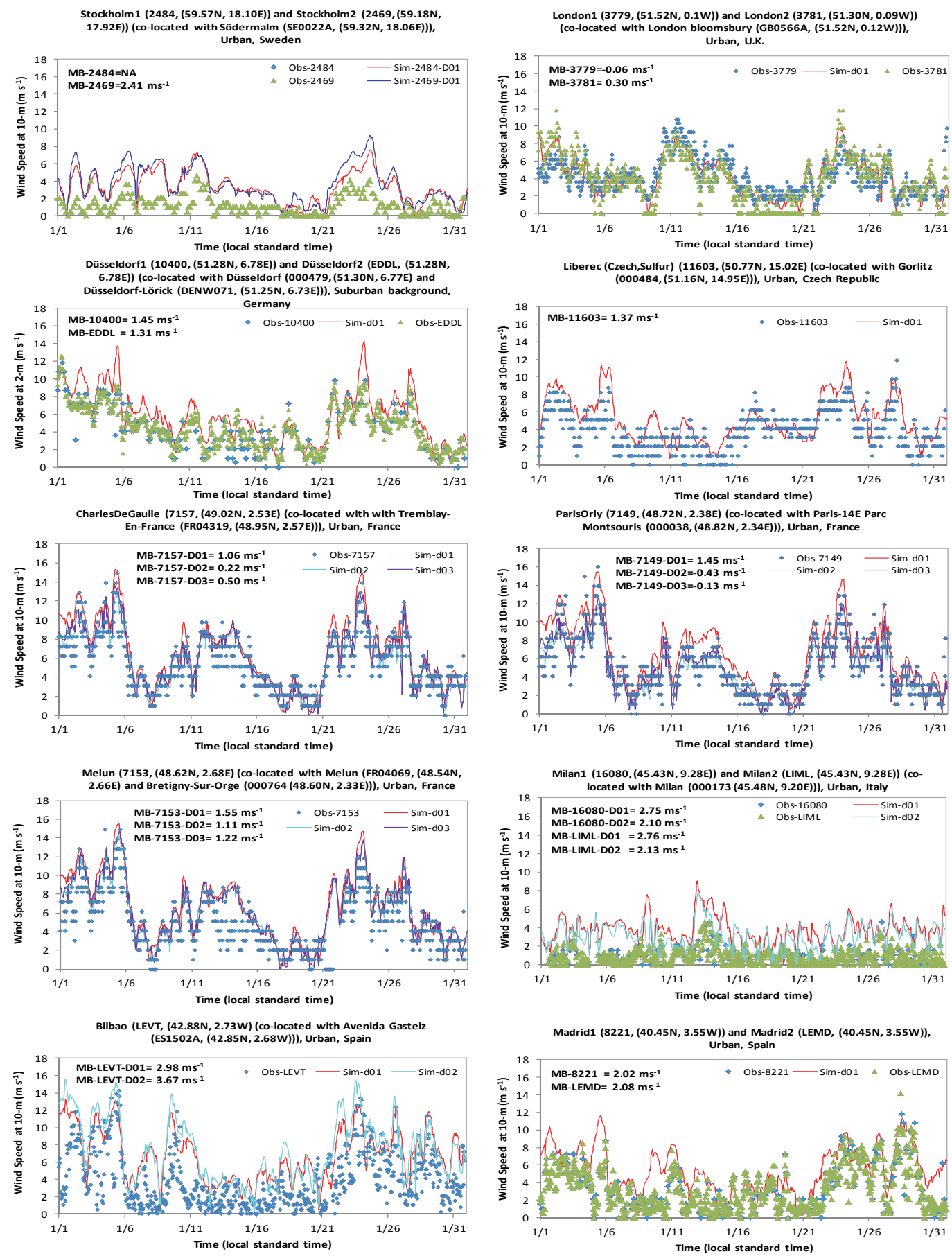

Fig. 12. Simulated and observed $10 \mathrm{~m}$ wind speed in January 2001 at selected sites. Statistics is not available (NA) at one site (Stockholm 1$)$ where observations were not available.

Figures 16-17 show site-specific simulated and observed daily Precip at the eight sites. Observed Precip varies largely among these sites and between January and July at the same site, particularly at the high altitude sites (e.g., Görlitz, San Sebastián-Igueldo). In January, WRF is able to capture precipitation events at all sites with exact or close time win- dows, but overpredicts Precip on some days at San Sebastián-Igueldo while underpredicting at the remaining sites. In July, overpredictions or underpredictions occur during some hours/days at all sites except for Pris-14E and BrétignySur-Orge, where WRF at $0.5^{\circ}$ tends to underpredict. Largest deviations between the hourly predictions of Precip and 

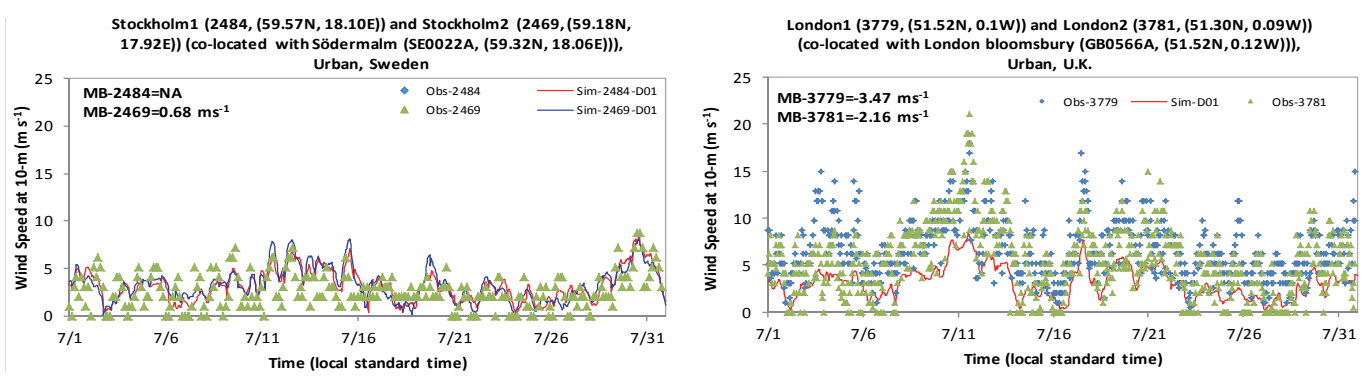

Düsseldorf1 (10400, (51.28N, 6.78E)) and Düsseldorf2 (EDDL, (51.28N 6.78E)) (co-located with Düsseldorf (000479,(51.30N, 6.77E) and
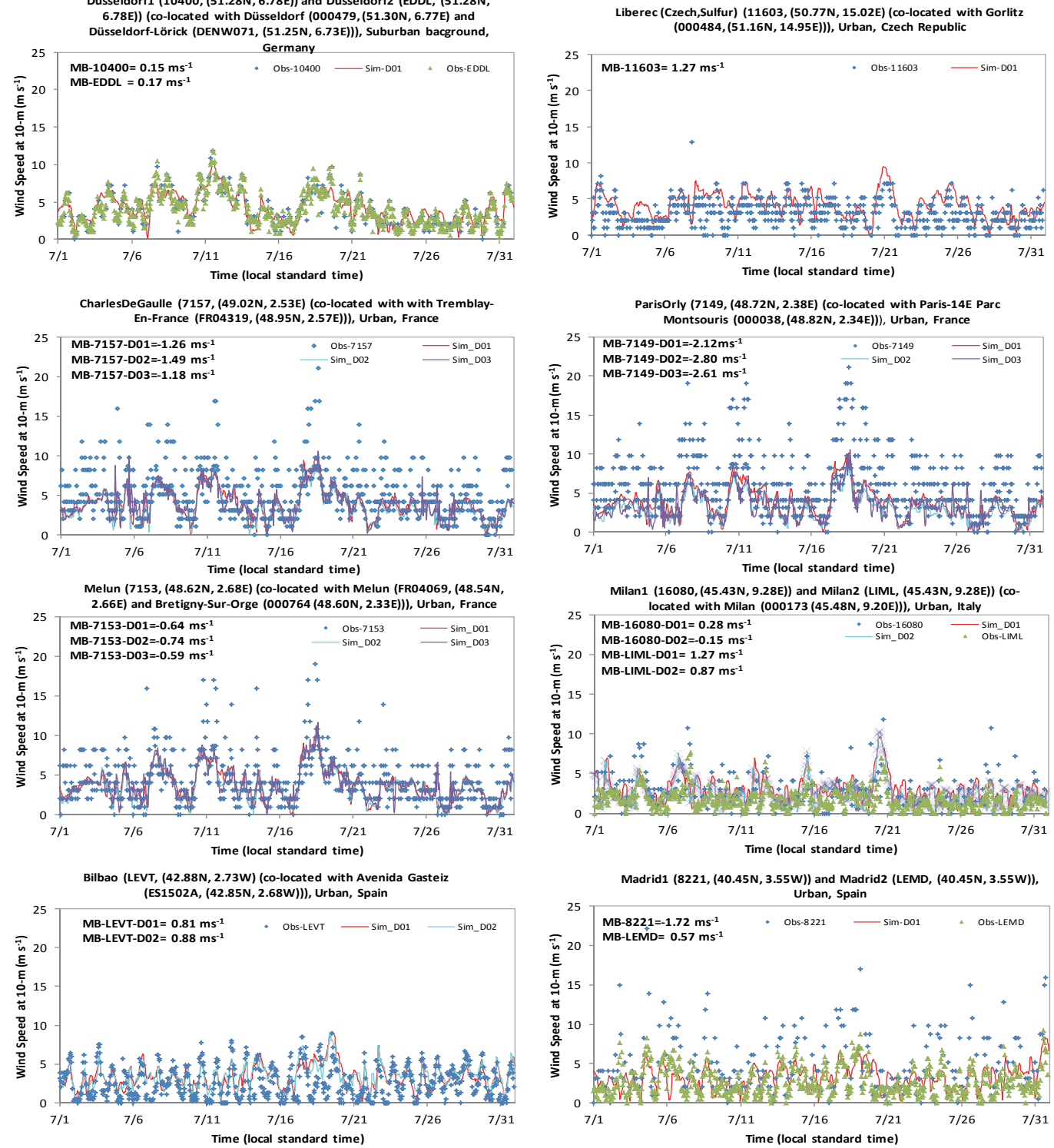

Fig. 13. Simulated and observed $10 \mathrm{~m}$ wind speed in July 2001 at selected sites. Statistics is not available (NA) at one site (Stockholm 1) where observations were not available.

observations occur at Stockholm, Düsseldorf 1, Görlitz, Milan, and San Sebastián-Igueldo. WRF gives either too intensive or too little Precip amounts and incorrect Precip time periods at those sites, indicating some limitations of the Grell-Devenyi ensemble cumulus parameterization and of the Purdue Lin cloud microphysics in capturing convective and non-convective clouds, respectively. In addition, a bug was reported in the Purdue Lin cloud microphysics that 

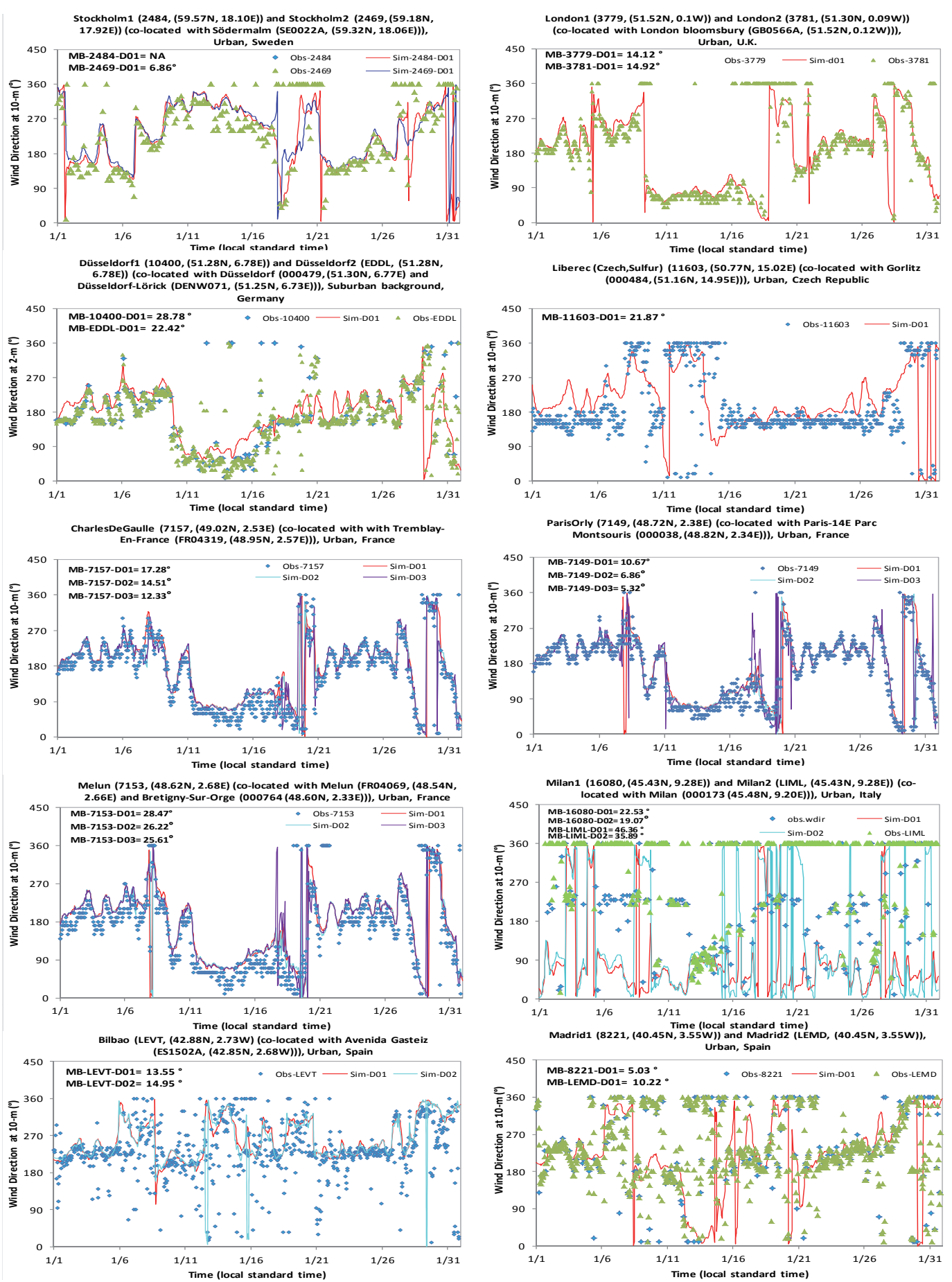

Fig. 14. Simulated and observed $10 \mathrm{~m}$ wind direction in January 2001 at selected sites. Statistics is not available (NA) at one site (Stockholm 1) where observations were not available.

caused the overprediction of cloud ice, graupel, as well as surface rainfall (http://www.mmm.ucar.edu/wrf/users/wrfv3/ known-prob.html) in WRF/Chem v3.0 and older. However, some uncertainties also exist in the Precip observations. For example, the very low or zero observed precipitation did not reflect the occurrence of thunderstorms recorded at Milan on some days in July (i.e., 3, 7-9, 27-29 July). 

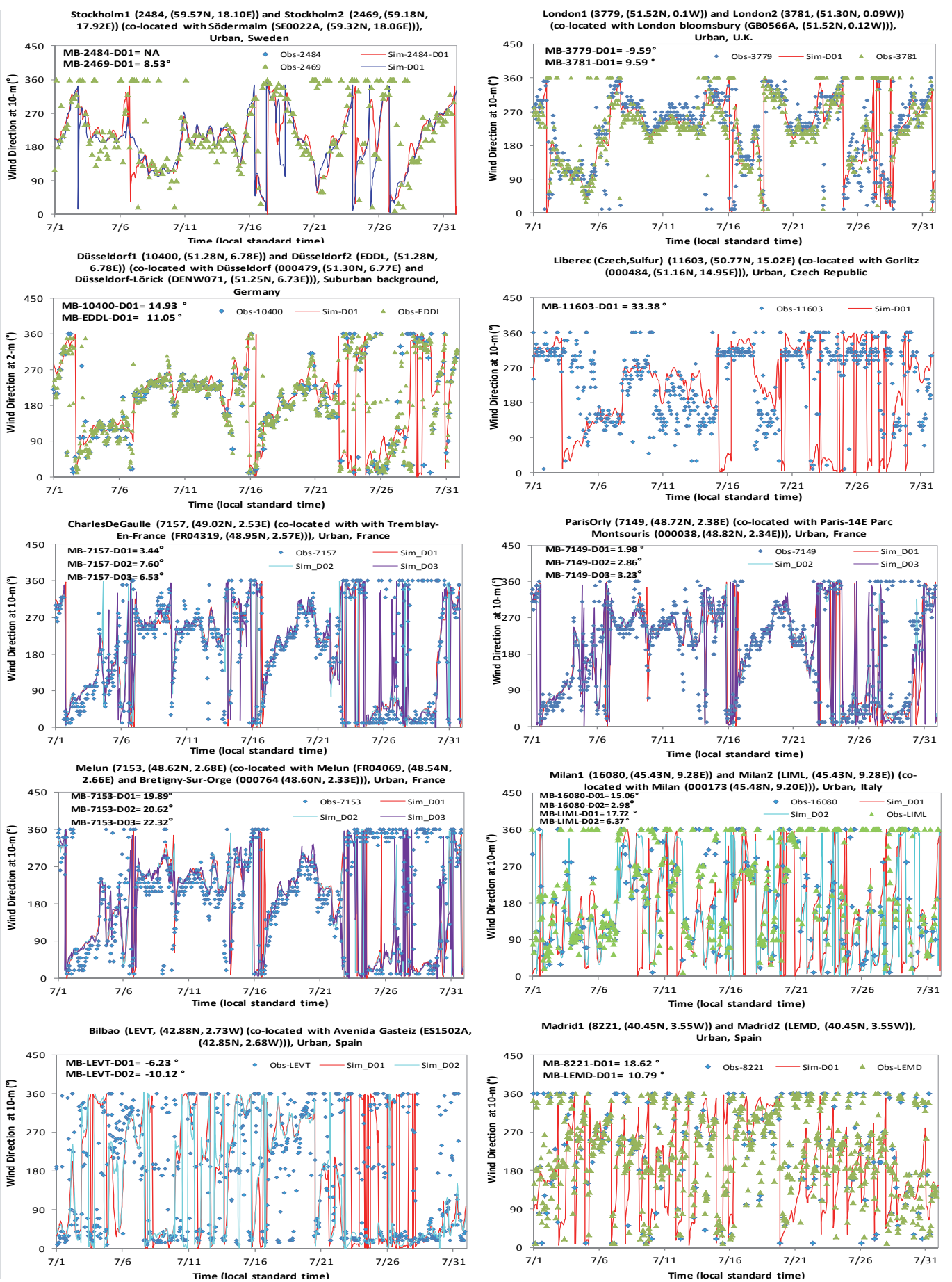

Fig. 15. Simulated and observed $10 \mathrm{~m}$ wind direction in July 2001 at selected sites. Statistics is not available (NA) at one site (Stockholm 1 ) where observations were not available.

\subsubsection{Sensitivity to horizontal grid resolution}

As shown in Figs. 8-9, at Charles de Gaulle, Paris Orly, and Melun, WRF predictions of T2 in January and July at grid resolutions of $0.125^{\circ}$ over D02 and $0.025^{\circ}$ over D03 are very similar; both give slightly higher maximum $\mathrm{T} 2$ and slightly lower minimum T2 on most days. WRF predictions at $0.125^{\circ}$ and $0.025^{\circ}$ in both months give slightly better maximum and minimum $\mathrm{T} 2$ against observations as compared with that at $0.5^{\circ}$ in January. At Milan 1/Milan 2, WRF at a grid resolution of $0.125^{\circ}$ gives slightly higher maximum $\mathrm{T} 2$ and slightly lower minimum T2 on most days in both January and July, 

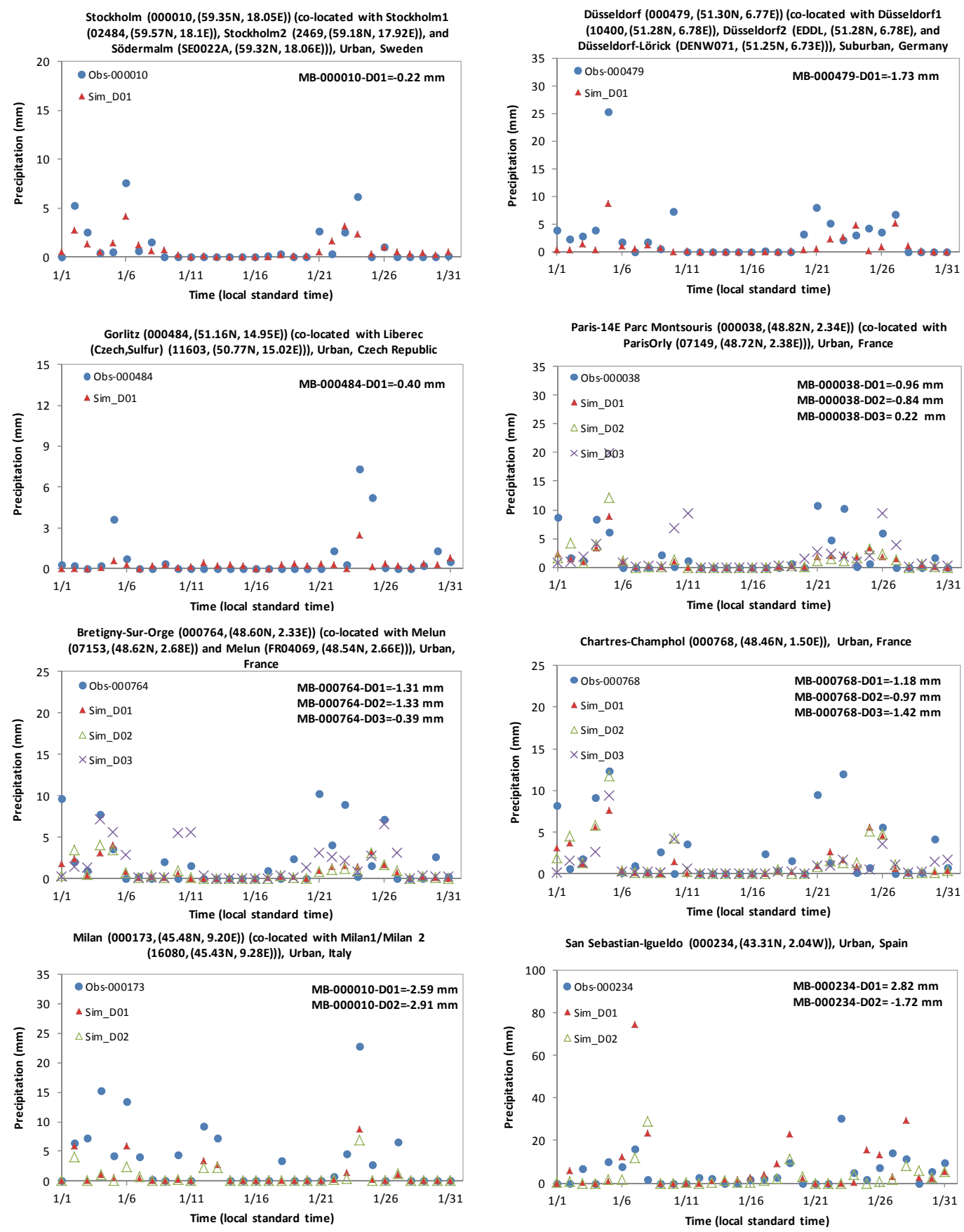

Fig. 16. Simulated and observed daily precipitation in January 2001 at selected sites.

but lower T2 throughout January and slightly higher maximum T2 and slightly lower minimum T2 in July at Bilbao. Compared to WRF at $0.5^{\circ}$, the use of $0.125^{\circ}$ slightly improves T2 performance at Milan 1 and Milan 2 in both months and significantly improves $\mathrm{T} 2$ performance at Bilbao (reducing MB from $1.84^{\circ} \mathrm{C}$ to $0.46^{\circ} \mathrm{C}$ ) in January, but deteriorates it at Bilbao (increasing MB from $-1.84^{\circ} \mathrm{C}$ to $-2.48{ }^{\circ} \mathrm{C}$ ) in July. Compared to WRF at $0.5^{\circ}$ and $0.125^{\circ}$, the use of $0.025^{\circ}$ slightly improves T2 performance at Paris
Charles de Gaulle in both months (e.g., reducing $\mathrm{MB}$ from $0.53^{\circ} \mathrm{C}$ at $0.5^{\circ}$ to $0.45^{\circ} \mathrm{C}$ at $0.025^{\circ}$ in January and from $-0.49^{\circ} \mathrm{C}$ at $0.5^{\circ}$ to $-0.35^{\circ} \mathrm{C}$ at $0.025^{\circ}$ in July) and Melun in July, largely improves T2 performance at Paris Orly in July (e.g., reducing $\mathrm{MB}$ from $-0.58^{\circ} \mathrm{C}$ at $0.5^{\circ}$ to $0.03{ }^{\circ} \mathrm{C}$ at $0.025^{\circ}$ ), but performs worse at Paris Orly and Melun in January. As shown in Figs. $10-11$, WRF at $0.125^{\circ}$ gives slightly higher Q2 at Milan 1/Milan 2 but lower Q2 at Bilbao in both January and July, showing better agreement with 
observations in terms of magnitude and MBs at Milan 1 in both months. At Paris Charles de Gaulle, Paris Orly, and Melun, WRF predictions in January and July at $0.125^{\circ}$ over D02 and at $0.025^{\circ}$ over D03 are overall very similar, having the best agreement with observations at $0.025^{\circ}$ in July (e.g., MBs are reduced from $0.51 \mathrm{~g} \mathrm{~kg}^{-1}$ to $-0.05 \mathrm{~g} \mathrm{~kg}^{-1}$ at Paris Orly in July) but slightly worse performance at $0.025^{\circ}$ in January. As shown in Figs. 12-13, in January, at Paris Charles de Gaulle and Paris Orly, WRF at $0.125^{\circ}$ and $0.025^{\circ}$ gives very similar predictions; both are lower than predicted WS10 at $0.5^{\circ}$. The differences in predicted WS10 at the three grid resolutions at Melun are smaller than those at Charles de Gaulle and Paris Orly, although the predicted WS10 values at $0.025^{\circ}$ remain the highest among the three simulations. Compared to observed WS10, WRF at the three grid resolutions captures well hourly variations of WS10, with better agreement at $0.025^{\circ}$ and $0.125^{\circ}$ than at $0.5^{\circ}$ at Paris Charles de Gaulle, Paris Orly, and Melun. WRF at $0.025^{\circ}$ gives the lowest MBs among all three simulations at Paris Orly and the second lowest MBs at the other two sites in January. Compared with WRF at $0.5^{\circ}, \mathrm{WRF}$ at $0.125^{\circ}$ gives slightly lower WS10 at Milan 1/Milan 2 but higher WS10 at Bilbao in January. It gives slightly better agreement with observations at Milan 1/Milan 2 but slightly worse agreement at Bilbao in January in terms of magnitudes and MBs. In July, at both Paris Charles de Gaulle and Melun, compared to observations of WS10, WRF at the three grid resolutions underpredicts WS10 significantly, with the lowest MBs at $0.025^{\circ}$. At Paris Orly, all three simulations significantly underpredicted WS10, although the results at $0.5^{\circ}$ are slightly better than those at finer grid resolutions. At Bilbao, WRF predictions at the two grid resolutions are very similar, replicating observed temporal variations but slightly underpredicting the magnitudes. At Milan 1/Milan 2, WRF at $0.125^{\circ}$ gives slightly better agreement with observed WS10 than at $0.5^{\circ}$ with lower MBs. As shown in Figs. 14-15, in January, WRF at $0.025^{\circ}$ gives the best agreement with the lowest MBs at Paris Charles de Gaulle, Paris Orly, and Melun. Compared to WRF at $0.5^{\circ}$, WRF at $0.125^{\circ}$ also reduces MB at Milan but slightly increases MB at Bilbao. In July, the use of $0.025^{\circ}$ deteriorates WD10 performance at Paris Charles de Gaulle, Paris Orly, and Melun. The use of $0.125^{\circ}$ helps reduce MB significantly at Milan 1 ; WRF at $0.5^{\circ}$ gives better agreement at Bilbao.

As shown in Figs. 16-17, at San Sebastián-Igueldo in January, while WRF at $0.5^{\circ}$ tends to overpredict Precip, WRF at $0.125^{\circ}$ reduces the wet bias (MB is reduced from $2.82 \mathrm{~mm}^{-1}$ to $-1.72 \mathrm{~mm}^{-1}$ ). At Milan, WRF at $0.5^{\circ}$ is in slightly closer agreement with observations than at $0.125^{\circ}$. At ChartresChamphol, WRF results at $0.5^{\circ}$ and $0.125^{\circ}$ are overall similar, both underpredicting precipitation in January. The use of a finer grid resolution of $0.025^{\circ}$ shows a worse performance at this site. At Pris-14E and Brétigny-sur-Orge, WRF at $0.025^{\circ}$ gives the best predictions, although it still overpredicts or underpredicts observed precipitation to some extent during rainy periods. In July, WRF at $0.125^{\circ}$ gives higher dry biases than WRF at $0.5^{\circ}$ at San Sebastián-Igueldo but changes dry bias at $0.5^{\circ}\left(\mathrm{MB}=0.45 \mathrm{~mm}^{-1}\right)$ to wet biases $\left(\mathrm{MB}=1.78 \mathrm{~mm}^{-1}\right)$ at Milan. WRF at $0.025^{\circ}$ gives the smallest wet bias at Pris-14E and Brétigny-sur-Orge but the worst overpredictions at Chartres-Champhol.

Figures 18-19 compare the simulated monthly mean vertical profiles of $T, \mathrm{~T}_{\mathrm{d}}$, WS, and WD at a horizontal grid resolution of $0.5^{\circ}$ with the sounding observations at eight sites. WRF at all grid resolutions (figures not shown at $0.125^{\circ}$ and $0.025^{\circ}$ ) reproduces very well vertical profiles of $T$ at all sites in both months, although it fails to reproduce observed surface temperature inversions at Düsseldorf and Paris in January. It also captures well the vertical profiles of $T_{d}$ below $300 \mathrm{mb}$ at most sites in both months. Larger deviations occur in vertical profiles of $T_{d}$ above $300 \mathrm{mb}$, with higher $T_{d}$ from the model, indicating the model's inability to capture moisture aloft. Among the eight sites, the model shows difficulties in capturing vertical profiles of $T_{d}$ at the London and Madrid sites with larger deviations from observations than those at other sites in both months. Differently from WS10 predictions, which are overpredicted at most sites in January, the observed WSs aloft are underpredicted at all sites in January. Underpredictions of WS aloft also occur at all sites in July. WRF, however, is able to simulate higher WS at altitudes where the observed WS are also high in both months. The observed WDs at various altitudes are reproduced reasonably well with $10-20^{\circ}$ deviations at most sites in both months. Relatively large deviations from WS and WD observations aloft occur at Stockholm and Liberec in both months.

\section{Conclusions}

This paper describes two 3-D air quality model systems (WRF/Polyphemus and WRF/Chem-MADRID) to be evaluated for their capability to simulate pollutant concentrations over Europe in Part 2, the simulation design, as well as the evaluation datasets and protocols. Both models use WRF to generate meteorological fields for chemical predictions. In this Part 1 , we described the application of WRF for January and July 2001 over triple-nested domains in Western and Central Europe at three horizontal grid resolutions: $0.5^{\circ}$ over a large area in Western Europe; $0.125^{\circ}$ over an area covering France, Germany, the Netherlands, Belgium, Switzerland, Luxembourg, Slovenia, most of Austria, and parts of the UK, Italy, the Czech Republic, Spain, Croatia, and Poland; and $0.025^{\circ}$ over an area covering the greater Paris region in France.

WRF predictions were evaluated using available observational databases. The WRF simulation at a horizontal grid resolution of $0.5^{\circ}$ overpredicts downward shortwave radiation and outgoing longwave radiation fluxes in both months, and downward longwave radiation fluxes in July, due to the limitations of the Goddard shortwave radiation scheme 

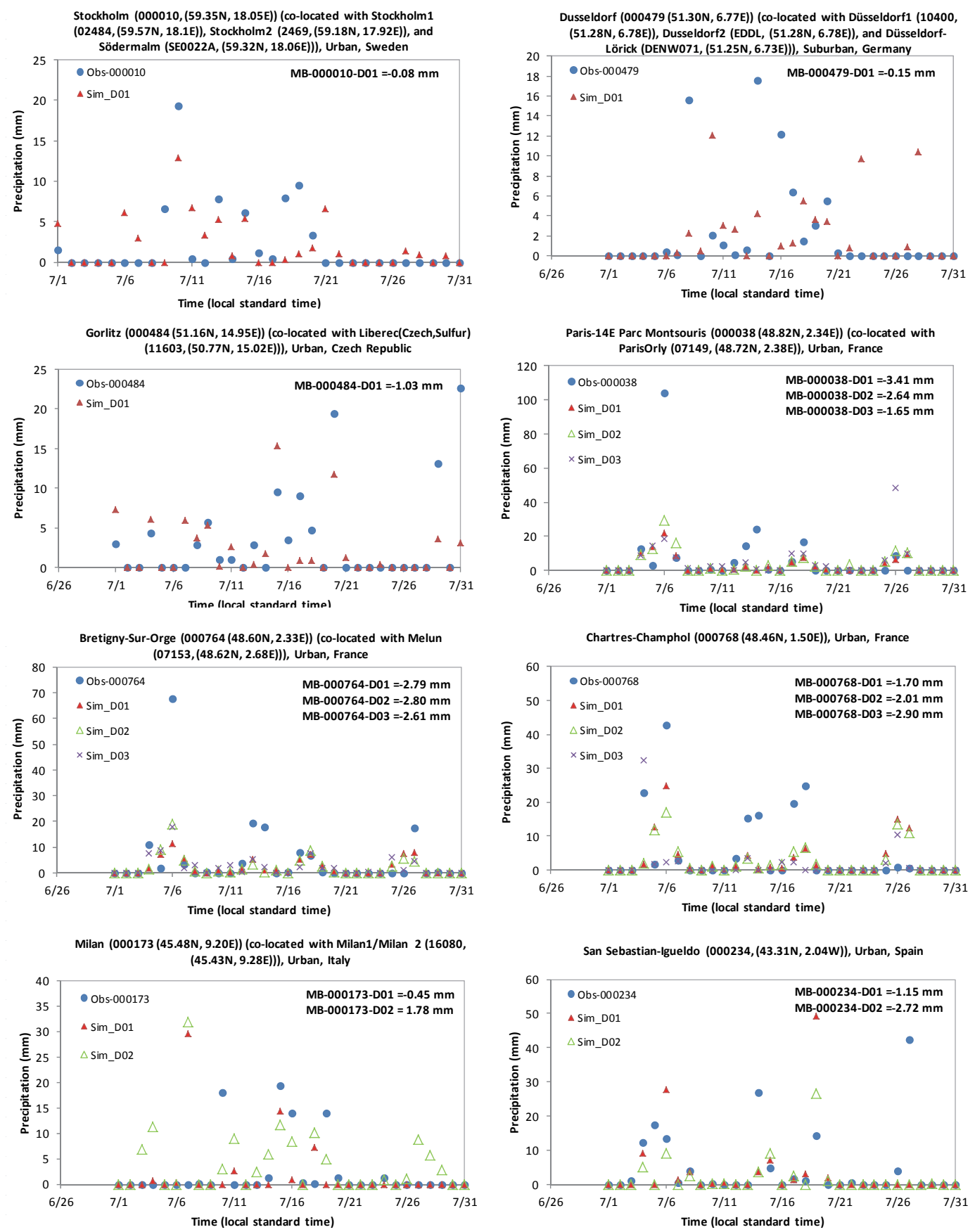

Fig. 17. Simulated and observed daily precipitation in July 2001 at selected site.

in both months and the neglect of the effect of cumulus clouds on radiation and the contribution of convective clouds to cloud water content in July. WRF reproduces the observed spatial gradients of temperatures and specific humidity with the coldest/driest values in the northwest and the hottest/wettest in the south in both January and July. In January, although the positive bias (an $\mathrm{MB}$ of $0.5^{\circ} \mathrm{C}$ and an NMB of $19.2 \%$ ) in $\mathrm{T} 2$ dominates, the largest cold biases $\left(-5\right.$ to $\left.-2{ }^{\circ} \mathrm{C}\right)$ occur in the Alps area and the eastern por- tion of the domain, likely due to several limitations in model initialization and treatments (e.g., too cold soil temperature, too much soil moisture, too many daytime clouds, and a poor treatment of snow-related processes). The compensation of the dry and wet biases results in a good agreement in Q2 (an MB of $0.1 \mathrm{~g} \mathrm{~kg}^{-1}$ and an NMB of $3.0 \%$ ). Large overpredictions (an MB of $2.1 \mathrm{~m} \mathrm{~s}^{-1}$ and an NMB of $59.2 \%$ ) occur in WS10 with the worst ones $\left(>1.6 \mathrm{~m} \mathrm{~s}^{-1}\right)$ over low-lying coastal areas and the Alps and the Carpathian Mountains, 


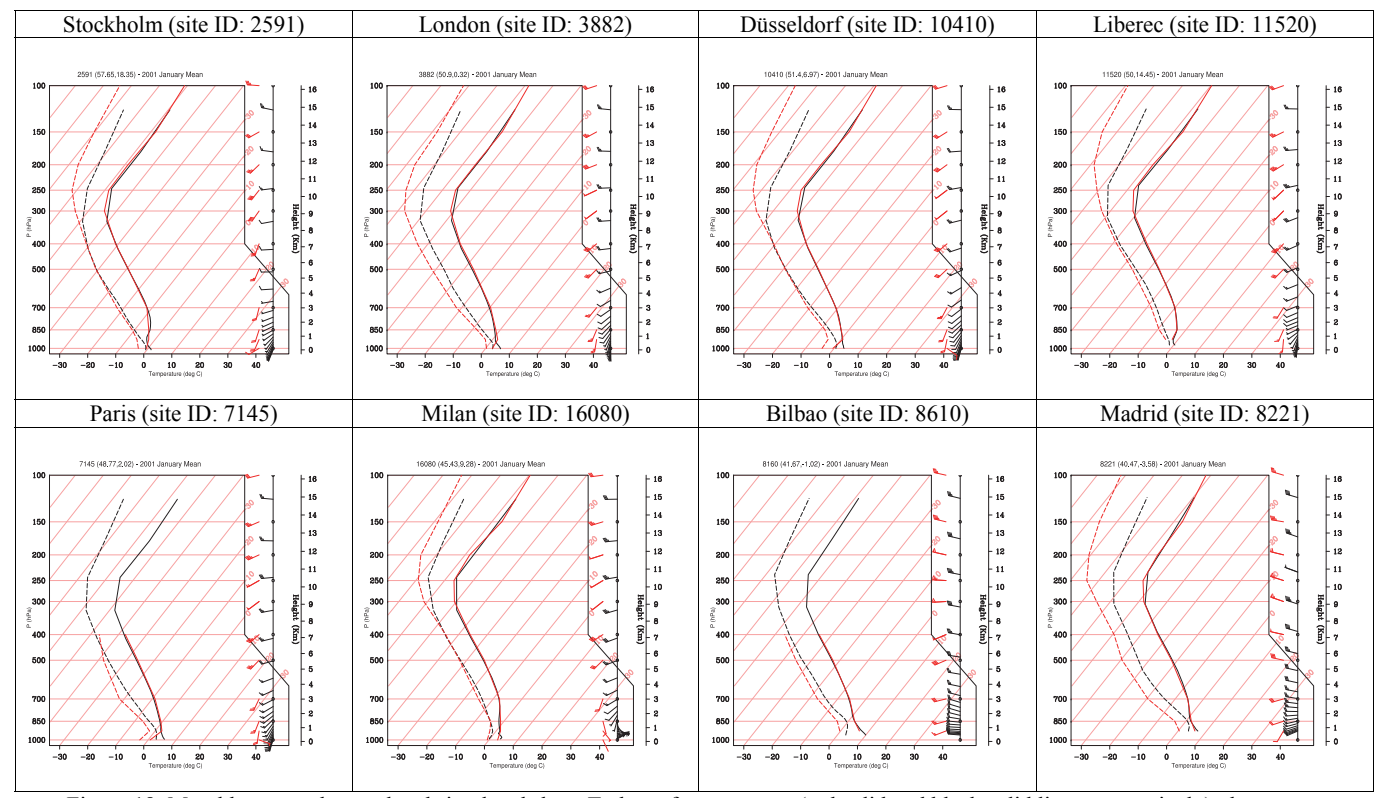

Fig. 18. Monthly mean observed and simulated skew-T plots of temperature (red solid and black solid lines, respectively), dew point temperature (red dash and black dash lines, respectively), and wind speed and direction (red and black staffs and attached barbs, respectively, with a triangle, a long barb, and a short barb perpendicular to the overall staff representing 50, 10, and 5 knots, respectively) at eight stations over D01 in January 2001.

due mainly to a poor representation of surface drag exerted by the unresolved topography (mountains, hills and valleys) and other smaller scale terrain features in WRF. In contrast to the relatively poorer performance in January, WRF performs well in July, with slight underpredictions in T2, Q2, RH2, and WS10 and a small MB in WD10. These results indicate the model's difficulty in simulating winter temperatures at many sites and summer temperature at some sites due to model's limitations in representing shortwave radiation, cloud formation, land surface heat fluxes, as well as wind patterns and mesoscale circulation systems over mountain/hill and high altitude regions. Precip is underpredicted at many sites with a domainwide NMB of $-54.8 \%$, particularly in the Alps and coastal areas in Norway and Estonia, making an accurate prediction at this grid resolution very challenging. Different from January, Precip in July is slightly overpredicted at most sites with an NMB of $9.9 \%$, particularly over San Marino, Slovenia, and eastern Belarus. The underprediction in winter is likely due to underpredictions in ice clouds because of a lack of ice nucleation treatments in WRF. The overprediction in July may be due to too frequent afternoon convective rainfall and/or an overestimation in the intensity of the rainfall predicted by the cumulus parameterization and a bug in the cloud microphysics module. For site-specific temporal variations, in January, WRF over D01 captures well T2 in terms of both magnitudes and diurnal variations at many sites but significantly underpredicts $\mathrm{T} 2$ at mountain/high altitude and large urban center sites and during snow events, due to some limitations of the representations of snow melting treatment, surface energy balance, and urban heat island and $\mathrm{CO}_{2}$ dome effects in WRF. Larger discrepancies between simulated and observed Q2 also exist at mountain/high altitude and large urban center sites and during snow events in January. WRF captures well WS10 in terms of hourly variations at all sites but overpredicts the magnitudes of WS10 at some sites with complex topography and under light wind conditions. WRF generally produces WD10 observations and diurnal variation at most sites in both months, but large deviations occur at a few sites during some hours, leading to poor overall performance. WRF is able to capture precipitation events at all sites with exact or close time windows, but underpredicts precipitation in terms of amount and lengths, due to some limitations in the Purdue Lin cloud microphysics module. In July, WRF performs much better at all sites and captures very well the strong diurnal variations of T2, despite a similar difficulty (but to a lesser extent) in capturing observed T2 at mountain sites. The underpredictions in nighttime temperatures at urban sites are attributed to an unrealistic representation of urban canopy and urban heat island in the default treatments in WRF. WRF gives relatively large underpredictions in Q2 at urban sites where thunderstorms often occur, illustrating the model's difficulty in simulating water balance under humid subtropical summer climate conditions. WRF reproduces well diurnal variations and magnitudes of WS10, but significantly underpredicts WS10 at large urban center sites. However, it also gives larger deviations in WD10 in July than in January due in part to the model's limitation in capturing the wind fields as well as heat balance over a 


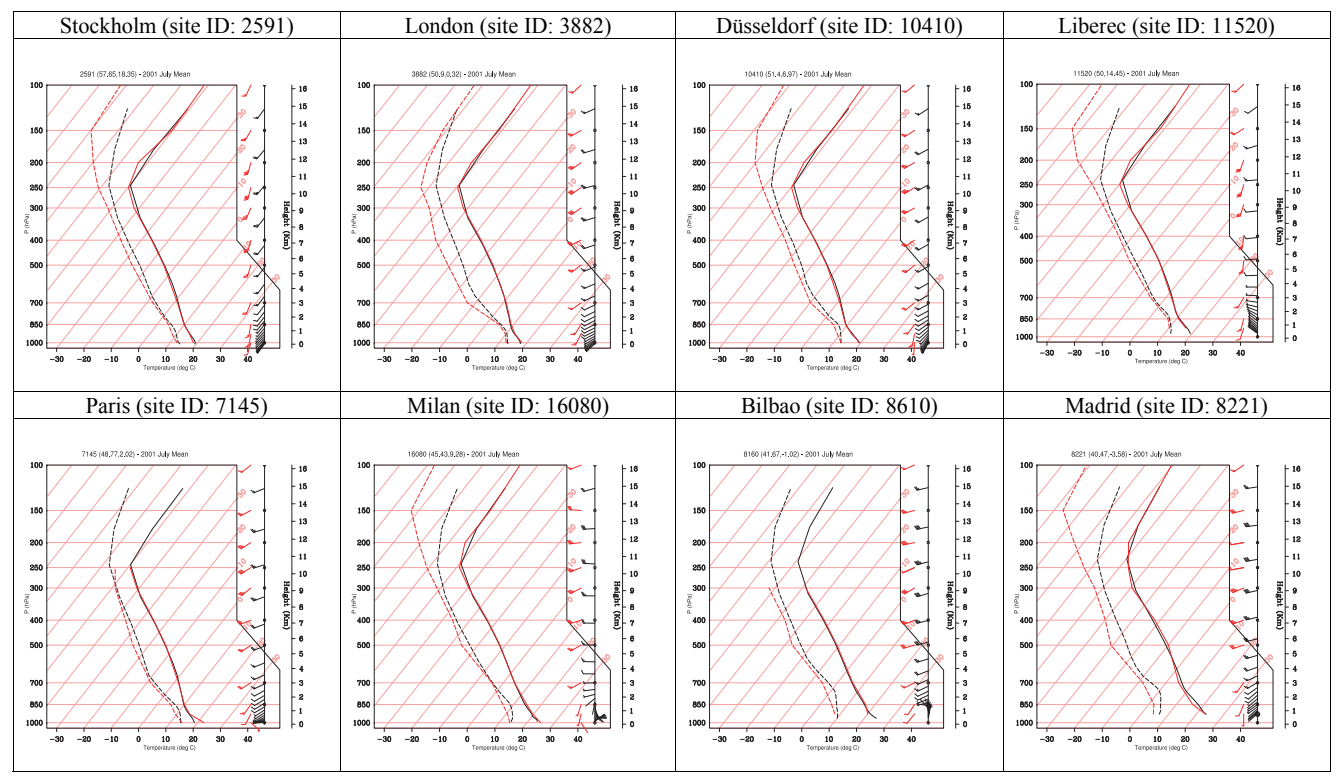

Fig. 19. Monthly mean observed and simulated skew-T plots of temperature (red solid and black solid lines, respectively), dew point temperature (red dash and black dash lines, respectively), and wind speed and direction (red and black staffs and attached barbs, respectively, with a triangle, a long barb, and a short barb perpendicular to the overall staff representing 50, 10, and 5 knots, respectively) at eight stations over D01 in July 2001.

complex terrain and the influences of urban heat islands and $\mathrm{CO}_{2}$ domes. Underpredictions of precipitation occur at most of the selected sites. WRF reproduces well vertical profiles of $T$ and $\mathrm{WD}$ at all sites and $\mathrm{T}_{\mathrm{d}}$ below $300 \mathrm{mb}$ at most sites in both months, although it tends to overpredict $T_{d}$ above $300 \mathrm{mb}$ and underpredict WS aloft at all sites in both months.

The sensitivity of model predictions to horizontal grid resolutions is examined. In January over D02, the performance of WRF at $0.125^{\circ}$ slightly to moderately improves for OLR, Q2, WS10, and WD10 in terms of correlation coefficient, MB, MGE, RMSE, NMB, and NME and Precip in terms of MB, RMSE, NMB, and IOA,, demonstrating the benefits using a fine grid resolution. It slightly deteriorates for SWDOWN, LWDOWN, T2 and RH2 in terms of NMB, but with reduced RMSE and NME for T2 and RH2. In July over D02, the use of a grid resolution of $0.125^{\circ}$ slightly improves the model performance for all these variables except for SWDOWN, OLR, WS10, and Precip. When the grid resolution further increases from $0.125^{\circ}$ to $0.025^{\circ}$, the model performance for all these variables is not always the best. The best model performance in terms of NMB is obtained for T2, WD10, and Precip at $0.025^{\circ}$, for WS10 at $0.125^{\circ}$, and for Q2 and $\mathrm{RH} 2$ at $0.5^{\circ}$ over D03 in January. The best model performance in terms of NMB is obtained for T2, RH2, and Precip at $0.025^{\circ}$, for Q2 at $0.125^{\circ}$, and for WS10 and WD10 at $0.5^{\circ}$ over D03 in July. Temporal variations of T2, Q2, and WD10 are relatively insensitive, but those of WS10 and Precip are moderately to highly sensitive to horizontal grid resolutions at most sites. The predictions of T2, Q2, RH2, WS10, and WD10 at $0.125^{\circ}$ and $0.025^{\circ}$ are very similar; both show differences with predictions at $0.5^{\circ}$. Compared with results at $0.5^{\circ}$, WRF at $0.125^{\circ}$ and $0.025^{\circ}$ in both months gives slightly better T2, WS10, and WD10 at most sites in January, slightly better Q2 at all sites in July, and moderate to significant improvement in precipitation at most sites in January and July.

While the above results show reasonably good performance that is consistent with other mesoscale meteorological model applications, they also indicate a need to further improve model representations of mesoscale processes and phenomena such as shortwave radiation, snow-related processes, subgrid-scale surface roughness elements, urban canopy treatments, cloud microphysics, convective cloud processes, and ice nucleation treatments at small scales. These biases in model meteorological predictions may affect the accuracies in the chemical predictions of WRF/Chem-MADRID and WRF/Polyphemus, which is presented in Part 2.

Acknowledgements. This project is sponsored by the EPA STAR \#R83337601, the NSF/USDA EaSM program AGS-1049200, and the fellowship award \#704389J, the Atmospheric Environment Center (CEREA)/École des Ponts ParisTech, France, through a visiting professorship of Y. Zhang at CEREA, the Joint Laboratory of École des Ponts ParisTech and EDF R\&D, Paris, France, and COST ES1004. Thanks are due to contributions of former and current members of the air quality forecasting laboratory at NCSU, including Wei Wang, Shuai Zhu, Xu-Yan Liu, Changjie Cai, Xin Zhang, and Kai Wang, who obtained dataset information, processed data, and made plots. 
Edited by: F. Yu

\section{References}

Abdul-Razzak, H. and Ghan, S. J.: A parameterization of aerosol activation. 3. Sectional representation, J. Geophys. Res., 107, D3, 4026, doi:10.1029/2001JD000483, 2002.

Aphekom (Improving Knowledge and Communication for Decision Making on Air Pollution and Health in Europe): Summary report of the Aphekom project, 2008-2011, Institute De Veille Sanitaire, 94415, Saint-Maurice Cedex, France, 2011.

Baklanov, A., Hänninen, O., Slørdal, L. H., Kukkonen, J., Bjergene, N., Fay, B., Finardi, S., Hoe, S. C., Jantunen, M., Karppinen, A., Rasmussen, A., Skouloudis, A., Sokhi, R. S., Sørensen, J. H., and Ødegaard, V.: Integrated systems for forecasting urban meteorology, air pollution and population exposure, Atmos. Chem. Phys., 7, 855-874, doi:10.5194/acp-7-855-2007, 2007.

Baklanov, A., Korsholm, U., Mahura, A., Petersen, C., and Gross, A.: ENVIRO-HIRLAM: on-line coupled modelling of urban meteorology and air pollution, Adv. Sci. Res., 2, 41-46, doi:10.5194/asr-2-41-2008, 2008.

Baklanov, A.: Chemical weather forecasting: a new concept of integrated modelling, Adv. Sci. Res., 4, 23-27, doi:10.5194/asr-423-2010, 2010.

Baklanov, A., Mahura, A., and Sokhi, R. (Eds.): Integrated Systems of Meso-Meteorological and Chemical Transport Models, 1st edn., 242 pp., Springer, ISBN 978-3-642-13979-6, 2011.

Brunekreef, B., and Forsberg, B.: Epidemiological evidence of effects of coarse airborne particles on health, Eur. Respir. J., 26, 309-318, 2005.

Chapman, E. G., Gustafson Jr., W. I., Easter, R. C., Barnard, J. C., Ghan, S. J., Pekour, M. S., and Fast, J. D.: Coupling aerosolcloud-radiative processes in the WRF-Chem model: Investigating the radiative impact of elevated point sources, Atmos. Chem. Phys., 9, 945-964, doi:10.5194/acp-9-945-2009, 2009.

Chen, F., and Dudhia, J.: Coupling an Advanced Land SurfaceHydrology Model with the Penn State-NCAR MM5 Modeling System. Part I: Model Implementation and Sensitivity, Mon. Weather Rev., 129, 569-585, 2001.

Chen, S. H., and Sun, W. Y.: A one-dimensional time dependent cloud model, J. Meteorol. Soc. Jpn., 80, 99-118, 2002.

Chen, F., Kusaka, H., Tewari, M., Bao, J-W., Hirakuchi, H.: Utilizing the coupled WRF/LSM/urban modeling system with detailed urban classification to simulate the urban heat island phenomenon over the greater Houston area, Paper presented at the American Meteorological Society Fifth Symposium on the Urban Environment, Vancouver, British Columbia, 23-27, 2004.

Chin, M., Rood, R., Lin, S.-J., Müller, J., and Thompson, A.: Atmospheric sulfur cycle in the global model GOCART: model description and global properties, J. Geophys. Res., 105, 2467124687, 2000.

Chou, M. D., Suarez, M. J., Ho, C. H., Yan, M. M. H., and Lee, K. T.: Parameterizations for cloud overlapping and shortwave single-scattering properties for use in general circulation and cloud ensemble models, J. Clim., 11, 202-214, 1998.

Chuang, M.-T., Zhang, Y. and Kang, D.-W.: Application of WRF/Chem-MADRID for Real-Time Air Quality Forecasting over the Southeastern United States, Atmos. Environ., 45, 6241$6250,2011$.
Debry, E., Fahey, K., Sartelet, K., Sportisse, B., and Tombette, M.: Technical Note: A new SIze REsolved Aerosol Model (SIREAM), Atmos. Chem. Phys., 7, 1537-1547, www. atmos-chem-phys.net/7/1537/2007/, 2007.

Easter, R. C., Ghan, S. J., Zhang, Y., Saylor, R. D., Chapman, E. G., Laulainen, N. S., Abdul-Razzak, H., Leung, L. R., Bian, X., and Zaveri, R. A.: MIRAGE: Model description and evaluation of aerosols and trace gases, J. Geophys. Res., 109, D20210, doi:10.1029/2004JD004571, 2004.

Ek, M. B., Mitchell, K. B., Lin, Y., Rogers, B., Grunmann, P., Koren, V., Gayno, G., Tarpley, J. D.: Implementation of NOAH land surface model advances in the National Centers for Environmental Prediction operational mesoscale Eta model, J. Geophys. Res., 108, 8851, doi:10.1029/2002JD003296, 2003.

EMEP: Transboundary particulate matter in Europe: Status report 4/2006, 140 pp., 2006a.

EMEP: Transboundary acidification, eutrophication and ground level ozone in Europe since 1990 to 2004. EMEP Status Report 1/2006 to Support the Review of Gothenburg Protocol, Appendixes, 80 pp., $2006 \mathrm{~b}$.

Emery, C., Tai, E., and Yarwood, G.: Enhanced meteorological modeling and performance evaluation for two texas episodes, Report to the Texas Natural Resources Conservation Commission, ENVIRON International Corporation, Novato, CA, August 31, 2001.

Escudero, M., Querol, X., Avila, A. and Cuevas, E.: Origin of the exceedances of the European daily PM limit value in regional background areas of Spain, Atmos. Environ., 41, 730-744, 2007.

Fahey, K., and Pandis, S.: Optimizing model performance: variable size resolution in cloud chemistry modeling, Atmos. Environ., 35, 4471-4478, 2001.

Fast, J. D., Gustafson Jr., W. I., Easter, R. C., Zaveri, R. A., Barnard, J. C., Chapman, E. G., Grell, G. A., and Peckham, S. E.: Evolution of ozone, particulates, and aerosol direct radiative forcing on the vicinity of Houston using a fully coupled meteorology-chemistry-aerosol model, J. Geophys. Res., 111, D21305, doi:10.1029/2005JD006721, 2006.

Forkel R, Werhahn J., Hansen A.B., McKeen S., Peckham S., Grell G., Suppan P.: Effect of aerosol-radiation feedback on regional air quality - A case study with WRF/Chem, Atmos. Environ., 53, 202-211, 2012.

Galmarini, S., Steyn, D.G., Schere, K., and Moran, M.: Advancing the evaluation of regional-scale air quality models, EUR24245, ISBN 978-92-79-15007-4, 2010.

Giannouli, M., Kalognomou, E.-A., Mellios, G., Moussiopoulos, N., Samaras, Z., and Fiala, J.: Impact of European emission control strategies on urban and local air quality, Atmos. Environ., 45, 4753-4762, 2011.

Gilliam, G., Pleim, J., and Xiu, A.: Implementation of the PleimXiu Land Surface Model and Asymmetric Convective Model in the WRF Model, presentation at the 8th Annual WRF User's Workshop, Boulder, CO, 11-15 June, 2007.

Gong, S., Barrie, L. A., and Blanchet, J. P.: Modeling sea salt aerosols in the atmosphere. 1: Model development, J. Geophys. Res., 102, 3805-3818, 1997.

Grell, G. A., and Devenyi, D.: A generalized approach to parameterizing convection combining ensemble and data assimilation techniques, Geophys. Res. Lett., 29, 1693, doi:10.1029/2002GL015311, 2002. 
Grell, G. A., Knoche, R., Peckham, S. E., and McKeen, S. A.: Online versus offline air quality modeling on cloud-resolving scales, Geophys. Res. Lett., 31, L16117, doi:10.1029/2004GL020175, 2004.

Grell, G. A., Peckham, S. E., Schmitz, R., McKeen, S. A., Frost, G., Skamarock, W. C., and Eder, B.: Fully coupled "online" chemistry within the WRF model, Atmos. Environ., 39, 6957-6975, 2005.

Guenther A., Zimmerman, P., Harley, P., Monson, R., and Fall, R.: Isoprene and monoterpene emission rate variability: model evaluation and sensitivity analysis, J. Geophys. Res, 98, 12609$12617,1993$.

Guenther, A., Baugh, B., Brasseur, G., Greenberg, J., Harley, P., Klinger, L., Serca, D., and Vierling, L.: Isoprene emission estimates and uncertainties for the Central African EXPRESSO study domain, J. Geophys. Res.-Atmos., 104, 30 625-30 639, 1999.

Guenther, A., Karl, T., Harley, P., Wiedinmyer, C., Palmer, P. I., and Geron, C.: Estimates of global terrestrial isoprene emissions using MEGAN (Model of Emissions of Gases and Aerosols from Nature), Atmos. Chem. Phys., 6, 3181-3210, doi:10.5194/acp-63181-2006, 2006.

Hong, S., Noh, Y., and Dudhia, J.: A new vertical diffusion package with an explicit treatment of entrainment processes, Mon. Weather Rev., 134, 2318-2341, 2006.

Jacob, D. J.: Heterogeneous chemistry and tropospheric ozone, Atmos. Environ., 34, 2131-2159, 2000.

Jacobson, M. Z.: Development and application of a new air pollution modeling system, Part II: Aerosol module structure and design, Atmos. Environ., 31A, 131-144, 1997.

Jacobson, M. Z.: GATOR-GCMM: A global- through urban-scale air pollution and weather forecast model 1 . Model design and treatment of subgrid soil, vegetation, roads, rooftops, water, sea, ice, and snow, J. Geophys. Res., 106, 5385-5401, 2001.

Jacobson, M. Z.: The enhancement of local air pollution by urban $\mathrm{CO}_{2}$ domes, Environ. Sci. Technol., 44, 2497-2502, doi:10.1021/es903018m, 2010.

Jacobson, M. Z., Tabazadeh, A., and Turco, R. P.: Simulating equilibrium within aerosols and non-equilibrium between gases and aerosols, J. Geophys. Res., 101, 9079-9091, 1996.

Janjic, Z. I.: Nonsingular Implementation of the Mellor-Yamada Level 2.5 Scheme in the NCEP Meso model, NCEP Office Note, 437, 61 pp., 2002.

Jiang, F., Liu, Q., Huang, X.-X., Wang, T.-J., Zhuang, B.-L., and Xie, M.: Regional modeling of secondary organic aerosol over China using WRF/Chem, J. Aerosol Sci., 43, 57-73, 2012.

Jiménez, P. A. and Dudhia, J.: Improving the representation of resolved and unresolved topographic effects on surface wind in the WRF model, the $12^{\text {th }}$ WRF Users' Workshop, 21-25 June, Boulder, CO, 2011.

Jiménez-Guerrero, P., Pérez, C., Jorba, O., and Baldasano, J. M.: Contribution of Saharan dust in an integrated air quality system and its on-line assessment, Geophys. Res. Lett., 35, L03814, doi:10.1029/2007GL031580, 2008.

Kallos, G., Astitha, M., Katsafados, P., and Spyrou, C.:, LongRange Transport of Anthropogenically and Naturally Produced Particulate Matter in the Mediterranean and North Atlantic: Current State of Knowledge, J. Appl. Meteorol. Climatol., 46, 1230$1251,2007$.
Kallos, G., Spyrou, C., Astitha, M., Mitsakou, C., Solomos, S., Kushta, J., Pytharoulis, I., Katsafados, P., Mavromatidis, E., and Papantoniou, N.: Ten-year operational dust forecasting - Recent model development and future plans, IOP Conf. Ser.: Earth Environ. Sci., 7, 012012, doi:10.1088/1755-1307/7/1/012012, 2009.

Kim, Y., Couvidat, F., Sartelet, K., and Seigneur, C.: Comparison of different gas-phase mechanisms and aerosol modules for simulating particulate matter formation, J. Air Waste Manage. Assoc, 61, 1218-1226, 2011.

Kim, Y., Sartelet, K., Raut, J. C., and Chazette, P.: Evaluation of the WRF/urban model over Greater Paris, Boundary-layer meteorology, in press, 2013.

Klein Tank, A. M. G., Wijngaard, J. B., Können, G. P., Böhm, R., Demarée, G., Gocheva, A., Mileta, M., Pashiardis, S., Hejkrlik, L., Kern-Hansen, C., Heino, R., Bessemoulin, P., MüllerWestermeier, G., Tzanakou, M., Szalai, S., Pálsdóttir, T., Fitzgerald, D., Rubin, S., Capaldo, M., Maugeri, M., Leitass, A., Bukantis, A., Aberfeld, R., van Engelen, A. F. V., Forland, E., Mietus, M., Coelho, F., Mares, C., Razuvaev, V., Nieplova, E., Cegnar, T., Antonio López, J., Dahlström, B., Moberg, A., Kirchhofer, W., Ceylan, A., Pachaliuk, O., Alexander, L. V., and Petrovic, P.: Daily dataset of 20th-century surface air temperature and precipitation series for the European Climate Assessment, Int. J. Climatol., 22, 1441-1453, 2002.

Koike, M., Kondo, Y., Takegawa, N., Kita,K., Miyazaki, Y., Hu, M., Chang, S.-Y., Blake, D. R., Fast, J. D., Zaveri, R. A., Streets, D. G., Zhang, Q. and Zhu, T.: Spatial and temporal variations of aerosols around Beijing in summer 2006: Model evaluation and source apportionment, J. Geophys. Res., 114, D00G13, doi:10.1029/2008JD010906, 2009.

Kusaka, H., Chen, F., Tewari, M., Dudhia, J., D. O. Gill, M. G. Duda, Wang, W.: Numerical Simulation of Urban Heat Island Effect by the WRF Model with $4 \mathrm{~km}$ Grid Increment: An Inter-Comparison Study between the Urban Canopy Model and Slab Model, J. Meteorol. Soc. Jpn., 90B, 33-45, doi:10.2151/jmsj.2012-B03, 2012.

Liebmann, B. and Smith, C. A.: Description of a Complete (Interpolated) Outgoing Longwave Radiation Dataset, B. Am. Meteorol. Soc., 77, 1275-1277, 1996.

Lin, Y.-L., Farley, R. D., and Orville, H. D.: Bulk parameterization of the snow field in a cloud model, J. Clim. Appl. Meteorol., 22, 1065-1092, 1983.

Liu, X.-H. and Zhang, Y.: Understanding of the Formation Mechanisms of Ozone and Particulate Matter at a fine scale over the Southeastern US: Process Analyses and Responses to FutureYear Emissions, Atmos. Environ., 74, 259-276, 2013.

Mallet, V. and Sportisse, B.: Uncertainty in a chemistry-transport model due to physical parameterizations and numerical approximations: An ensemble approach applied to ozone modeling, J. Geophys. Res., 111, D01302, doi:10.1029/2005JD006149, 2006.

Mass, C., Ovens, D., Westrick, K., and Colle, B. A.: Does increasing horizontal resolution produce more skillful forecasts?, BAMS, 407-430, March, 2002.

Mass, C. and Ovens, D.: WRF model physics: progress, problems, and perhaps some solutions, the 11th WRF Users' Workshop, 21-25 June, Boulder, CO, 2010.

Mass, C. and Ovens, D.: Fixing WRF's High Speed Wind Bias: A New Subgrid Scale Drag Parameterization and the Role of Detailed Verification, paper 2011.9B.6, the 91st AMS Annual 
Meeting, Jan 23-27, in Seattle, WA, 2011.

Matsui, H., Koike, M., Kondo, Y., Takegawa, N., Kita,K., Miyazaki, Y., Hu, M., Chang, S.-Y., Blake, D. R., Fast, J. D., Zaveri, R. A., Streets, D. G., Zhang, Q. and Zhu, T.: Spatial and temporal variations of aerosols around Beijing in summer 2006: Model evaluation and source apportionment, J. Geophys. Res., 114, D00G13, doi:10.1029/2008JD010906, 2009.

McMurry, P. H. and Friedlander, S. K.: New particle formation in the presence of an aerosol, Atmos. Environ., 13, 1635-1651, 1979.

Meister, K., Johansson, C., and Forsberg, B.: Estimated Short-Term Effects of Coarse Particles on Daily Mortality in Stockholm, Sweden, Environ. Health Persp., 120, 431-436, 2012.

Misenis, C. and Zhang, Y.: An Examination of WRF/Chem: Physical Parameterizations, Nesting Options, and Grid Resolutions, Atmos. Res., 97, 315-334, 2010.

Mlawer, E. J., Taubman, S. J., Brown, P. D., Iacono, M. J., and Clough, S. A.: Radiative transfer for inhomogeneous atmospheres: RRTM, a validated correlated-k model for the longwave, J. Geophys. Res., 102, 16663-16682, 1997.

Monahan, E., Spiel, D., Davidson, K.: A model of marine aerosol generation via whitecaps and wave disruption, in: Oceanic Whitecaps, D. Reidel, Dordrecht, 167-174, 1986.

Monin, A. S. and Obukhov, A. M.: Basic laws of turbulent mixing in the surface layer of the atmosphere, Contrib. Geophys. Inst. Acad. Sci., USSR, (151), 163-187, 1954 (in Russian).

Napari, I., Noppel, M., Vehkamäki, H., and Kulmala, M.: Parameterization of ternary nucleation rates for $\mathrm{H}_{2} \mathrm{SO}_{4}-\mathrm{NH}_{3}-\mathrm{H}_{2} \mathrm{O}$ vapors, J. Geophys. Res., 107, 4381, doi:10.1029/2002JD002132, 2002.

Ng, N.L., Chhabra, P. S., Chan, A. W. H., Surratt, J. D., Kroll, J. H., Kwan, A. J., McCabe, D. C., Wennberg, P. O., Sorooshian, A., Murphy, S. M., Dalleska, N. F., Flagan, R. C., and Seinfeld, J. H.: Effect of $\mathrm{NO}_{\mathrm{x}}$ level on secondary organic aerosol (SOA) formation from the photooxidation of terpenes, Atmos. Chem. Phys., 7, 5159-5174, www.atmos-chem-phys.net/7/5159/2007/, 2007.

Pope, C. A. and Dockery, D. W.: Health effects of fine particulate air pollution: Lines that connect, Japca. J. Air. Waste Ma., 56, 709-742, 2006.

Pouliot, G. and Pierce, T. E.: Integration of the Model of Emissions of Gases and Aerosols from Nature (MEGAN) into the CMAQ Modeling System, 18th International Emission Inventory Conference, Baltimore, Maryland, 14-17 April, 2009.

Pun, B. K. and Seigneur, C.: Investigative modeling of new pathways for secondary organic aerosol formation, Atmos. Chem. Phys., 7, 2199-2216, doi:10.5194/acp-7-2199-2007, 2007.

Pun, B. K., Griffin, R. J., Seigneur, C., and Seinfeld, J. H.: Secondary organic aerosol: II. comprehensive thermodynamic module for gas/particle partitioning of molecular constituents, J. Geophys. Res., 107(D17), 4333, doi:2001D000542, 2002.

Pun, B., Seigneur, C., and Lohman, K.: Modeling secondary organic aerosol via multiphase partitioning with molecular data, Environ. Sci. Technol., 40, 4722-4731, 2006.

Real, E. and Sartelet, K.: Modeling of photolysis rates over Europe: impact on chemical gaseous species and aerosols, Atmos. Chem. Phys., 11, 1711-1727, doi:10.5194/acp-11-1711-2011, 2011.

Rao, S.T., Galmarini, S., and Puckett, K.: Air quality model evaluation international initiative (AQMEII), B. Am. Meteorol. Soc.,
92, 23-30, doi:10.1175/2010BAMS3069.1, 2011.

Roeckner, E., Brokopf, R., Esch, M., Giorgetta, M., Hagemann, S., Kornblueh, L., Manzini, E., Schlese, U., and Schulzweida, U. Sensitivity of simulated climate to horizontal and vertical resolution in the ECHAM5 Atmosphere Model, J. Climate, 19, 37713791, 2006.

Roselle, S. and Binkowski, F.: Cloud dynamics and chemistry, Technical Report, US Environmental Protection Agency, EPA/600/R-99/030 (Chapter 11), 1999.

Rosenthal, F. S., Kuisma, M., Lanki, T., Korhonen, M., Hussein, T., and Pekkanen, J.: Particulate Air Pollution Triggers Cardiac Arrest in Helsinki - Effect of Medical History and Two-pollutant Analysis, Epidemiology, 22, S53, doi:10.1097/01.ede.0000391825.03966.79, 2011.

Roy, B., Mathur, R., Gilliland, A. B., and Howard, S. C.: A comparison of CMAQ-based aerosol properties with IMPROVE, MODIS, and AERONET data, J. Geophys. Res., 112, D14301, doi:10.1029/2006JD008085, 2007.

Royer, P., Chazette, P., Sartelet, K., Zhang, Q. J., Beekmann, M., and Raut, J.-C.: Comparison of lidar-derived PM10 with regional modeling and ground-based observations in the frame of MEGAPOLI experiment, Atmos. Chem. Phys., 11, 1070510726, doi:10.5194/acp-11-10705-2011, 2011.

San José, R., Pérez, J. L., Morant, J. L., and González Barras, R. M.: The Use of Modern Third-Generation Air Quality Models (MM5-EMIMO-CMAQ) for Real-Time Operational Air Quality Impact Assessment of Industrial Plants, Water Air Soil Poll., 9, 27-37, doi:10.1007/s11267-008-9196-4, 2009.

Sartelet, K., Hayami, H., and Sportisse, B.: MICS-Asia Phase I: Model-to-data comparison for 2001, Atmos. Environ., 41, 61166131, doi:10.1016/j.atmosenv.2007.03.005, 2007.

Sartelet K., Hayami H., and Sportisse B.: MICS Asia Phase II Sensitivity to the aerosol module, Atmos. Environ., 42, 3562-3570, 2008.

Sartelet K. N., Couvidat F., Seigneur, C., and Roustan, Y.: Impact of biogenic emissions on air quality over Europe and North America, Atmos. Environ., 53, 131-141, 2012.

Schaap, M., Van Der Gon, H., Dentener, F., Visschedijk, A., Van Loon, M., ten Brink, H., Putaud, J.-P., Guillaume, B., Liousse, C., Builtjes, P.: Anthropogenic black carbon and fine aerosol distribution over Europe, J. Geophys. Res. 109, D18207, doi:10.1029/2003JD004330, 2004.

Schwede, D., Pouliot, G., and Pierce, T.: Changes to the Biogenic Emissions Inventory System version 3 (BEIS3), presentation at the 2005 Models-3 Workshop, Commun. Model. Anal. Syst., Chapel Hill, N. C., 26-28 Sept., 2005.

Shaw, P.: Application of aerosol speciation data as an in situ dust proxy for validation of the Dust Regional Atmospheric Model (DREAM), Atmos. Environ., 42, 7304-7309, 2008.

Shi, J. J., Matsui, T., Tao, W.-K., Chin, M., and Peters-Lidard, C.: Implementation of the updated Goddard longwave and shortwave radiation packages into $\mathrm{WRF}$, oral presentation at the 8th WRF Users' Workshop, 11-15 June, Boulder, CO, USA, 2007

Shrestha, K. L., Kondo, A., Maeda, C., Kaga, A., and Inoue, Y.: Numerical simulation of urban heat island using gridded urban configuration and anthropogenic heat data generated by a simplified method, Paper presented at the seventh International Conference on Urban Climate, 29 June-3 July 2009, Yokohama, Japan, 2009. 
Simpson, D., Winiwarter, W., Brjesson, G., Cinderby, S., Ferreiro, A., Guenther, A., Hewitt, C., Janson, R., Khalil, M., Owen, S., Pierce, T., Puxbaum, H., Shearer, M., Skiba, U., Steinbrecher, R., Tarrason, L., Oquist, M.: Inventorying emissions from nature in Europe, J. Geophys. Res., 104, 8113-8152, 1999.

Solazzo, E., Bianconi, R., Vautard, R., Appel, K. W., Moran, M. D., Hogrefe, C., Bessagnet, B., Brandt, J., Christensen, J. H., Chemel, C., Coll, I., Denier van der Gon, H., Ferreira, J., Forkel, R., Francis, X. V., Grell, G., Grossi, P., Hansen, A. B., Jericevic, A., Kraljevic, L., Miranda, A. I., Nopmongcol, U., Pirovano, G., Prank, M., Riccio, A., Sartelet, K. N., Schaap, M., Silver, J. D., Sokhi, R. S., Viras, J., Werhahn, J., Wolke, R., Yarwood, G., Zhang, J., Rao, S. T., and Galmarini, S.: Model evaluation and ensemble modelling of surface-level ozone in Europe and North America in the context of AQMEII, Atmos. Environ., 53, 60-74, 2012a.

Solazzo E., Bianconi R., Pirovano G., Volk M., Vautard R., Appel K.W., Bessagnet B., Brandt J., Christiansen J.H., Chemel C., Coll I., Ferreira J., Forkel R., Francis X.V., Grell G., Grossi P., Hansen A., Miranda A.I., Moran M.D., Nopmongcol U., Prank M., Sartelet K.N., Schaap M., Silver J.D., Sokhi R.S., Vira J., Werhan J., Wolke R., Yarwood G., Zhang J., Rao S.T., and Galmarini S.: Operational model evaluation for particulate matter in Europe and North America in the context of the AQMEII project, Atmos. Environ., 53, 75-92, 2012b.

Sportisse, B. and Dubois, L.: Numerical and theoretical investigation of a simplified model for the parameterization of belowcloud scavenging by falling raindrops, Atmos. Environ., 36, 5719-5727, 2002.

Spyrou, C., Mitsakou, C., Kallos, G., Louka, P., and Vlastou, G.: An improved limited area model for describing the dust cycle in the atmosphere, J. Geophys. Res., 115, D17211, doi:10.1029/2009JD013682, 2010.

Steinbrecher, R., Smiatek, G., Kble, R., Seufert, G., Theloke, J., Hauff, K., Ciccioli, P., Vautard, R., Curci, G.: Intra- and interannual variability of VOC emissions from natural and seminatural vegetation in Europe and neighbouring countries, Atmos. Environ. 43, 1380-1391, 2009.

Strader, R., Gurciullo, C., Pandis, S., Kumar, N., and Lurmann, F.: Development of gas-phase chemistry, secondary organic aerosol and aqueous-phase chemistry modules for PM modeling, Tech. rep., STI, 1998.

Stohl, A., Forster, C., Huntrieser, H., Mannstein, H., McMillan, W. W., Petzold, A., Schlager, H., and Weinzierl, B.: Aircraft measurements over Europe of an air pollution plume from Southeast Asia - aerosol and chemical characterization, Atmos. Chem. Phys., 7, 913-937, doi:10.5194/acp-7-913-2007, 2007.

Tesche, T. W., McNally, D. E., and Tremback, C.: Operational evaluation of the MM5 meteorological model over the continental United States: protocol for annual and episodic evaluation, Report prepared for the Office of Air Quality Panning and Standards, US Environmental Protection Agency, by Alpine Geophysics, LLC, Ft. Wright, KY 41017 and ATMET, LLC, Boulder, Colorado 80308, 12 July, 2002

Tie, X., Geng, F. H., Peng, L., Gao, W., and Zhao, C. S.: Measurement and modeling of O3 variability in Shanghai, China; Application of the WRF-Chem model, Atmos. Environ., 43, 42894302, 2009.
Timonen, K. L., Hoek, G., Heinrich, J., Bernard, A., Brunekreef, B., de Hartog, J., Hämeri, K., Ibald-Mulli, A., Mirme, A., Peters, A., Tiittanen, P., Kreyling, W. G., and Pekkanen, J.: Daily variation in fine and ultrafine particulate air pollution and urinary concentrations of lung Clara cell protein CC16, Occup. Environ. Med., 61, 908-914, doi:10.1136/oem.2004.012849, 2004.

Torseth, K. and Hov, O.: The EMEP monitoring strategy 2004 2009, Technical Report, EMEP/CCC, 9/2003, 2003.

Tuccella, P., Curci, G., Visconti, G., Bessagnet, B., Menut, L., and Park, R. J.: Modeling of gas and aerosol with WRF/Chem over Europe: Evaluation and sensitivity study, J. Geophys. Res., 117, D03303, doi:10.1029/2011JD016302, 2012.

Vautard, R., Moran, M. D., Solazzo, E., Gilliam, R. C., Matthias, V., Bianconi, R., Chemel, C., Ferreira, J., Geyer, B., Hansen, A. B., Jericevic, A., Prank, M., Segersm, A., Silver, J. D., Werhahn, J., Wolke, R., Rao, S.T., Galmarini, S.: Evaluation of the meteorological forcing used for the Air Quality Model Evaluation International Initiative (AQMEII) air quality simulations, Atmos. Environ., 53, 15-37, 2012.

Venkatram, A. and Pleim, J.: The electrical analogy does not apply to modeling dry deposition of particles, Atmos. Environ., 33, 3075-3076, 1999.

Vehkamäki, H., Kulmala, M., Napari, I., Lehtinen, K. E. J., Timmreck, C., Noppel, M., and Laaksonen, A.: An improved parameterization for sulfuric acid-water nucleation rates for tropospheric and stratospheric conditions, J. Geophys. Res., 107, 4622, doi:10.1029/2002JD002184, 2002.

Wang, X., Liang, X.-Z., Jianga, W.-M., Taob, Z.-N., Wang, J. X. L., Liua, H.-N., Han, Z.-W., Liu, S.-Y., Zhang, Y.-Y., Grell, G. A., and Peckham, S. E.: WRF-Chem simulation of East Asian air quality: Sensitivity to temporal and vertical emissions distributions, Atmos. Environ., 44, 660-669, doi:10.1016/j.atmosenv.2009.11.011, 2010.

Wesely, M. L.: Parameterization of surface resistance to gaseous dry deposition in regional numerical models, Atmos. Environ., 16, 1293-1304, 1989.

WHO: Health risks of particulate matter from long-range transboundary air pollution. Joint WHO / Convention Task Force on the Health Aspects of Air Pollution. WHO Regional Office for Europe, Copenhagen, 99 pp., 2006.

Wild, O., Zhu, X., and Prather, M. J.: Fast-J: Accurate simulation of in- and below cloud photolysis in tropospheric chemical models, J. Atmos. Chem., 37, 245-282, 2000.

Wong, D. C., Pleim, J., Mathur, R., Binkowski, F., Otte, T., Gilliam, R., Pouliot, G., Xiu, A., Young, J. O., and Kang, D.: WRFCMAQ two-way coupled system with aerosol feedback: software development and preliminary results, Geosci. Model. Dev., 5, 299-312, doi:10.5194/gmd-5-299-2012, 2012.

Yahya, K., Zhang, Y., and Vukovich, J. M.: Real-Time Air-Quality Forecasting over the Southeastern United States, poster presentation at the AOGS - AGU (WGPM) Joint Assembly, 13-17 August, Singapore, 2012.

Yu, S. C., Mathur, R., Pleim, J., Wong, D., Carlton, A. G., Roselle, S., and Rao, S. T.: Simulation of the indirect radiative forcing of climate due to aerosols by the two-way coupled WRF-CMAQ over the eastern United States, in Air Pollution Modeling and its Applications, edited by D. G. Steyn and S. T. Castelli, XXI, Springer Netherlands, Netherlands, C(96), 579-583, 2011. 
Yarwood, G., Rao, S., Yocke, M., and Whitten, G.: Updates to the Carbon Bond Chemical Mechanism: CB05 Final Report to the US EPA. RT-0400675, available at: http://www.camx.com/publ/ pdfs/CB05\{_\}Final\{_\}Report\{_\}120805.pdf, 2005.

Zhang, L., Gong, S., Padro, J., and Barrie, L.: A size-segregated particle dry deposition scheme for an atmospheric aerosol module, Atmos. Environ., 549-560, 2001.

Zhang, L., Brook, J. R., and Vet, R.: A revised parameterization for gaseous dry deposition in air-quality models, Atmos. Chem. Phys., 3, 2067-2082, doi:10.5194/acp-3-2067-2003, 2003.

Zhang, X. and Zhang, Y.: Application of WRF/Chem over East Asia: Evaluation, Seasonality, and Aerosol Feedbacks, poster presentation at the $11^{\text {th }}$ Annual CMAS Conference, 15-17 October, Chapel Hill, NC, 2012.

Zhang, Y.: Online-coupled meteorology and chemistry models: history, current status, and outlook, Atmos. Chem. Phys., 8, 28952932, doi:10.5194/acp-8-2895-2008, 2008.

Zhang, Y., Sartelet, K., Zhu, S., Wang, W., Wu, S.-Y., Zhang, X., Wang, K., Tran, P., Seigneur, C., and Wang, Z.-F.: Application of WRF/Chem-MADRID and WRF/Polyphemus in Europe - Part 2: Evaluation of chemical concentrations and sensitivity simulations, Atmos. Chem. Phys., 13, 6845-6875, doi:10.5194/acp-136845-2013, 2013.

Zhang, Y., Pun, B., Vijayaraghavan, K., Wu, S.-Y., Seigneur, C., Pandis, S., Jacobson, M., Nenes, A. and Seinfeld, J. H.: Development and Application of the Model of Aerosol Dynamics, Reaction, Ionization and Dissolution (MADRID), J. Geophys. Res., 109, D01202, doi:10.1029/2003JD003501, 2004.

Zhang, Y., Liu, P., Pun, B., and Seigneur, C.: A Comprehensive Performance Evaluation of MM5-CMAQ for the Summer 1999 Southern Oxidants Study Episode, Part-I. Evaluation Protocols, Databases and Meteorological Predictions, Atmos. Environ., 40, 4825-4838, 2006.

Zhang, Y., Vijayaraghavan, K., Wen, X.-Y., Snell, H. E., and Jacobson, M. Z.: Probing into regional ozone and particulate matter pollution in the United States: 1. A 1-year CMAQ simulation and evaluation using surface and satellite data, J. Geophys. Res., 114, D22304, doi:10.1029/2009JD011898, 2009.

Zhang, Y., Pan, Y., Wang, K., Fast, J. D., and Grell, G. A.: WRF/Chem-MADRID: Incorporation of an aerosol module into WRF/Chem and its initial application to the TexAQS2000 episode, J. Geophys. Res., 115, D18202, doi:10.1029/2009JD013443, 2010a.

Zhang, Y., Wen, X.-Y., and Jang, C. J.: Simulating ClimateChemistry-Aerosol-Cloud-Radiation Feedbacks in Continental US using Online-Coupled WRF/Chem, Atmos. Environ., 44(29), 3568-3582, 2010b.
Zhang, Y., Chen, Y.-S., Wu, S.-Y., Zhu, S., Sartelet, K., Tran, P., and Seigneur, C.: Application of WRF/Chem-MADRID in Europe: Model Evaluation and Aerosol-Meteorology Interactions, invited presentation at the European Geosciences Union General Assembly 2011, Vienna, Austria, 3-8 April, 2011a.

Zhang, Y., Cheng, S.-H., Chen, Y.-S., and Wang, W.-X.: Application of MM5 in China: Model Evaluation, Seasonal Variations, and Sensitivity to Horizontal Grid Resolutions, Atmos. Environ., 45, 3454-3465, 2011 b.

Zhang, Y., Chen, Y.-C., Sarwar, G., and Schere, K.: Impact of Gas-Phase Mechanisms on WRF/Chem Predictions: Mechanism Implementation and Comparative Evaluation, J. Geophys. Res., 117, D01301, doi:10.1029/2011JD015775, 2012a.

Zhang, Y., Zhang, X., Cai, C.-J., Wang, K., Fan, J.-W., Leung, R., Lim, K.-S., Zhang, G., Liu, X.-Y., Zhang, Q., and He, K.B.: Simulating Aerosol Indirect Effects with Improved AerosolCloud-Precipitation Representations in a Coupled Regional Climate Model: Model Development and Initial Application, poster presentation at the 2012 NSF/USDA/DOE Annual Earth System Modeling Project Meeting, 8-11 July, Arlington, VA, 2012b.

Zhang, Y., Karamchandani, P., Glotfelty, T., Streets, D. G., Grell, G., Nenes, A., Yu, F.-Q., and Bennartz, R.: Development and Initial Application of the Global-Through-Urban Weather Research and Forecasting Model with Chemistry (GU-WRF/Chem), J. Geophys. Res., 117, D20206, doi:10.1029/2012JD017966, 2012c.

Zhang, Y., Seigneur, C., Bocquet, M., Mallet, V., and Baklanov, A.: Real-Time Air Quality Forecasting, Part I: History, Techniques, and Current Status, Atmos. Environ., 60, 632-655, 2012d.

Zhang, Y., Seigneur, C., Bocquet, M., Mallet, V., and Baklanov, A.: Real-Time Air Quality Forecasting, Part II: State of the Science, Current Research Needs, and Future Prospects, Atmos. Environ., 60, 656-676, 2012e.

Zhang, Y., Sartelet, K., Zhu, S., Wang, W., Wu, S.-Y., Zhang, X., Wang, K., Tran, P., Seigneur, C., and Wang, Z.-F.: Application of WRF/Chem-MADRID and WRF/Polyphemus in $\mathrm{Eu}-$ rope - Part 2: Evaluation of chemical concentrations, sensitivity simulations, and aerosol-meteorology interactions, Atmos. Chem. Phys. Discuss., 13, 4059-4125, doi:10.5194/acpd-134059-2013, 2013.

Zhang, X. and Zhang, Y.: Application of WRF/Chem over East Asia: Evaluation, Seasonality, and Aerosol Feedbacks, poster presentation at the 11th Annual CMAS Conference, 15-17 October, Chapel Hill, NC, 2012.

Zhu, S. and Zhang, Y.: Sensitivity of Simulated Chemical Concentrations and Aerosol-Meteorology Interactionsto AerosolTreatments inWRF/Chem, poster presentation at the European Geosciences Union General Assembly 2011 and oral presentation at the COST Action ES1004: "EuMetChem" scientific meeting, 38 April, Vienna, Austria, 2011. 